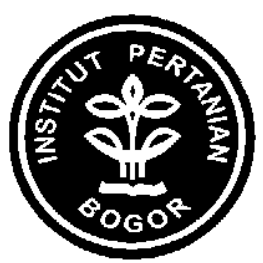




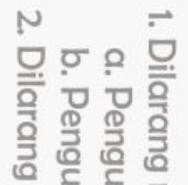

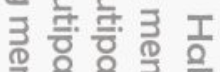

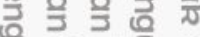

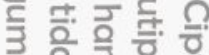

这尔造

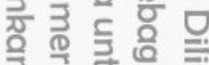

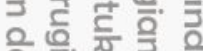

을 젱의

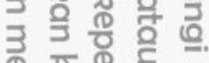

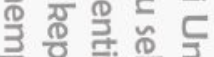

잉

공 롴을 동 을

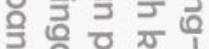

잉율 익

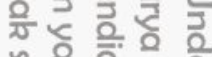

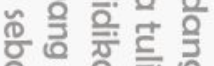

응 을

흘 응. 킁.

윽 웅

융 亩旁

๕

들

于 产

쫄 ฏ을

쟁

를

촐 을

을. 궁

을 흘 올

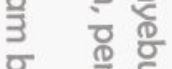

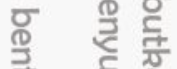

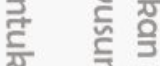

융 을

응 응 항

을

읭

흥 임

N.ㄱ: 产

ㅁํํ ํํำ

হू্ত

O

융

志

(8)

윽

흐

(อ)

공

등

흑 


\section{PERNYATAAN MENGENAI SKRIPSI DAN SUMBER INFORMASI SERTA PELIMPAHAN HAK CIPTA}

Dengan ini saya menyatakan bahwa skripsi berjudul "Penilaian Jasa Lingkungan Pohon pada Jalur Hijau Jalan sebagai Upaya Mereduksi Polusi Udara Di Kota Bogor" adalah benar karya saya dengan arahan dari dosen pembimbing dan belum diajukan dalam bentuk apa pun kepada perguruan tinggi mana pun. Sumber informasi yang berasal atau dikutip dari karya yang diterbitkan maupun tidak diterbitkan dari penulis lain telah disebutkan dalam teks dan dicantumkan dalam Daftar Pustaka di bagian akhir skripsi ini.

I Dengan ini saya melimpahkan hak cipta dari karya tulis saya kepada Inst㢈tut Pertanian Bogor.

Bogor, Januari 2017

Annes Nur Soviyanti

NIM A44110062 
Dilarang mengutip sebagian atau seluruh karya tulis ini tanpa mencatumkan atau menyebutkan sumbernya. Pengutipan hanya untuk kepentingan pendidikan, penelitian, penulisan karya tulis ilmiah, penyusunan laporan, penulisan kritik, atau tinjauan suatu masalah; dan pengutipan tersebut tidak merugikan kepentingan IPB.

Dilarang mengumumkan dan memperbannyak sebagian atau seluruh karya tulis inidalam bentuk apapun tanpa izin IPB 


\section{ABSTRAK}

ANNES NUR SOVIYANTI. Penilaian Jasa Lingkungan Pohon pada Jalur Hijau Jalan sebagai Upaya Mereduksi Polusi Udara Di Kota Bogor. Dibimbing oleh BAMBANG SULISTYANTARA.

Pohon memberikan banyak manfaat bagi lingkungan, seperti jasa lingkungan, kualitas udara, penurunan suhu di kawasan perkotaan, dan pengendali suhu iklim mikro. Peningkatan jumlah kendaraan bermotor di Kota Bogor tiap tahunnya menyebabkan peningkatan konsentrasi polutan di udara, oleh karena itu pertūnya dilakukan penelitian ini. Tujuan dari penelitian ini adalah menilai jasa lingkungan yang diberikan oleh kanopi pohon, menilai kapasitas penyimpanan karß̧on, dan memberikan rekomendasi terkait penanggulangan masalah polusi udara di Kota Bogor. Metode penelitian yang digunakan adalah pemodelan dengan menggunakan perangkat lunak CITYgreen 5.2 untuk mengetahui nilai jasa lingkungan pohon dan kapasitas cadangan karbon, kemudian metode skoring pohen yang sesuai dengan kriteria pohon penyerap polusi udara dilakukan untuk mengetahui rekomendasi pohon yang sesuai ditanam pada 10 sampel jalan penelitian. Hasil penelitian ini diharapkan dapat menjadi masukan bagi penqerintah Kota Bogor untuk penataan kawasan ruang terbuka hijau demi meñcapai Bogor sebagai "Kota Hijau". Hasil dari penelitian ini adalah nilai jasa lingkungan diberikan kanopi pohon dalam menyerap polusi udara pada 10 jalan sampel penelitian adalah $\mathrm{Rp} 233.777 .941,56$ per tahun, setelah penambahan pohon rekomendasi mengalami peningkatan menjadi Rp 259.826.601,71 per tahun, total konsentrasi polutan yang dapat diserap adalah $2.991,28 \mathrm{Kg} / \mathrm{tahun}$, meñgalami peningkatan setelah dilakukan penambahan pohon rekomendasi menjadi 3.300,15 kg/tahun, kapasitas cadangan karbon adalah 1.029,34 ton dengan kenaikan tiap tahunnya sekitar 8,011 ton/tahun, dan setelah dilakukan penämbahan pohon menjadi $1.033,17$ ton dengan kenaikan tiap tahunnya 8,012 ton/tahun, dan Pohon yang direkomendasikan untuk lebih meningkatkan efektifitas penyerapan polusi udara adalah pohon Bunga kupu-kupu (Bauhinia purpurea), Bungur (Langerstromia speciose), Cemara gembel (Cupressus papuana), Kenari (Canarium commuane), Mahoni (Swietenia mahogany), dan Pinus (Pinus merkusii), dengan jumlah pohon yang bisa ditambahkan adalah 505 pohon.

Kata kunci: Penilaian pohon, Jasa lingkungan, pemodelan CityGreen, Kanopi pohon. 


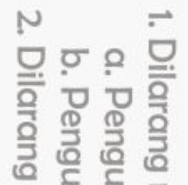

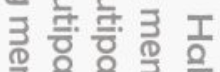

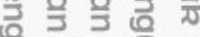

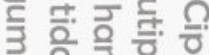

这尔造

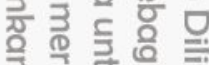

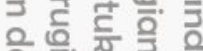

을 젱의

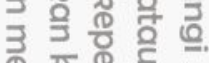

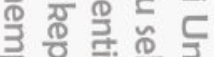

잉

공 롴을 동 을

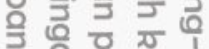

잉율 익

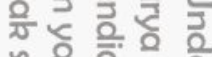

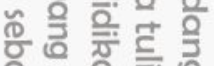

응 을

흘 응. 킁.

윽 웅

융 亩旁

๕

들

于 产

쫄 ฏ을

쟁

를

촐 을

을. 궁

을 흘 올

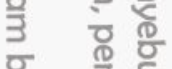

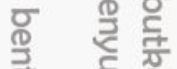

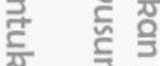

융 을

응 응 항

을

읭

흥 임

N.ㄱ: 产

ㅁํํ ํํำ

হू্ত

O

융

志

(8)

윽

흐

(อ)

공

등

흑 


\section{ABSTRACT}

ANNES NUR SOVIYANTI. The Assessment of Trees Environmental Services on Green Coridor in Order to Prevent Air Pollution in Bogor City. Supervised by BAMBANG SULISTYANTARA.

There are lots of benefits of trees for the environment, such as ecosystem services, air quality control, decreasing temperature in urban areas, and control surrounding micro climate. The annual increasment number of vehicles causes increasing concentration of air pollutants in Bogor City. The aimed of this studies were to assess values saving provides by the tree canopy, to estimate carbon storage capacity, and to give recommendation in order to Bogor City as a green City. The methods of this studies were to assess the quality of tree canopy in providing services in the urban environment by using CITYgreen 5.2 model, and to identify tree that can absorb air pollutant by using scoring methods. Result of the - study showed that the value of the savings provided by canopy to the environmental services to absorb air pollution in 10 roads study sample was Rp $233,777,941.56$ per year, after adding the recimendation trees there were increasing amount becomes $\mathrm{Rp} 259,826,601.71$ per year, the absorbent

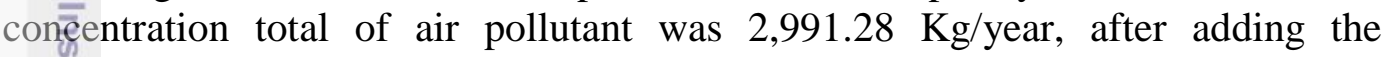
recimendation trees there were increasing amount becomes 3,300.15 kg/year, and carb̆on storage capacity was $1,029.34$ ton with increasing each year was 8.011 ton/year, after adding the recimendation trees there were increasing amount becōmes 1,033.17 with increasing each year was 8.012 ton/tahun, and for the recommendations of this studies was adding the number of trees that fit to the critêria to absorb air pollution. The recommendation of trees there were Bauhinia purpurea, Langerstromia speciose, Cupressus papuana, Canarium commuane, Swietenia mahogany, and Pinus merkusii total amount of trees that could be added to ifacreasing the effectiveness of air pollution absorbtion was 505 trees.

Keywords: Assessment of trees, Carbon storage capacity, Citygreen model, Environmental Services, Tree Canopy 


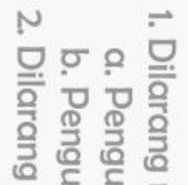

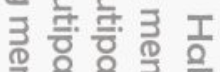

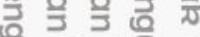

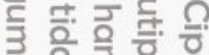

这尔造

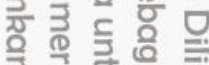

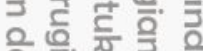

을 젱의

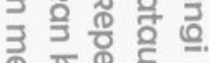

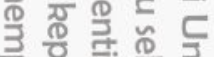

잉

공 롴을 동 을

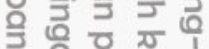

잉율 익

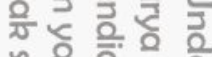

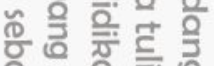

응 을

흘 응. 킁.

윽 웅

융 亩旁

๕

들

于 产

쫄 ฏ을

쟁

를

촐 을

을. 궁

을 흘 올

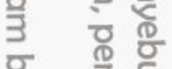

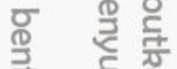

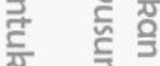

융 을

응 응 항

을

읭

흥 임

N.ㄱ: 产

ㅁํํ ํํำ

হू্ত

O

융

志

(8)

윽

흐

(อ)

공

등

흑 


\title{
PENILAIAN JASA LINGKUNGAN KANOPI POHON PADA JALUR HIJAU JALAN SEBAGAI UPAYA MEREDUKSI POLUSI UDARA DI KOTA BOGOR
}

\author{
Skripsi \\ Sebagai salah satu syarat untuk memperoleh gelar \\ Sarjana Pertanian \\ Pada \\ Departemen Arsitekrtur Lanskap \\ Fakultas Pertanian \\ Institut Pertanian Bogor
}

\author{
DEPARTEMEN ARSITEKTUR LANSKAP \\ FAKULTAS PERTANIAN \\ INSTITUT PERTANIAN BOGOR \\ BOGOR \\ 2017
}




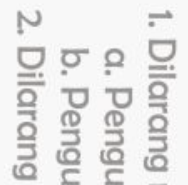

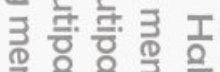

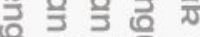

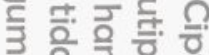

这尔造

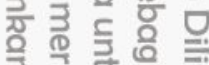

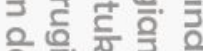

을 젱의

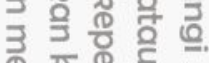

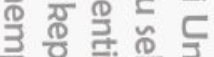

잉

공 롴을 동 을

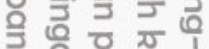

잉율 익

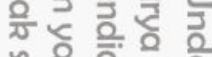

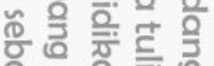

응 을

흘 응. 킁.

윽 웅

융 亩旁

๕

들

于 产

쫄 ฏ을

쟁

를

촐 을

을. 궁

을 흘 올

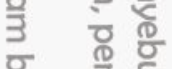

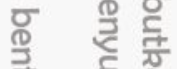

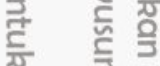

융 을

응 응 항

을

읭

흥 임

N.ㄱ: 产

ㅁํํ ํํำ

হू্ত

O

융

志

(8)

윽

흐

(อ)

공

등

흑 


\section{LEMBAR PENGESAHAN}

Judul : Penilaian Jasa Lingkungan Pohon pada Jalur Hijau Jalan sebagai Upaya Mereduksi Polusi Udara Di Kota Bogor

Nama : Annes Nur Soviyanti

NRP : A44110062

Departemen : Arsitektur Lanskap

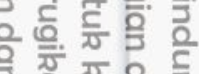

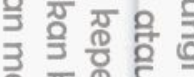

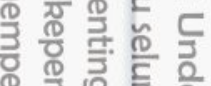

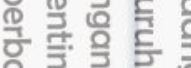

을을 잉 일

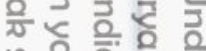

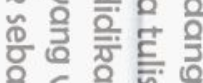

응 है 을

윽윽율

웅 孟弯

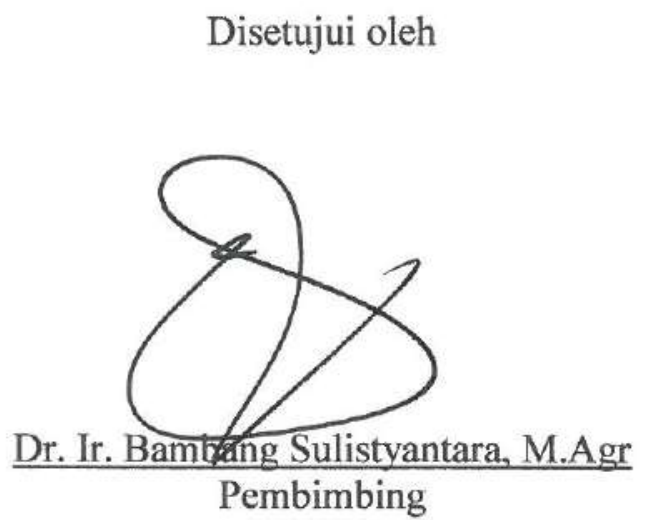

Pembimbing

Diketahui oleh

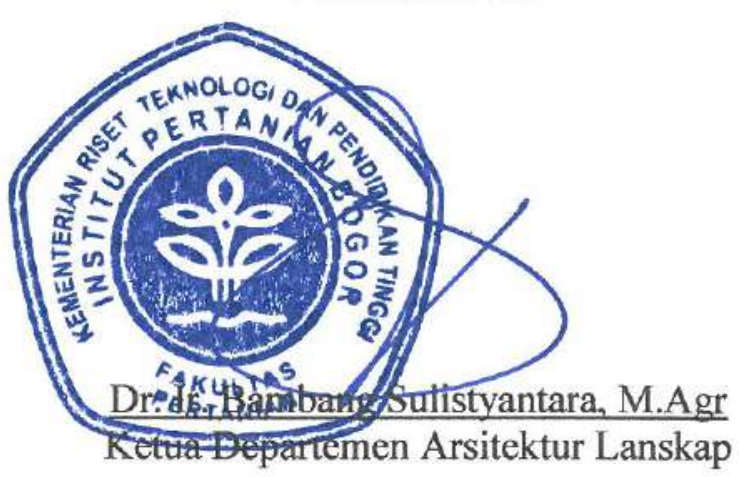

JTanggal Lulus: 25 JAN 2017 


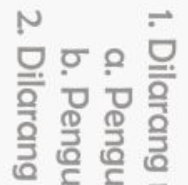

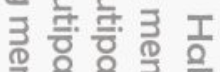

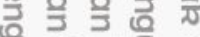

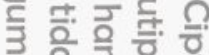

这尔造

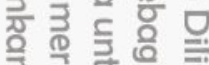

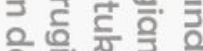

을 젱의

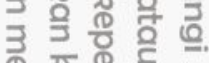

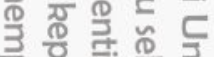

잉

공 롴을 동 을

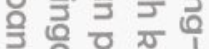

잉율 익

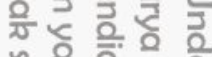

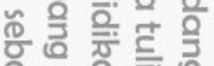

응 을

흘 응. 킁.

윽 웅

융 亩旁

๕

들

于 产

쫄 ฏ을

쟁

를

촐 을

을. 궁

을 흘 올

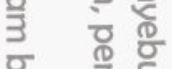

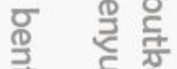

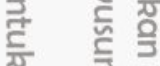

융 을

응 응 항

을

읭

흥 임

N.ㄱ: 产

ㅁํํ ํํำ

হू্ত

O

융

志

(8)

윽

흐

(อ)

공

등

흑 


\section{PRAKATA}

Puji syukur penulis panjatkan kepada Allah SWT yang senantiasa memberikan rahmat dan hidayah-Nya sehingga skripsi dengan judul "Penilaian Jasa Lingkungan Pohon pada Jalur Hijau Jalan sebagai Upaya Mereduksi Polusi Udara Di Kota Bogor" dapat diselesaikan dengan baik. Skripsi ini merupakan salah satu syarat untuk mendapat gelar Sarjana Arsitektur Lanskap yang telah dilaksanakan di Bogor, Provinsi Jawa Barat. Terima kasih penulis ucapkan kepada pihak-pihak yang terlibat dan berkontribusi dalam proses penelitian serta penyelesaian penulisan skripsi ini, yaitu kepada:

1. Dr. Ir. Bambang Sulistyantara, M.Agr. selaku pembimbing yang telah I memberikan saran dan pengarahan selama kegiatan penyusunan skripsi ini. 2. Dr. Ir. Nurhayati H.S. Arifin, M.Si. selaku dosen pembimbing akademik

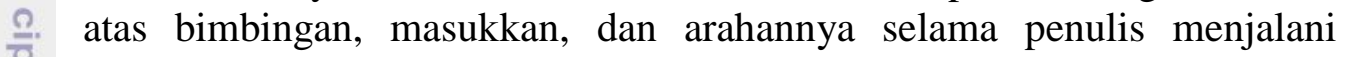
kuliah.

3. Dr. Kaswanto S.P., M.Si., dan Rezky Krisrachmansyah, S.P., M.Si. selaku dosen pembahas dalam Kolokium dan Seminar Hasil penelitian saya atas masukan, bimbingan, kritik dan saran dalam penyempurnaan skripsi ini.

4. Rezky Krisrachmansyah, S.P., M.Si dan Dr. Ir. Nizar Nasrullah, M.Agr selaku dosen penguji atas masukan, bimbingan, kritik dan saran dalam penyempurnaan skripsi ini.

. Pemerintah Daerah Jawa Barat selaku pemberi beasiswa penelitian ini, sehingga dapat mendukung terlaksananya proses penelitian ini.

6. Dinas-dinas terkait yaitu DKP, BAPEDA, dan DLLAJ Kota Bogor atas izinnya memperoleh data penelitian sehingga dapat mendukung kelancaran proses penelitian ini.

7. Bapak Ma'ruf dan Ibu Tini Suarti selaku kedua orang tua, dan kak Arif Arrahman, M. Farm, Apt atas kasih sayang, do'a dan dukungannya dalam penyususnan skripsi ini.

8. Hamzah Dhiyaul Islam, Aditya Pratama, dan Dirgha Ahdiansyah yang telah rela meluangkan waktunya membantu dalam proses pengambilan data di lapangan.

9. Terimaksih saya ucapkan kepada teman-teman seperjuangan ARL 48, 47, 46, dan 45, serta adik-adik ARL 49 yang pernah saya bimbing saat mendapatkan mata kuliah Penanaman Lanskap, dan adik-adik tersayang saya ARL 51 yang pernah saya bimbing saat mata kuliah Teknik Studio.

10. Teman-teman Sabisa Farm 2 IPB, Zainudin (AGH48), Laras (ARL 48), Faniyosi (ITSL 48), Yusep (ITSL 49), Tita (PTN 49), Ela (PTN 49), Dirgha (GFM 47), Malindo (TMB 47), Sinta (AGH 48), Prasetyo (ITK 48), Adli (EKS 49), Yessica (GFM 49) dan Iqbal (TIB 50) yang telah berjuang selama setahun kepengurusan membangun, mengelola, dan merawat kebun Sabisa Farm IPB.

Penulis berharap semoga penelitian ini dapat bermanfaat untuk berbagai pihak yang memerlukan dan bermanfaat sebagai referensi bagi penelitian lain yang dilaksanakan pada masa yang akan datang. 


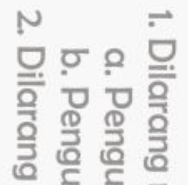

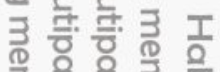

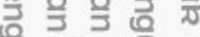

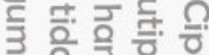

这尔造

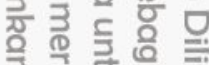

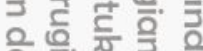

을 젱의

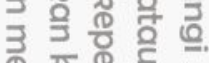

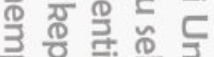

잉

공 롴을 동 을

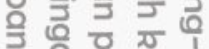

잉율 익

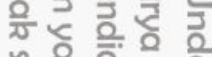

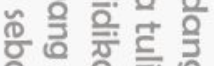

응 을

흘 응. 킁.

윽 웅

융 亩旁

๕

들

于 产

쫄 ฏ을

쟁

를

촐 을

을. 궁

을 흘 올

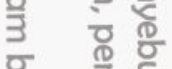

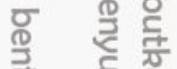

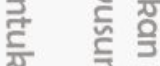

융 을

응 응 항

을

읭

흥 임

N.ㄱ: 产

ㅁํํ ํํำ

হू্ত

O

융

志

(8)

윽

흐

(อ)

공

등

흑 


\section{DAFTAR ISI}

DAFTAR ISI ............................................................................................ xiii

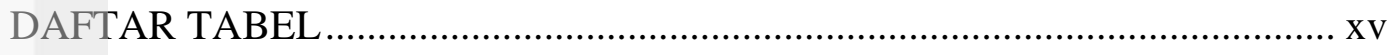

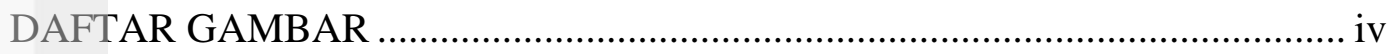

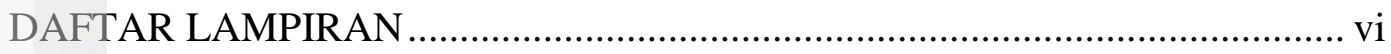

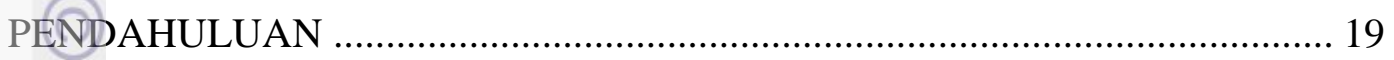

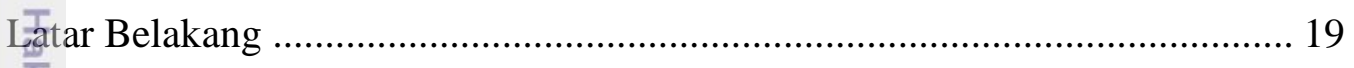

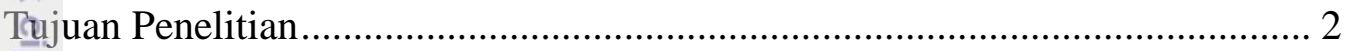

Manfaat Penelitian ....................................................................................... 2

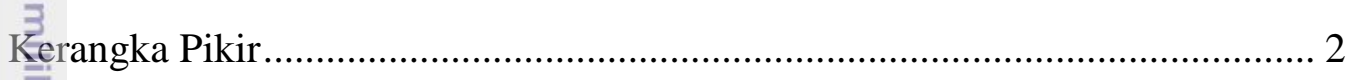

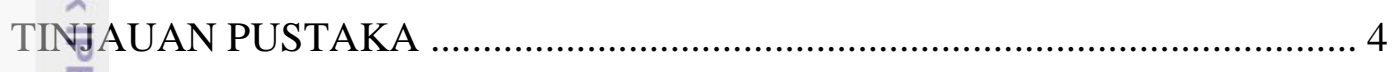

Karakter Fisik Pohon .................................................................................. 4

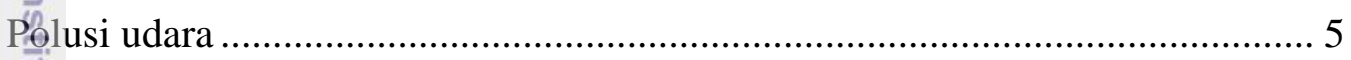

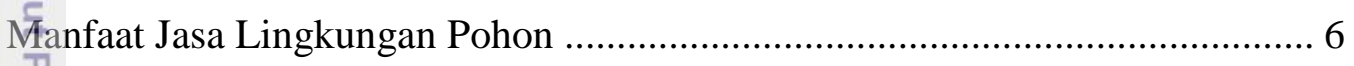

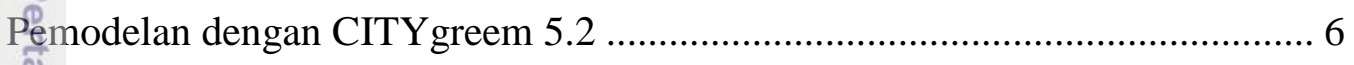

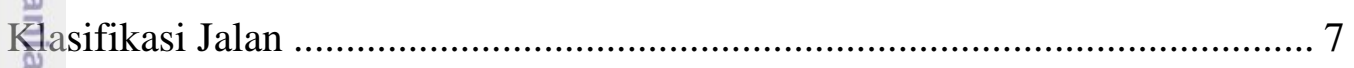

Struktur Kawasan perkotaan dan sistem jaringan jalan sekunder................... 9

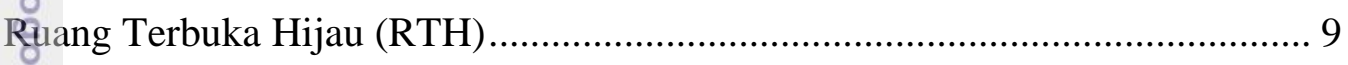

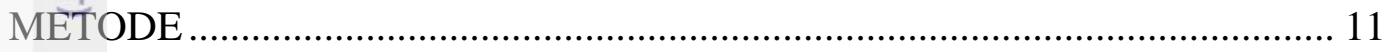

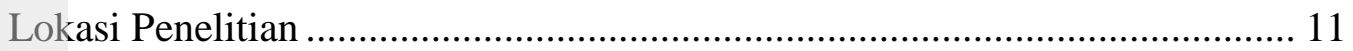

Waktu Penelitian ..................................................................................... 12

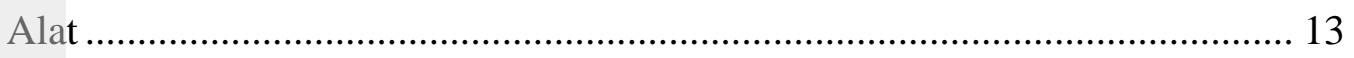

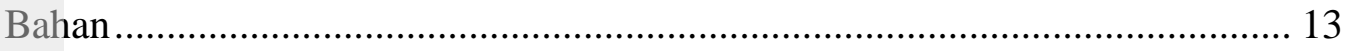

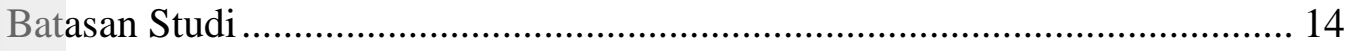

Metode Penilaian Jasa Lingkungan ........................................................... 14

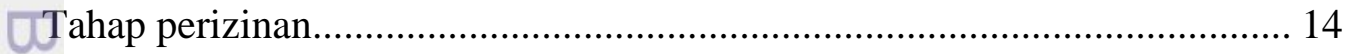

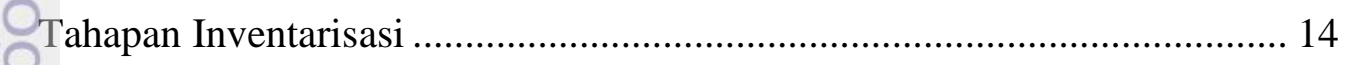

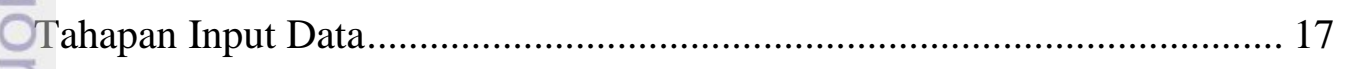

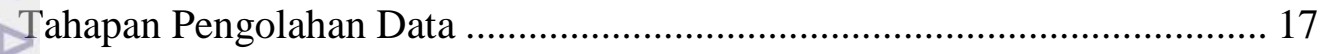

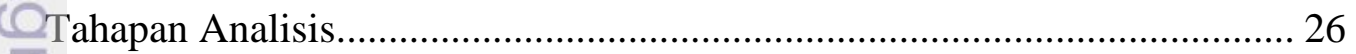




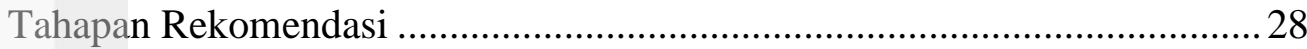

Metode Skor Pohon Pereduksi Polusi Udara .................................................... 28

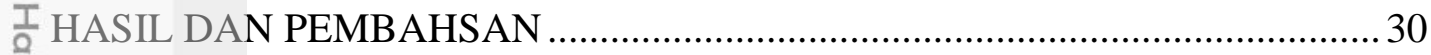

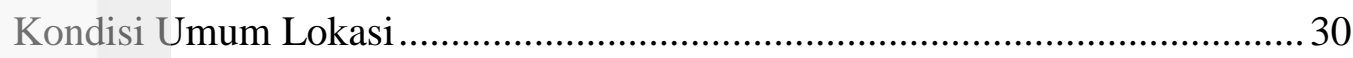

Kondisi jalan dan transportasi di Kota Bogor.................................................. 33

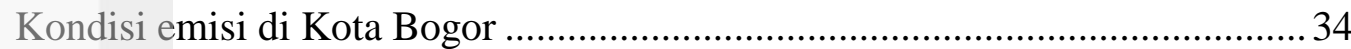

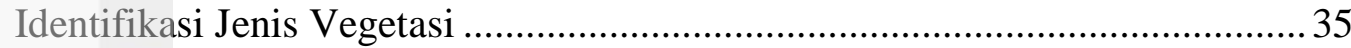

Identifikasi pohon pada Jl. Jendral Sudirman .............................................. 36

Identifikasi pohon pada J1. R. E. Martadinata ............................................... 36

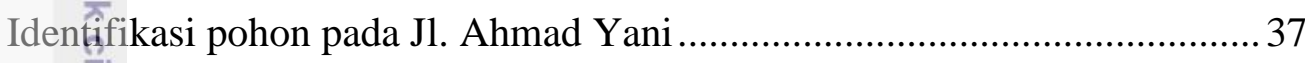

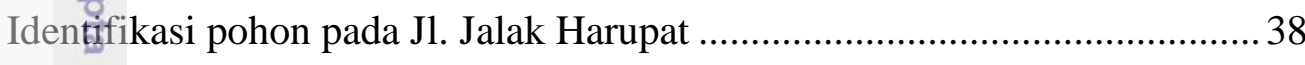

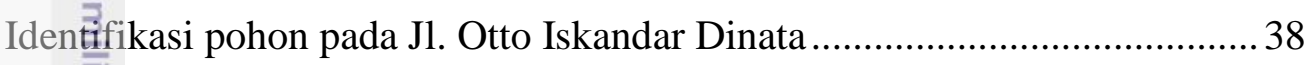

Identifikasi pohon pada J1. Ir. H. Djuanda ..................................................... 39

Identifikasi pohon pada Jl. Raya Empang .................................................... 39

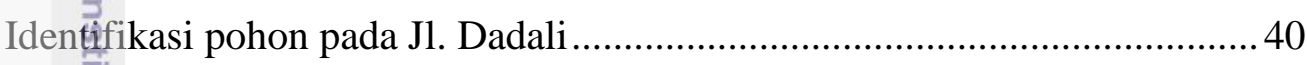

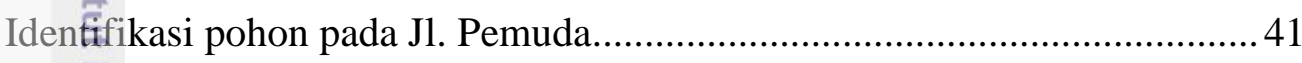

Identifikasi pohon pada Jl. Raya Pajajaran ................................................ 41

Identifikasi Luas Penutupan Kawasan Awal ................................................... 42

Analisis Kualitas Udara ............................................................................. 43

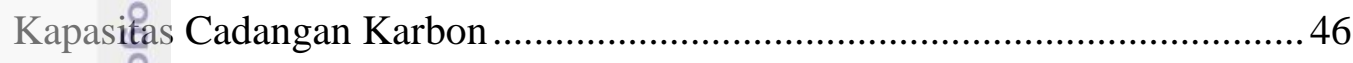

Nilai Pengurangan Polusi Udara .................................................................. 46

Pohon Penyerap Polusi Udara dalam Bentuk Gas ........................................... 47

Pohon Penyerap Polusi Udara dalam Bentuk Partikel....................................... 49

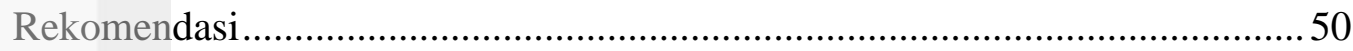

Hasil Analisa Setelah Penambahan Vegetasi Rekomendasi ............................51

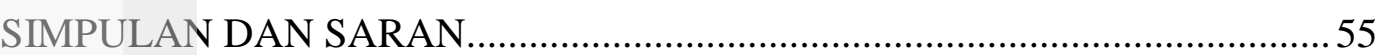

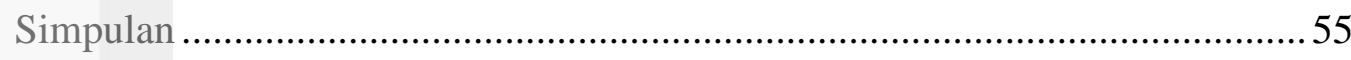

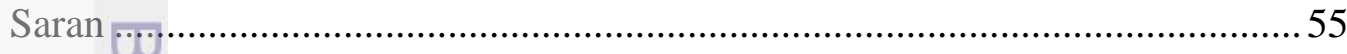

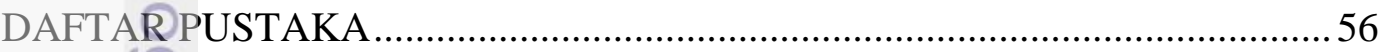

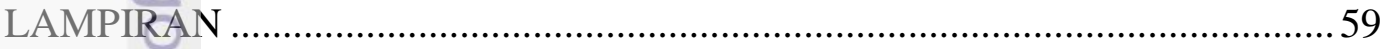

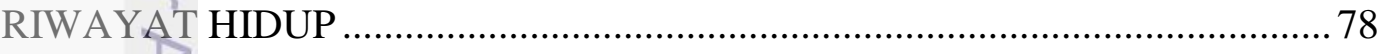




\section{DAFTAR TABEL}

Tabel 1 Hubungan antara kawasan perkotaan dengan peranan ruas jalan dalam sistem jaringan jalan sekunder.

Tabel 2 Kriteria penentuan lokasi penelitian................................................... 12

Tabel 3 Tabel jadwal kegiatan penelitian ..................................................... 12

Tabel 4 Tabel Keperluan peralatan yang digunakan dalam penelitian ............ 13

Tabel 5 Bahan yang diperlukan dalam penelitian ........................................... 13

Tabel 6 Kriteria pohon yang diteliti pada penelitian ini................................ 14

Tabel 7 Kriteria kelas kesehatan pohon, kelas pertumbuhan pohon, dan

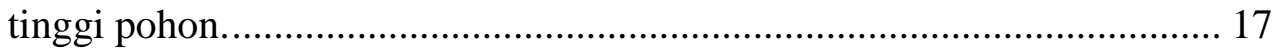

Fabel 8 Kriteria umum dan khusus pohon pereduksi polusi .......................... 28

Tैabel 9 Daftar 10 jalan sampel penelitian di Kota Bogor ................................ 30

Tabel 10 Kondisi emisi rata-rata tahun 2011-2014 di Kota Bogor .................. 35

Tabel 11 Rekapitulasi jumlah pohon yang diamati pada 10 sampel jalan

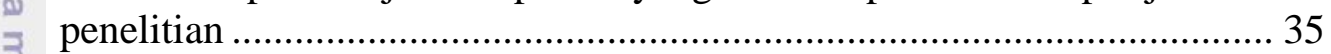

Pabel 12 Presentase jumlah pohon pada Jl. Jendral Sudirman.......................... 36

Tabel 13 Presentase jumlah pohon pada J1. R.E. Martadinata ......................... 37

Tabel 14 Presentase jumlah pohon pada Jl. Jendral Ahmad Yani..................... 37

Tabel 15 Presentase jumlah pohon pada Jl. Jalak Harupat............................... 38

Tabel 16 Presentase jumlah pohon pada Jl. Otto Iskandar Dinata ................... 38

Fabel 17 Presentase jumlah pohon pada J1. Ir. H. Djuanda.............................. 39

Fabel 18 Presentase jumlah pohon pada Jl. Raya Empang ............................ 40

Tabel 19 Presentase jumlah pohon pada Jl. Dadali ........................................... 40

Tabel 20 Presentase jumlah pohon pada Jl. Pemuda........................................ 41

Tabel 21 Presentase jumlah pohon pada Jl. Raya Pajajaran............................ 42

Eabel 22 Tabel komposisi luas penutupan kawasan penelitian....................... 43

Tabel 23 Manfaat cadangan karbon ............................................................. 46

Tabel 24 Daftar presentase kesesuaian pohon penyerap polusi gas ................. 48

Aabel 25 Daftar presentase kesesuaian pohon penyerap polusi partikel .......... 49

Tabel 26 Rekomendasi tanaman pada 10 jalan sampel penelitian .................. 50

Tabel 27 Rekapitulasi komposisi penutupan lahan setelah penambahan

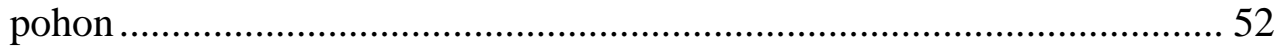

Tabel 28 Rekapitulasi kapasitas cadangan karbon setelah penambahan pohon

Tabel 29 Perbandingan Nilai Manfaat Ekonomi Sebelum dan Sesudah

Penambahan Pohon Rekomendasi

Tabel 30 Nilai Reduksi Polutan Sebelum dan Sesudah Penambahan

Pohon Rekomendasi 


\section{DAFTAR GAMBAR}

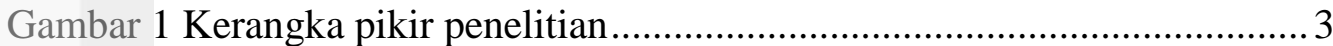

Gambar 2 Bentuk kanopi/tajuk pohon (Sumber: Booth 1983) ........................... 5

Gambar 3 Bentuk percabangan pohon (Sumber: Stevens et al. 1994) ...............5

Gambar 4 Logo American Forest (Kiri) dan perangkat lunak CITYgreen

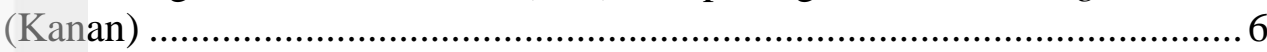

Gambar 5 Penampang potongan melintang jalan arteri sekunder yang dipisahkan oleh median jalan................................................................. 8

Gambar 6 Penampang potongan melintang jalan arteri sekunder tanpa

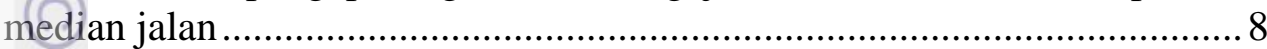

Gambar 7 Lokasi penelitian di Kota Bogor, Provinsi Jawa Barat, Indonesia.....

Gambâr 8 Teknik pengambilan data diameter pohon setinggi dada pada pohion dengan batang utama bercabang. 16

Gambar 9 Teknik pengambilan data diameter pohon setinggi dada pada pothon dengan batang utama beragam bentuk .......................................... 16

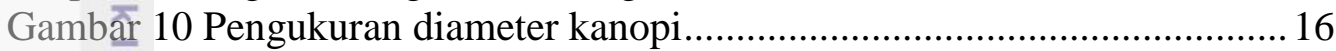

Gambar 11 Foto pohon yang menggambarkan seluruh bagian pohon dari atas hingga ke bawah ......................................................................... 17

Gambar 12 Jendela ArcView 3.3 untuk membuka jendela View baru............. 18

Gambar 13 Jendela Extention pada ArcView 3.3 ….......................................... 18

Gambar 14 Jendela Add Theme untuk membuka file dengan tipe ekstensi img

Gambar 15 Jendela Add Theme untuk membuka file dengan tipe ekstensi

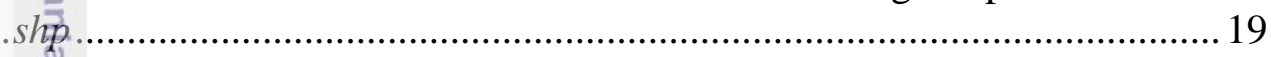

Gambar 16 Proses mangaktifkan theme pada CITYgreen ...............................2 20

Gambar 17 Add/update data untuk landcover urban ......................................2 21

Gambar 18 Add/update data untuk landcover imperviouse ............................21

Gambar 19 Add/update data untuk landcover trees .........................................22

Gambar 20 Data atribut pada vegetasi theme ................................................22

Gambar 21 Perintah memperoleh analisa data dengan CITYgreen 5.2 ........... 23

Gambar 22 Kriteria yang perlu diisikan pada jendela CITYgreen

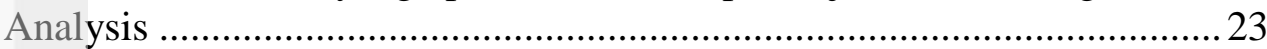

Gambar 23 Kriteria yang perlu diisika pada jendela CITYgreen

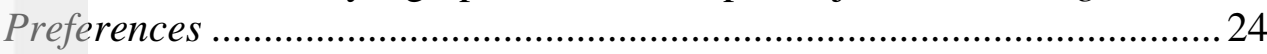

Gambar 24 Jendela analysis area name field untuk memilih field yang dimasukan dalam analisis data....................................................................2. 25

Gambar 25 Proses Run Analysis Data pada CITYgreen ..................................225

Gambar 26 Contoh hasil CITYgreen Analysis report summary ....................... 26

Gambar 27 Presentase jenis kendaraan bermotor (Kiri) dan jumlah kendaraan bermotor di Kota Bogor (Kanan) .......................................... 33

Gambar 28 Diagram uji emisi kendaraan bermotor yang menggunakan bensin (atas), dan solar (bawah) di Kota Bogor........................................... 34

Gambar 29 Diagram Rekapitulasi Jumlah Pohon pada 10 Sampel Jalan

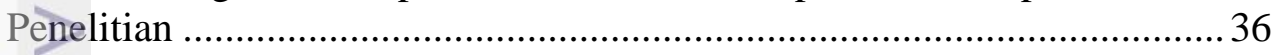

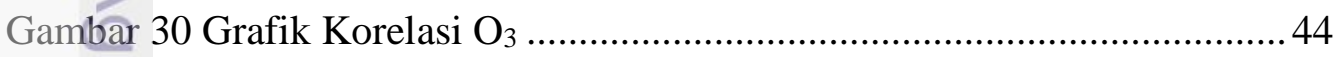




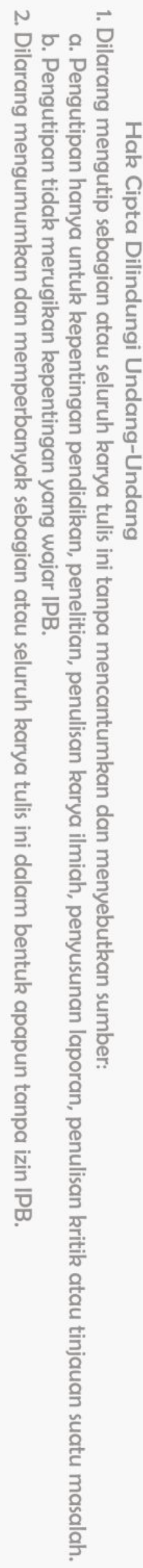

Gambar 31 Grafik Korelasi $\mathrm{SO}_{2}$ 44

Gambar 32 Grafik Korelasi Polutan CO 45

Gambar 33 Grafik Korelasi Polutan Partikel (PM10) 45

Gambar 34 Diagram manfaat pengurangan polusi udara dan manfaat ekonomi 
Lampiran 1 Hasil analisa CITYgreen pada Jl. Jalak Harupat..........................59

Lampiran 2 Hasil analisa CITYgreen pada Jl. Dadali ......................................6 60

Lampiran 3 Hasil analisa CITYgreen pada Jl. Ir. H. Djuanda ...........................61 61

Lampiran 4 Hasil analisa CITYgreen pada Jl. Raya Raya Empang .................6 62

Lampiran 5 Hasil analisa CITYgreen pada Jl. Jend. Ahmad Yani ....................6 63

Lampiran 6 Hasil analisa CITYgreen pada Jl. Otto Iskandar Dinata ............... 64

Lampiran 7 Hasil analisa CITYgreen pada Jl. Raya Raya Pajajaran.................6 65

Lampiran 8 Hasil analisa CITYgreen pada Jl. Pemuda .....................................66 66

Lampiran 9 Hasil analisa CITYgreen pada Jl. R. E. Martadinata .....................6 67

Lampiran 10 Hasil analisa CITYgreen pada J1. Jend. Sudirman .......................68 68

Lampifan 11 Daftar kode nama jalan sampel penelitian ............................... 71

Lampipan 12 Daftar kode nama lokal pohon sampel penelitian ....................... 72

Lampiran 13 Peta lokasi penambahan vegetasi pada J1. Jalak Harupat ............ 67

Lampifan 14 Peta lokasi penambahan vegetasi pada Jl. Dadali .......................6 68

Lampiran 15 Peta lokasi penambahan vegetasi pada J1. Ir. H. Djuanda........... 69

Lampiř 16 Peta lokasi penambahan vegetasi pada J1. Raya Empang ........... 70

Lampiran 17 Peta lokasi penambahan vegetasi pada Jl. Jendral Ahmad

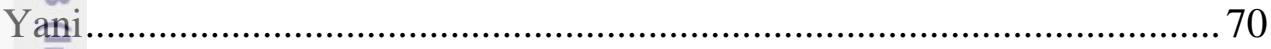

Lampi]̄an 18 Peta lokasi penambahan vegetasi pada Jl. Otto Iskandar

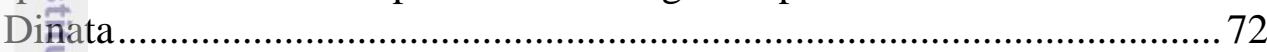

Lampiran 19 Peta lokasi penambahan vegetasi pada Jl. Pemuda .................... 73

Lampixan 20 Peta lokasi penambahan vegetasi pada Jl. R.E. Martadinata ...... 74

Lampiran 21 Peta lokasi penambahan vegetasi pada Jl. Jendral Sudirman...... 75

Lampiran 22 Peta lokasi penambahan vegetasi pada Jl. Pajajaran Segmen

1 tan 2

Lampiran 23 Peta lokasi penambahan vegetasi pada Jl. Pajajaran Segmen

3 dan 4. 


\section{PENDAHULUAN}

\section{Latar Belakang}

Secara geografis Kota Bogor terletak di antara 106' 48' BT dan 6' 26' LS, kedudukan geografis Kota Bogor di tengah-tengah wilayah Kabupaten Bogor serta lokasinya sangat dekat dengan Ibukota Negara, merupakan potensi yang strategis bagi perkembangan dan pertumbuhan ekonomi dan jasa, pusat kegiatan nasional untuk industri, perdagangan, transportasi, komunikasi, dan pariwisata. (BPLH 2015). Kota Bogor menjadi salah satu akses utama menuju ke Kota Jakărta, oleh karena itu banyaknya volume kendaraan yang melintasi jalan-jalan di Ko $\overline{\text { Ea }}$ Bogor memberikan dampak baik positif yaitu pertumbuhan perekonomian kotå melaju pesat, maupun dampak negatif yaitu ketidakteraturan transportasi yang diakibatkan jumlah kendaraan meningkat tiap tahunnya, pada tahun 2013 kendaraan bermotor di Kota Bogor berjumlah 357.102 unit, dan pada tahun 2014

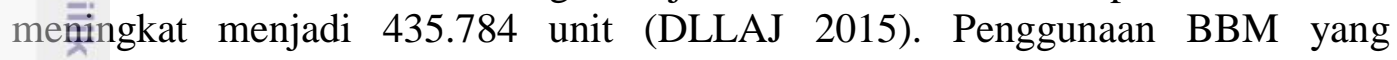
menjingkat konsumsi BBM didominasi oleh kendaraan bermotor beroda dua (sepeda motor) yang mencapai lebih dari 75\% (DLLAJ 2015) memberikan efek meñingkatnya emisi polusi udara, peningkatan suhu perkotaan akibat efek rumah kacâ.

Salah satu upaya pemerintah menurunkan suhu perkotaan dengan menanam pohen. Pohon sendiri merupakan elemen soft materials yang terdapat pada lanskap (Lestari 2011). Pohon memiliki banyak manfaat salah satunya adalah mañfaat kanopi pohon dalam kehidupan di perkotaan. Kanopi pohon memiliki banyak manfaat salah satunya menangkap partikel polutan dan mengurangi konsentrasi polutan di udara (Beckett et al. 1998). Selain itu, peran kanopi pohon adatah sebagai pengontrol suhu sekitarnya, yaitu menurunkan suhu kawasan sekifarnya. (Nowak et al. 2006)

Jasa lingkungan pohon terhadap lingkungan sekitar sangatlah besar, terutama dalam menanggulangi urban heat island yaitu peningkatan suhu perkotaan akibat kurangnya ruang terbuka hijau. Jasa lingkungan sendiri didefinisikan sebagai jasa yang diberikan oleh fungsi ekosistem alam maupun buatan yang nilai dan manfaatnya dapat dirasakan secara langsung (tangible) maupun tidak langsung (intangible) oleh stakeholder dalam rangka membantu memelihara dan meningkatkan kualitas lingkungan dan kehidupan masyarakat dalam mewujudkan pengelolaan ekosistem secara berkelanjutan meliputi antara lain jasa wisata alam, jasa perlindungan tata air, kesuburan tanah, pengendalian erosi dan banjir, keindahan, keunikan, penyerapan dan penyimpanan karbon (carbon offset) (Agus et al. 2012).

Wungsi ekologis pohon pada lingkungan yaitu mampu menyerap partikel dan polutan gas, sehingga mampu memperbaiki kualitas udara. Tanaman dapat mengurangi polutan udara dengan proses oksigenisasi. Tanaman menghasilkan oksigen, sehingga polutan udara yang melewati sekitar tanaman akan mengalami proses pencampuran antara oksigen dengan polutan sehingga membuat udara di sekitar tanaman menjadi bersih. Tanaman merupakan penyaring udara yang 
mampu menyerap gas polutan seperti $\mathrm{SO}_{2}$ dan $\mathrm{HF}$ serta polutan lain di udara dalam jumlah tertentu tanpa memperlihatkan efek kerusakan (Grey et al. 1978)

Kontribusi pohon dalam upaya peningkatan kualitas kesehatan dan jasa I lingkungan sangat besar. Untuk mengetahui nilai jasa lingkungan pohon, dalam meredusi polusi udara dapat digunakan metode GIS dengan perangkat lunak ArcView 3.2 ekstensi CITYgreen 5.2, dimana kemampuan pohon dalam mereduksi polusi udara dianalisis dengan pendekatan dimensi fisik pohon. CITYgreen 5.2 mampu menganalisis kualitas udara, penyimpanan cadangan karbon, dan pemodelan pertumbuhan kanopi pohon. Oleh karena itu penelitian ini akan menggunakan metode pemodelan oleh software CITYgreen 5.2 untuk mengetahui - nilai jasa tingkungan pohon yaitu penilaian kulaitas udara, penyimpanan cadangan karbon kota, dan pemodelan pertumbuhan vegetasi 10 tahun yang akan datang sebagai perbandingan dan pertimbangan dalam perencanaan tata hijau perkotaan.

닌

\section{Tujuan Penelitian}

Tujuan penelitan ini adalah sebagai berikut:

1. Menitai jasa lingkungan pohon dalam menyerap polusi udara di Kota Bogor,

2. Memperkirakan kapasitas penyimpanan karbon di Kota Bogor, dan

3. Membrat rekomendasi tata hijau terkait penanggulangan polusi udara di Kota Bogor.

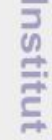

\section{Manfaat Penelitian}

Mănfaat yang diharapkan dari kegiatan penelitian ini yaitu menghasilkan rekomenđasi yang dapat menjadi acuan bagi pemerintah daerah dan pihak terkait dalam penenerapan tata hijau khususnya dalam pemilihan fungsi pohon yang sesuai digunakañ dalam penataan lanskap.

\section{Kerangka Pikir}

Kota Bogor merupakan kota yang strategis karena berdekatan dengan Ibu Kota Negara yaitu Jakarta, dan memberikan dampak positif yaitu pertumbuhan perekonomian dan infrastruktur, namun dapat memberikan dampak negatif yaitu peningkatan jumlah kendaraan yang menyebabkan penggunaan konsumsi BBM meningkat dan memberikan implikasi pada peningkatan konsentrasi polutan di udara. Solusi pemecahan masalah tersebut sangat diperlukan, sehingga perlunya dilakukan penelitian ini.

Penelitian ini menggunakan data-data yang diambil dari survei lapang (lokasi pohon, kondisi fisik pohon, spesies pohon, dan dokumentasi foto) dan studi pustaka (peta dasar, klimatologi, kondisi transportasi, dan kondisi polusi udara) yang nantinya akan di-input dengan menggunakan dua metode. Metode pertama menggunakan perangkat lunak ArcView 9.3 untuk dilakukan training area dengan tujuan memisahkan jenis penutupan lahan (canopy dan non-canopy), kemudian hasilnya akan dilakukan analisis menggunakan perangkat lunak ArcView 3.3 ekstensi CITYgreen 5.2 dengan target yang ingin dicapai adalah memperoleh kemampuan jerapan polusi udara, kapasitas cadangan karbon, dan biaya penghematan yang dapat dilakukan oleh kanopi pohon. Kemudian hasil rekapitulași dari data analisa CITYgreen pada 10 sampel jalan penelitian akan 
dilakukan proses analisis korelasi untuk mengetahui hubungan variable yang terlibat.

Metode lainnya yang digunakan dalam penelitian ini adalah metode skoring kriteria pohon penyerap polusi udara. Target yang ingin dicapai dari metode ini adalah mengetahui pohon mana saja yang sesuai sebagai pohon penyerap polusi udara dalam bentuk gas dan penjerap polusi dalam bentuk partikel. Kemudian pohon yang sesuai dengan kriteria dapat menjadi pertimbangan untuk dilakukan penambahan jumlah spesies pada jalur hijau jalan serta lokasi yang sesuai dilakukan penanaman pohon rekomendasi. Hasil akhir yang dicapai dalam penelitian ini adalah nilai-nilai jasa lingkungan yang akan dijadikan sebagai acuan dalan pembuatan rekomendasi. Untuk lebih jelasnya mengenai kerangka pikir penelitian disajikan pada Gambar 1 berikut ini.

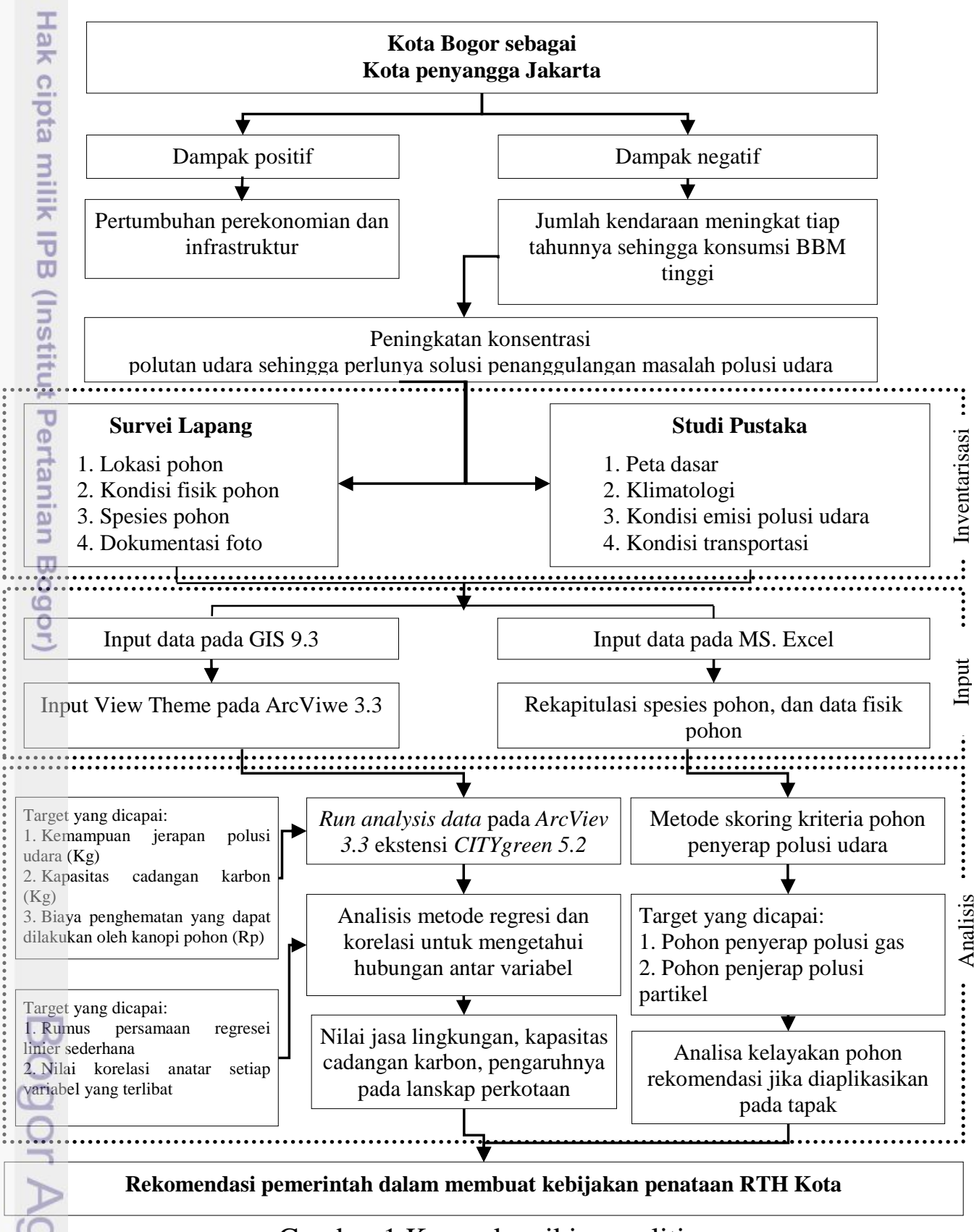

Gambar 1 Kerangka pikir penelitian 


\section{TINJAUAN PUSTAKA}

\section{Karakter Fisik Pohon}

Pohon adalah tanaman dengan batang berkayu, berakar dalam, dan memiliki percabangan jauh dari tanah serta tinggi lebih dari 3 meter (Hakim dan Utomo 2003). Menurut Direktorat Jenderal Bina Marga (2010), pohon adalah semua tumbuhan dengan batang dan cabang yang berkayu. Pohon memiliki . batang utama yang tumbuh tegak dan menopang tajuk pohon. Pohon berdasarkan $\subsetneq$ ketinggiannya dibedakan atas pohon rendah, pohon sedang, dan pohon tinggi. Pohon rendah ialah pohon yang tingginya kurang dari $6 \mathrm{~m}$; pohon sedang adalah pohon yâng memilki ketinggian antara 6 - $12 \mathrm{~m}$; sedangkan pohon tinggi ialah pohon yang ketinggiannya mencapai lebih dari $12 \mathrm{~m}$ (Bridwell 2003). Pembagian jenis pohön ini berdasarkan pada tinggi dan lebar pohon ketika sudah mencapai usia dewasa.

Secara morfologi, bagian-bagian tubuh pohon meliputi akar, batang, cabang, dăun, ranting, bunga, dan buah. Bentuk pohon merupakan elemen desain yang paling memegang peranan dan harus dipertimbangkan dalam membuat perancangan lanskap (Booth 1983). Dalam hal ini, bentuk pohon adalah tajuk atau keseluruhăn bentuk dan kelebaran maksimal tertentu dari ranting dan daun pohon tersebut (Đirektorat Jenderal Bina Marga 1996). Secara umum, pohon merupakan elemen uttama yang secara individu atau berkelompok penampilannya dapat mempengăgruhi penampakan visual dan memberikan kesan yang berbeda-beda dari jarak penḡamatan berbeda di dalam lanskap (Carpenter et al. 1975). Ketika dalam suatu tapäk menggunakan pohon dengan berbagai bentuk tajuk yang terlalu beragam maka justru akan menimbulkan kebingungan dan mengurangi keindahan lanskap itu sendiri.

Setiap jenis pohon memiliki bentuk arsitektur yang berbeda satu sama lain sesuai dengan jenisnya. Bentuk tajuk pohon adalah elemen utama yang menentukan bentuk arsitektur suatu pohon. Selain bentuk tajuk, bentuk percabangan pohon itu sendiri juga menjadi elemen pendukung dalam membentuk arsitektur suatu pohon. Percabangan pohon yang bervariasi dengan karakter yang unik dapat menghasilkan bentuk arsitektural pohon yang bisa dimanfaatkan sebagai focal point di dalam tapak dan dapat menunjang karakter lanskap tertentu. Beberapa bentuk tajuk dan percabangan pohon ditampilkan pada Gambar 2 dan Gambar 3.

Bunga adalah bagian yang sangat populer dalam identifikasi dan pemilihan pohon. Masa pembungaan yang hanya berlangsung sekali atau beberapa kali dalam setahun mempengaruhi keindahan pohon karena tidak bisa dinikmati sepanjang waktu. Keberadaan buah dipengaruhi oleh munculnya bunga pada pohon, sehingga juga hanya bisa dilihat di saat-saat tertentu. Keberadaan buah dalam suatu lanskap tidak terlihat secara signifikan dan tidak ornamental, tetapi buah mempengaruhi kehadiran burung di pohon tersebut (Bridwell 2003). 


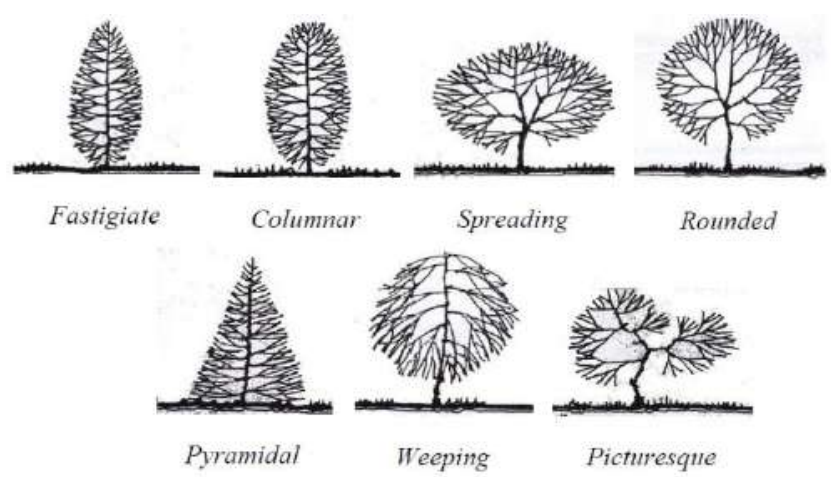

Gambar 2 Bentuk kanopi/tajuk pohon

(Sumber: Booth 1983)

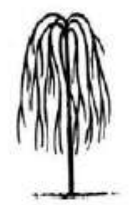

Weeping

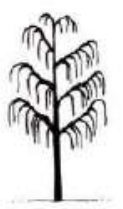

Pendulous

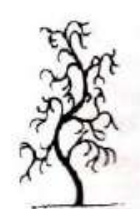

Tortuous

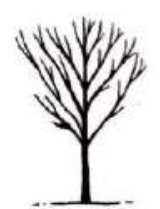

Vertical

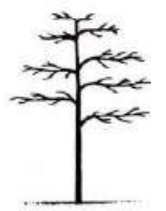

Horizontal

Gambar 3 Bentuk percabangan pohon

(Sumber: Stevens et al. 1994)

\section{Polusi udara}

Menurut M.N. Rao dalam bukunya yang berjudul "Air Pollution", polusi udara adalah suatu zat yang mengkontaminasi udara sehingga menurunkan kualitas dan menimbulkan dampak negatif bagi makhluk hidup. Saat ini telah banyak penelitian yang menunjukan bahwa telah menigkatnya konsentrasi polusi di udara. Hal ini mengakibatkan peningkatan suhu di permukaan bumi yang biasa kita kenal dengan efek rumah kaca. Telah diperkirakan sebelumnya bahwa peningkatan konsentrasi $\mathrm{CO}_{2}$ (Karbon dioksida) di udara meningkatkan suhu bumi $4^{\circ} \mathrm{C}$ lebih tinggi tiap lima dekadenya, sehingga mencairnya kutub yang mengakibatkan volume air meningkat dan banyak terjadi banjir.

Polutan udara diklasifikasikan dalam 3 tipe, yaitu natural kontaminan (serbuk polen bunga, bakteri, dan debu vulkanik), tipe partikel aerosol (debu, asap, dan embun). dan tipe vaporasi gas yaitu gas sulfur $\left(\mathrm{SO}_{2}, \mathrm{SO}_{3}\right.$, dan $\left.\mathrm{H}_{2} \mathrm{~S}\right)$, gas nitrogen $\left(\mathrm{NO}, \mathrm{NO}_{2}\right.$, dan $\left.\mathrm{NH}_{3}\right)$, gas oksigan $\left(\mathrm{O}_{3}, \mathrm{CO}\right.$, dan $\left.\mathrm{CO}_{2}\right)$, gas halogen $(\mathrm{HF}$ dan $\mathrm{HCl}$ ), gas organic (Adlehid dan hidrokarbon), dan gas radioaktif.

Tipe kontaminasi polutan alami terjadi secara alamiah karena proses biologis tanaman atau kejadian alami seperti menyebarnya debu vulkanik akibat aktifitas vulkanis gunung. Ukuran polutan alami antara 10-50 $\mu$ (Mikron). Tipe kontaminan Aerosol yaitu dispersi dari padatan atau cairan yang partikelnya mikroskopis pada media gas seperti debu, asap dan embun. Ukuran partikel debu 20-200 $\mu$ (Mikron), partikel asap berukuran 0.2-0.01 $\mu$ (Mikron), dan embun sekitar 40-500 $\mu$ (Mikron). Sedangkan Tipe kontaminan gas biasanya berasal dari hasil pembakaran senyawa karbon baik industrial, gas buang trasportasi, maupun rumah tangga. 


\section{Manfaat Jasa Lingkungan Pohon}

Jasa lingkungan diartikan sebagai keseluruhan konsep sistem alami yang I menyediakan aliran barang dan jasa yang bermanfaat bagi manusia dan J lingkungan yang dihasilkan oleh proses ekosistem alami (Sutopo 2011). Jasa ? lingkungan ialah manfaat yang diperoleh masyarakat dari hubungan timbal-balik t yang dinamis yang terjadi di dalam lingkungan hidup, antara tumbuhan, binatang, dan jasa renik dan lingkungan non-hayati. Walaupun kekayaan materi dapat membentengi perubahan lingkungan, manusia sangat tergantung pada aliran jasa lingkungan tersebut. Jasa lingkungan menjadi lebih bernilai akibat dampak = perubahan iklim. Peristiwa-peristiwa cuaca ekstrim menyebabkan perubahan ekologis lingkungan (UNESCAP 2009).

Jasa- lingkungan pohon terhadap lingkungan sekitar sangatlah besar, terutama dalam menanggulangi urban heat island yang merupakan peningkatan suhu perkotaan akibat kurangnya ruang terbuka hijau. Jasa lingkungan didefinisikan sebagai jasa yang diberikan oleh fungsi ekosistem alam maupun buatan yang nilai dan manfaatnya dapat dirasakan secara langsung maupun tidak langsung oleh para pemangku kepentingan (stakeholder) dalam rangka membantu memeliha ra dan/atau meningkatkan kualitas lingkungan secara berkelanjutan (Sriyanto 2007$)$.

\section{Pemodelan dengan CITYgreem 5.2}

Menurut buku CITYgreen 5.0 manual book, salah satu perangkat lunak buatan American Forests yaitu CITYgreen adalah sebuah aplikasi ramah lingkungăn untuk menilai jasa lingkungan suatu hutan kota. Perangkat aplikasi ini diinisiasi pada tahun 1996, dengan versi pertamanya yaitu CITYgreen 1.0 yang diluncurkân memadukan antara akademis dengan professional konservasi pohon kota. CITYgreen juga mampu menghitung keuntungan ekonomi dan jasa lingkungan yang diberikan oleh sebuah pohon dan vegetasi lainnya. Selain itu juga dapat membuat pemodelan dampak ekonomi pada berbagai pertumbuhan dan sekenario perencanaan.

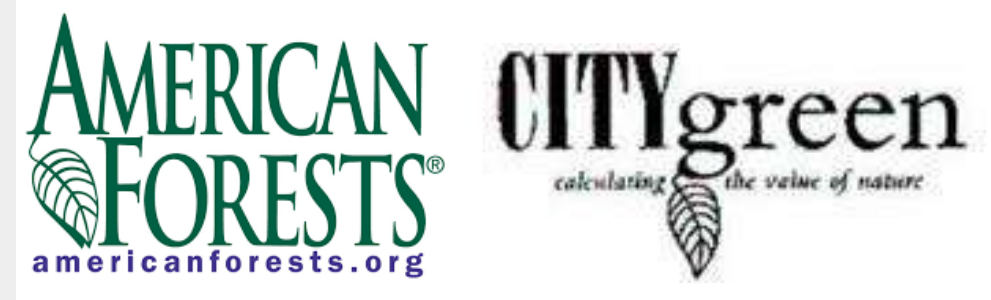

Gambar 4 Logo American Forest (Kiri) dan perangkat lunak CITYgreen (Kanan)

(Sumber: CITYgreen user manual book 2002)

CTTYgreen ini mampu menilai runoff limpasan air hujan, kualitas udara suatu kâwasan, penghematan penggunaan energi, kapasitas cadangan karbon, dan pemodelan pertumbuhan vegetasi pada suatu kawasan baik kawasan luas maupun sempit. Füngsi penilaian runoff limpasan air hujan adalah mengkalkulasi volume runoff yang dihasilkan jika vegetasi dihilangkan, jika dikalikan dengan volume biaya lokal konstruksi akan menjadi biaya yang dihemat dari suatu pembangunan. 
Fungsi penilaian kualitas udara adalah melakukan estimasi pengurangan polusi udara tiap tahunnya, untuk menghitung nilai mata uang untuk setiap polutan atau yang bisa disebut dengan nilai "penghematan eksternal" yaitu merupakan biaya tidak langsung dari kesehatan sosial dan limbah pariwisata. Fungsi estimasi cadangan karbon adalah menghitung kapasitas cadangan karbon yang dihasilkan dari siklus karbon pada vegetasi. Fungsi penghematan energi adalah penilaian penggunaan energi berdasarkan lokasi, spesies tipe vegetasi, tinggi bangunan, iklim lokal, dan biaya penggunaan AC. Dan yang terakhir adalah fungsi pemodelan pertumbuhan vegetasi secara temporal dan spasial dapat memperkirakan kondisi yang akan terjadi pada 10, 20, atau 30 tahun kedepan.

CITYgreen menggunakan basis data dengan skala yang kecil memerlukan gambar citra yang sangat detail, dan perlu adanya basis data vektor yang mendukung, sedangkan pada luasan kawasan yang luas seperti satu pulau, atau satư negara menggunakan basis data raster yang sudah terverifikasi. Didukung dengan aplikasi ArcView 3.3 yang akan mempermudah proses interpretasi data spasial yang diperoleh.

\section{Klasifikasi Jalan}

Jalan arteri sekunder adalah jalan yang menghubungkan kawasan sekunder ked端a dengan kawasan sekunder kedua atau menghubungkan kawasan sekunder kedtua dengan kawasan sekunder ketiga. Jalan arteri sekunder memiliki kriteria terdi़iri atas:

1. Jalan arteri sekunder didesain berdasarkan kecepatan rencana paling rendah $30 \mathrm{Km} / \mathrm{h}$.

2. Lebar jalan paling rendah 11 meter

3. Akses langsung dibatasi tidak boleh lebih pendek dari 250 meter,

4. Persimpangan pada jalan arteri sekunder diatur dengan pengaturan tertentu yang sesuai dengan volume lalu lintasnya.

5. Mempunyai kapasitas yang lebih besar dari volume lalu lintas rata-rata

6. Harus mempunyai perlengkapan jalan yang memadai seperti lampu jalan, rambu lalu lintas, marka jalan, lampu pengatur lalu lintas, dll.

7. Besarnya lalu lintas harian rata-rata pada umumnya paling besar dari sistem sekunder yang lain,

8. Dianjurkan tersedianya jalur khusus yang dapat digunakan untuk sepeda dan kendaraan lambat lainnya,

9. Jarak selang dengan kelas yang sejenis lebih besar dari pada jarak selang dengan kelas jalan yang lebih rendah.

Ciri-ciri jalan arteri sekunder terdiri atas:

1. Jalan arteri sekunder manghubungkan:

a. Kawasan primer dengan kawasan sekunder tertentu,

b. Antar kawasan sekunder tertentu,

c. Kawasan sekunder I dengan kawasan sekunder II, dan

d. Jalan arteri/kolektor primer dengan kawasan sekunder I.

Lalu lintas cepat pada jalan arteri sekunder tidak boleh terganggu oleh lalu lintas lambat,

Kendaraan angkut barang ringan dan bus untuk pelayanan kota dan diijinkan melalui jalan ini, 
4. Lokasi berhenti dan parkir pada badan jalan sangat dibatasi dan seharusnya tidak diizinkan pada jam sibuk.

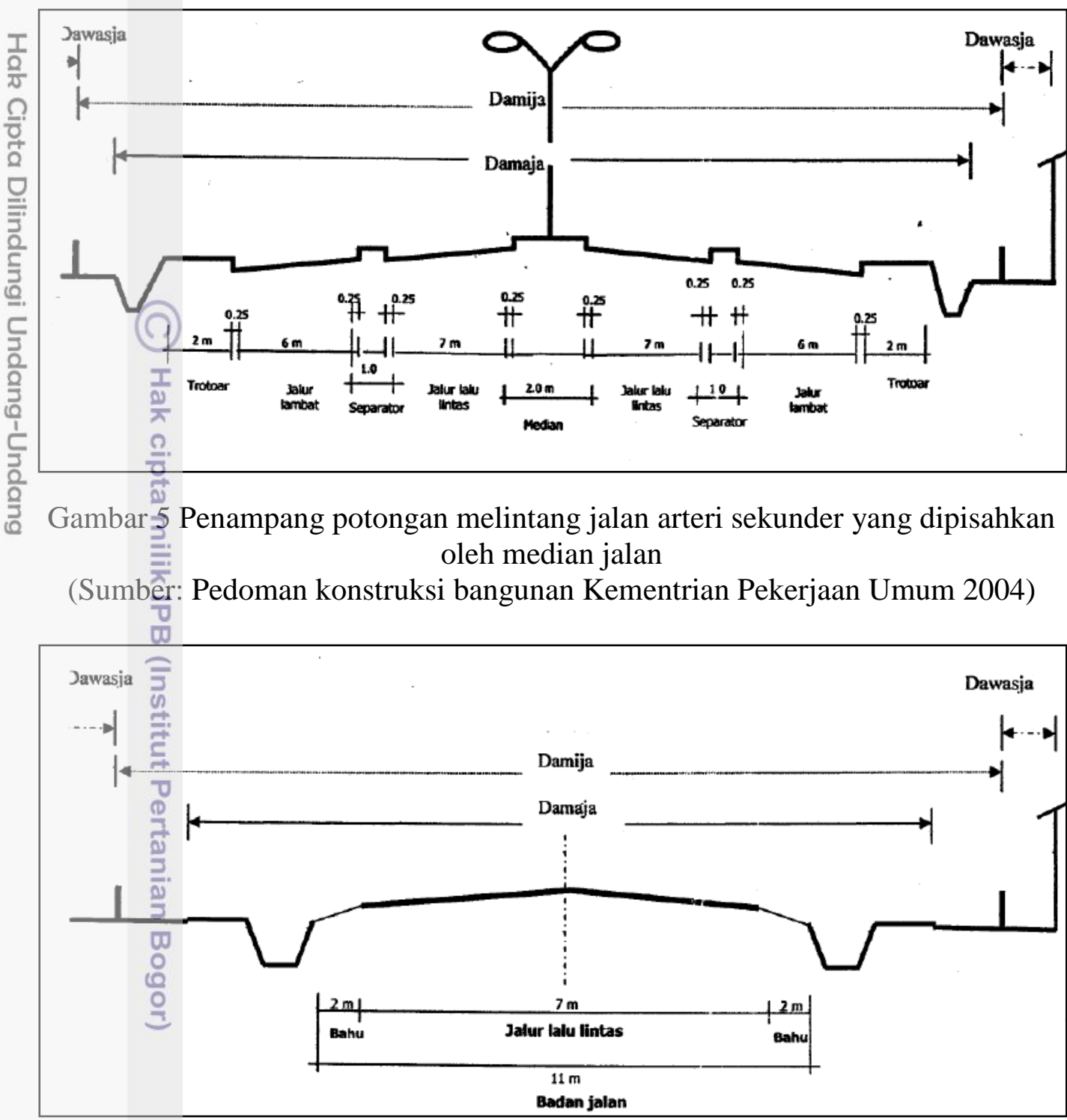

Gambar 6 Penampang potongan melintang jalan arteri sekunder tanpa median jalan

(Sumber: Pedoman konstruksi bangunan Kementrian Pekerjaan Umum 2004)

Keterangan:

1. Badan Jalan adalah bagian jalan yang meliputi seluruh jalur lalu lintas, median, dan bahu jalan.

2. Bahu Jalan adalah bagian daerah manfaat jalan yang berdampingan dengan jalur lalu lintas untuk menampung kendaraan yang berhenti, keperluan darurat, dan untuk pendukung samping bagi lapis pondasi bawah, lapis pondasi, dan lapis permukaan.

3. Batas Median Jalan adalah bagian median selain jalur tepian, yang biasanya ditinggikan dengan batu tepi jalan. 
4. Daerah di Luar Kota adalah, daerah lain selain daerah perkotaan.

5. Daerah Manfaat Jalan (Damaja) adalah daerah yang meliputi seluruh badan jalan, saluran tepi jalan dan ambang pengaman.

6. Daerah Milik Jalan (Damija) adalah daerah yang meliputi seluruh daerah manfaat jalan dan daerah yang diperuntukkan bagi pelebaran jalan dan penambahan jalur lalu lintas di kemudian hari serta kebutuhan ruangan untuk pengaman jalan.

7. Daerah Pengawasan Jalan (Dawasja) adalah lajur lahan yang berada di bawah pengawasan penguasa jalan, ditujukan untuk penjagaan terhadap terhalangnya pandangan bebas pengemudi kendaraan bermotor dan untuk pengamanan konstruksi jalan dalam hal ruang daerah milik jalan tidak mencukupi.

8. Daerah Perkotaan adalah daerah kota yang sudah terbangun penuh atau areal pinggiran kota yang masih jarang pembangunannya yang diperkirakan akan menjadi daerah yang terbangun penuh dalam jangka waktu kira-kira 10 tahun mendatang dengan proyek perumahan, industri, komersil, dan berupa pemanfaatan lahan lainnya yang bukan untuk pertanian.

\section{Strüktur Kawasan perkotaan dan sistem jaringan jalan sekunder}

Struktur kawasan perkotaan dapat dibagi dalam beberapa kawasan berdasarkan fungsi dan hirarkinya antara lain, kawasan primer, sekunder dan perumahan. Hubungan antara kawasan perkotaan dengan peranan ruas jalan dalam sistem jaringan jalan sekunder diberikan pada Tabel 1 .

Tabel 1 Hubungan antara kawasan perkotaan dengan peranan ruas jalan dalam sistem jaringan jalan sekunder

\begin{tabular}{|c|c|c|c|c|c|}
\hline \multirow{2}{*}{$\begin{array}{c}\text { KAWASAN } \\
0 \\
0 \\
0 \\
0\end{array}$} & PRIMER & SEKUNDER I & $\begin{array}{l}\text { SEKUNDER } \\
\text { II }\end{array}$ & $\begin{array}{c}\text { SEKUNDER } \\
\text { III }\end{array}$ & \multirow[t]{2}{*}{ PERUMAHAN } \\
\hline & (F1) & $(\mathrm{F} 2,1)$ & $(\mathrm{F} 2,2)$ & $(\mathrm{F} 2,3)$ & \\
\hline PRIMER (F1) & - & Arteri & - & - & - \\
\hline $\begin{array}{l}\text { SEKUNDER I } \\
(\mathrm{F} 2,1)\end{array}$ & Arteri & Arteri & Arteri & - & Lokal \\
\hline $\begin{array}{l}\text { SEKUNDER II } \\
(\mathrm{F} 2,2)\end{array}$ & - & Arteri & Kolektor & Kolektor & Lokal \\
\hline $\begin{array}{l}\text { SEKUNDER III } \\
(\mathrm{F} 2,3)\end{array}$ & - & - & Kolektor & Kolektor & Lokal \\
\hline PERUMAHAN & - & Lokal & Lokal & Lokal & Lokal \\
\hline
\end{tabular}

\section{Ruang Terbuka Hijau (RTH)}

Menurut Permen PU No 12 Tahun 2009 Tentang Pedoman Penyediaan dan Pemanfaatan Ruang Terbuka Non Hijau di Kawasan Perkotaan, Ruang Terbuka Hijau (RTH) adalah area memanjang/jalur dan atau mengelompok, yang penggunaannya lebih bersifat terbuka, tempat tumbuh tanaman, baik yang tumbuh tanaman secara alamiah maupun yang sengaja ditanam. Ruang Terbuka Non Hijau (RTNH) adalah ruang terbuka di bagian wilayah perkotaan yang tidak termasuk dalam kategori RTH, berupa lahan yang diperkeras atau yang berupa badan air, 
maupun kondisi permukaan tertentu yang tidak dapat ditumbuhi tanaman atau berpori.

Berdasarkan kepemilikannya RTH dibagi menjadi ruang terbuka hijau To privat adalah RTH milik institusi tertentu atau orang perseorangan yang $\approx$ pemanfaatannya untuk kalangan terbatas antara lain berupa kebun atau halaman orumah/gedung milik masyarakat/swasta yang ditanami tumbuhan, dan ruang 5 terbuka hijau publik adalah RTH yang dimiliki dan dikelola oleh pemerintah daerah kota/kabupaten yang digunakan untuk kepentingan masyarakat secara umum, antara lain berupa taman kota; taman pemakaman umum; dan jalur hijau sepanjang jalan, sungai, serta pantai.

RTNH merupakan ruang terbuka di wilayah kota/kawasan perkotaan yang tidak termasuk dalam kategori RTH, yaitu berupa lahan yang diperkeras maupun yang berupa badan air. Pedoman ini memberikan rujukan sepanjang yang berkaitan dengan ruang terbuka perkerasan. Ketentuan mengenai ruang terbuka biru dan Rondisi tertentu lainnya diatur dalam pedoman tersendiri.

Sallah satu bagian dari RTH adalah Jalur hijau jalan. Jalur hijau jalan adalah jatur penempatan tanaman serta elemen lansekap lainnya yang terletak di sepanjang sistem jaringan prasarana, antara lain: sepanjang jalan, yang meliputi ruang mílik jalan (Rumija) dan ruang pengawasan jalan (Ruwasja), serta sepanjangs sungai, yang berupa sempadan sungai. 


\section{METODE}

\section{Lokasi Penelitian}

Lokasi penelitian dilakukan di Kota Bogor, Provinsi Jawa Barat, Indonesia, yaitu Jalan arteri sekunder yang terdapat di Kota Bogor, yaitu JL. Ir. H. Juanda, JL. Jendral Sudirman, JL. Pemuda, JL. Raya Pajajaran, JL. Jalak Harupat, JL. R.E Martadinata, JL. Ahmad Yani, JL. Otto Iskandardinata, JL. Raya Empang, dan JL. Dadali. Gambar peta jalan di Kota Bogor disajikan dalam Gambar 7.

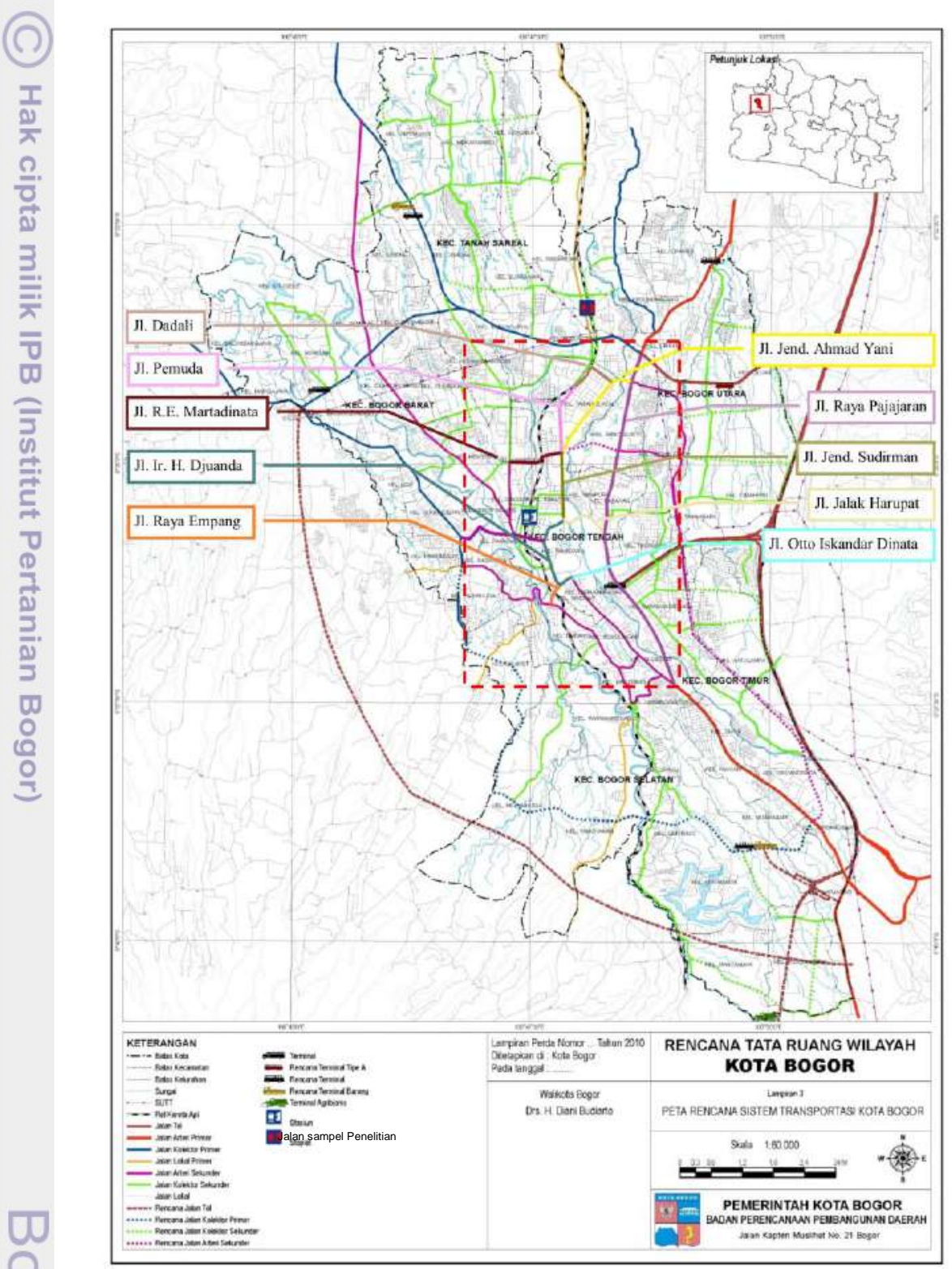

Gambar 7 Lokasi penelitian di Kota Bogor, Provinsi Jawa Barat, Indonesia (Sumber: BAPPEDA Kota Bogor 2016) 
Pemilihan 10 lokasi penelitian berdasarkan kriteria yang bersumber dari data-data dinas terkait yang penentuannya menggunakan kriteria pada Tabel 2 berikut ini.

동 Tabel 2 Kriteria penentuan lokasi penelitian

\section{No. Kriteria Lokasi}

1. Berdasarkan klasifikasi jalan paling rendah merupakan jalan arteri sekunder ㅁ. di Kota Bogor ${ }^{1}$

2. Merupakan jalan dengan volume kendaraan yang melintas diatas 1.000 kendaraan/jam ${ }^{2}$

3. Merupakan jalan yang memiliki data emisi gas buang kendaraan bermotor ${ }^{3}$

4. Jalan yang memiliki jalur hijau jalan yang ditanami oleh pohon besar

Sumber: Kementrian PU 2004 ${ }^{1}$, BAPPEDA $2011^{2}$, BPLH $2015^{3}$

\section{Waktu Penelitian}

Waktu penelitian dilakukan pada bulan Agustus 2015 hingga September 2016, detail jadwal penelitian disajikan pada Tabel 3.

Tabel 3 Tabel jadwal kegiatan penelitian

\begin{tabular}{|c|c|c|c|c|c|c|c|c|c|c|c|c|c|c|c|}
\hline \multirow[b]{2}{*}{ NO } & \multirow{2}{*}{ KEGIATAN } & \multicolumn{5}{|c|}{ TAHUN 2015} & \multicolumn{9}{|c|}{ TAHUN 2016} \\
\hline & & $\mathrm{Ags}$ & Sep & Okt & Nov & Des & Jan & Feb & Mar & Apr & Mei & Jun & Jul & Ags & Sep \\
\hline 1 & $\begin{array}{l}\text { Tahap } \\
\text { persiapan } \\
\text { proposal dan } \\
\text { perizinan }\end{array}$ & & & & & & & & & & & & & & \\
\hline 2 & $\begin{array}{l}\text { Tahâp } \\
\text { pengambilan } \\
\text { datagdan } \\
\text { inventarisasi }\end{array}$ & & & & & & & & & & & & & & \\
\hline 3 & Input data & & & & & & & & & & & & & & \\
\hline 4 & Analisis data & & & & & & & & & & & & & & \\
\hline 5 & $\begin{array}{l}\text { Rekomendasi } \\
\text { dan } \\
\text { kesimpulan }\end{array}$ & & & & & & & & & & & & & & \\
\hline
\end{tabular}


Alat

Peralatan yang digunakan dalam penelitian ini adalah alat-alat keperluan survei langsung pada tapak, untuk lebih jelasnya disajikan secara lebih terperinci pada Tabel 4.

Tabel 4 Tabel Keperluan peralatan yang digunakan dalam penelitian

\begin{tabular}{|c|c|c|c|}
\hline No & Kegiatan & Alat yang digunakan & Kegunaan \\
\hline & Inventarisasi & GPS & Digitasi pohon sample \\
\hline 2. & Dokumentasi & Kamera & Dokumentasi objek \\
\hline & $\begin{array}{l}\text { Pengukuran } \\
\text { diameter batang } \\
\text { pohon }\end{array}$ & Meteran gulung & $\begin{array}{l}\text { Mengetahui diameter batang } \\
\text { pohon }\end{array}$ \\
\hline & $\begin{array}{l}\text { Pengukuran } \\
\text { diameter tajuk } \\
\text { setinggi dada }\end{array}$ & Meteran gulung & $\begin{array}{l}\text { Mengetahui diameter tajuk } \\
\text { pohon }\end{array}$ \\
\hline & $\begin{array}{l}\text { Pengukuran tinggi } \\
\text { pohon }\end{array}$ & Klinometer & Mengetahui tinggi pohon \\
\hline 6. & Input data & Software : & Mengolah data hasil \\
\hline & & 2. Microsoft Word 2010 & inventarisasi \\
\hline & & 3. Microsoft Acess 2010 & \\
\hline & & 4. Garmin MapSource & \\
\hline & & 5. GIS 9.3 & \\
\hline 7. & $\begin{array}{l}\text { Penilaian Jasa } \\
\text { Lingkungan }\end{array}$ & $\begin{array}{l}\text { ArcView } 3.2 \text { ekstensi } \\
\text { CITYgreen } 5.2\end{array}$ & analisis jasa lingkungan \\
\hline
\end{tabular}

Bahan yang dibutuhkan dalam penelitian ini merupakan keperluan data yang diperoleh dari survei langsung ke tapak maupun juga yang diperoleh dari instânsi terkait, untuk lebih jelasnya disajikan secara terperinci pada Tabel 5.

Tabel 5 Bahan yang diperlukan dalam penelitian

\begin{tabular}{|c|c|c|c|}
\hline Aspek & Jenis Data & $\begin{array}{l}\text { Sumber } \\
\text { Data }\end{array}$ & $\begin{array}{c}\text { Cara Memperoleh } \\
\text { Data }\end{array}$ \\
\hline Lokasi Pohon & Titik lokasi pohon & Lapang & Survei lapang \\
\hline \multirow{5}{*}{$\begin{array}{l}\text { Kondisi fisik } \\
\text { pohon }\end{array}$} & Spesies pohon & \multirow{6}{*}{ Lapang } & \multirow{6}{*}{ Survei lapang } \\
\hline & Tinggi pohon & & \\
\hline & Diameter Kanopi & & \\
\hline & Diameter batang setinggi dada & & \\
\hline & Foto pohon & & \\
\hline$\infty$ & Kondisi kesehatan & & \\
\hline Kondisi polusi & Ambien konsentrasi polusi & BPLH & Studi pustaka \\
\hline \multirow{4}{*}{ Péa dasar } & Peta Citra & \multirow{4}{*}{ BAPEDA } & \multirow{4}{*}{ Studi pustaka } \\
\hline & Peta Administratif & & \\
\hline & Peta Jaringan jalan & & \\
\hline & Peta Sistem transportasi & & \\
\hline
\end{tabular}


Lanjutan Tabel 5 Bahan yang diperlukan dalam penelitian

\begin{tabular}{|c|c|c|c|}
\hline \multirow{3}{*}{$\begin{array}{l}\text { Kendaraan } \\
\text { bermotor }\end{array}$} & Volume kendaraan bermotor & \multirow{3}{*}{ DLLAJ } & \multirow{3}{*}{ Studi Pustaka } \\
\hline & $\begin{array}{l}\text { Proporsi penggunaan } \\
\text { kendaraan bermotor }\end{array}$ & & \\
\hline & Konsumsi bahan bakar & & \\
\hline Klimatologi & $\begin{array}{l}\text { Curah hujan rata-rata dan iklim } \\
\text { kota Bogor }\end{array}$ & BMKG & Studi Pustaka \\
\hline \multicolumn{4}{|c|}{ Batasan Studi } \\
\hline \multicolumn{4}{|c|}{$\begin{array}{l}\text { Batasan dalam penelitian ini adalah mengkaji kualitas kanopi pohon dalam } \\
\text { erikan jasa lingkungan dalam menyerap polusi udara di Kota Bogor, } \\
\text { erkifakan kapasitas penyimpanan karbon di Kota Bogor, dan membuat } \\
\text { endâsi tata hijau yang dapat dijadikan sebagai masukan bagi pemerintah } \\
\text { oger. }\end{array}$} \\
\hline
\end{tabular}

\section{Metode Penilaian Jasa Lingkungan}

Tahapan yang dilakukan dalam penelitian dengan metode penilaian jasa lingkungan terbagi menjadi 6 tahapan secara umum yaitu tahap perizinan, tahap inventarisasi, tahap input data, tahap analisis, dan tahapan menuju rekomendasi.

\section{Tahap pẹrizinan}

Merupakan tahapan pembuatan surat izin yang terkait dengan keperluan pengambifan data seperti pada Pemerintah Kota Bogor yaitu Dinas Kebersihan dan Pertamanan (DKP) Kota Bogor, Badan Perencanaan dan Pembangunan Daerah (BAPEDA) Kota Bogor, Dinas Lalu Lintas dan Angkutan Jalan (DLLAJ) Kota Bogor, dan Badan Pengelolaan Lingkungan Hidup (BPLH) di Kota Bogor.

\section{Tahapang Inventarisasi}

Proses inventarisasi bertujuan untuk mendapatkan data yang langsung diamati dilapang yaitu titik lokasi pohon, kondisi fisik pohon, dan dokumentasi pohon. Secara umum tahapan inventarisi terbagi menjadi 2 yaitu identifikasi lokasi pohon, dan identifikasi kondisi fisik pohon. Proses yang harus dilalui adalah sebagai berikut:

1. Tahapan identifikasi lokasi pohon

Penelitian ini mengambil sampel pada 10 ruas jalan arteri sekunder di Kota Bogor dimana pada setiap tapak diidentifikasi pohon pada jalur hijau jalan. Pohon yang masuk kualifikasi adalah pohon yang sudah berusia tua (diameter batang $>30 \mathrm{~cm}$ ), dan memiliki tutupan kanopi yang lebar, berikut ini merupakan kriteria pohon yang diteliti untuk dilakukan proses sensus pohon yang ditunjukan pada Tabel 6 berikut ini.

Tabel 6 Kriteria pohon yang diteliti pada penelitian ini

\begin{tabular}{ll}
\hline No & \multicolumn{1}{c}{ Kriteria } \\
\hline 1. & Pohon yang berada pada jalur hijau jalan lokasi penelitian \\
\hline 2. & Merupakan pohon yang memiliki diameter kanopi $>3 \mathrm{~m}$ \\
\hline 3. & Meupakan pohon yang memiliki diameter batang $>30 \mathrm{~cm}$ \\
\hline 4. & Merupakan pohon yang sudah berusia dewasa $(>30$ tahun $)$ \\
\hline
\end{tabular}


Tahapan identifikasi lokasi pohon merupakan tahapan yang diperoleh dengan cara observasi langsung ke lokasi tapak. Tahapan ini terdiri dari titik lokasi pohon ( $x$ latitude dan y longitude) yang diamati dengan menggunakan GPS (Global Positioning System) dengan cara membuat waypoint pada setiap pohon yang terdapat di jalur hijau jalan yang diamati satu-persatu.

Setiap pohon yang diamati diberikan kode-kode unik untuk memudahkan dalam penyusunan data. Kode pohon disusun dari nama jalan, dan urutan pohon, dan kode nama lokal pohon. Salah satu contoh kode pohonnya yaitu "AHM0001KNR". Kode "AHM" meupakan kode untuk nama Jalan Jendral Ahmad Yani, sedangkan kode "0001" adalah nomor urut pohon, dan "KNR" adalah nama kode lokal pohon yaitu kenari. Jadi kode pohon "AHM0001KNR" berarti pohon kenari yang pertama di Jalan Jendral Ahmad Yani. Untuk lebih leng̈kapnya, daftar kode nama jalan dan nama lokal pohon disajikan pada Lampiran 11 dan Lampiran 12.

2. Tahapan identifikasi kondisi fisik pohon

Tahapan identifikasi kondisi fisik pohon yang dilakukan mengikuti beberapa prosedur yang terdiri dari berikut ini:

a) Mengukur tinggi pohon dengan alat klinometer

Tinggi pohon diukur menggunakan klinometer. Data dari klinometer berupa sudut pengamat. Melalui data tersebut, dapat dicari tinggi pohon menggunakan rumus trigonometri. Rumus untuk mencari tinggi pohon adalah:

Keterangan:

$$
h=y+(S \times \tan \alpha)
$$

$\alpha \quad$ : Sudut yang didapat menggunakan klinometer.

h : Tinggi pohon $(\mathrm{m})$.

y : Tinggi pengamat $(\mathrm{m})$.

s : Jarak pengamat dari titik pohon $(\mathrm{m})$

b) Mengukur diameter batang pohon

Pengukuran diameter batang pohon setinggi dada/DBH (diameter from breast height) dengan meteran gulung menggunakan rumus:

Keterangan:

$$
\text { DB H }=\frac{K}{\pi}
$$

DBH : Diameter batang setinggi dada

$\mathrm{K} \quad$ : Keliling atau lingkar batang pohon

$\pi \quad: 3.14$

Teknik pengukuran dilakukan pada seluruh tipe percabangan pohon. Gambar 8 dan 9 merupakan teknik memperoleh diameter pada tipe percabangan dan kondisi batang pohon yang berbeda-beda. 

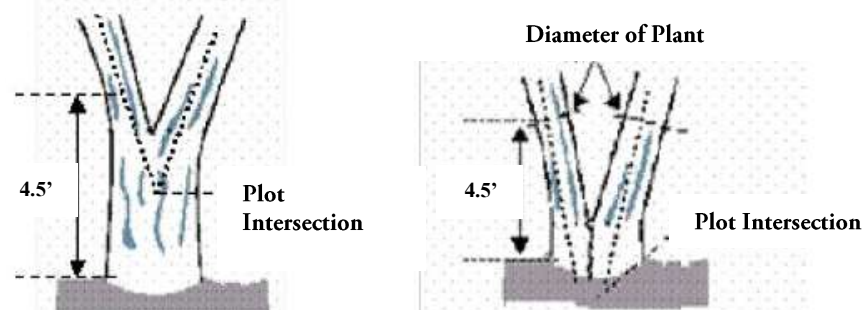

Gambar 8 Teknik pengambilan data diameter pohon setinggi dada pada pohon dengan batang utama bercabang (Sumber: USDA $i$-Tree user manual books)
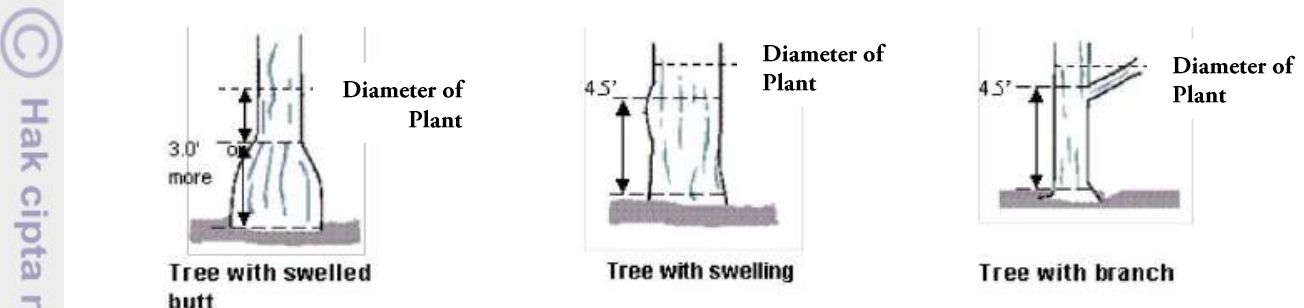

Diameter of

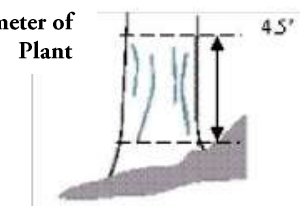

Tree on a slope

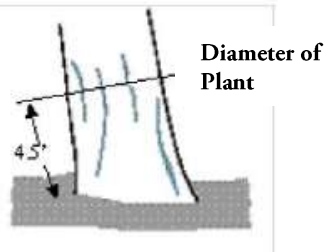

Leaning tree

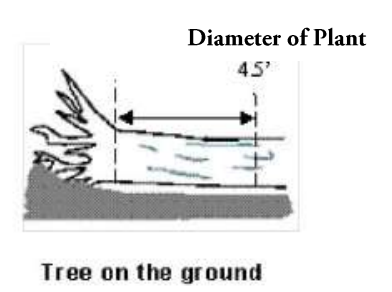

Gambar 9 Teknik pengambilan data diameter pohon setinggi dada pada pohon dengan batang utama beragam bentuk

(Sumber: USDA $i$-Tree user manual books)

๔) Mengukur diameter kanopi dengan meteran gulung

․ Pengukuran diameter kanopi dilakukan dengan cara mengukur $\mathrm{r}$ (Jari-jari) kanopi terlebih dahulu, kemudian dengan rumus sebagai berikut:

$$
D=r \times 2
$$

Keterangan:

$\mathrm{D}=$ Diameter kanopi

$r=$ Jari-jari kanopi

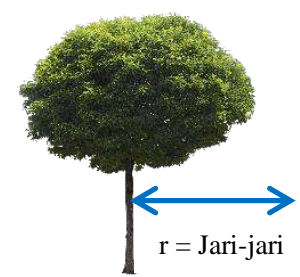

Gambar 10 Pengukuran diameter kanopi

(Sumber: Skechuptexture.com) 
d) Memperoleh dokumentasi foto pohon

Pengambilan gambar atau dokumentasi foto dilakukan dengan tujuan memperoleh gambaran seluruh tubuh pohon. Pengambilan foto dilakukan dari jarak yang jauh agar seluruh tubuh pohon terlihat dengan jelas. Seperti pada Gambar 11 berikut ini

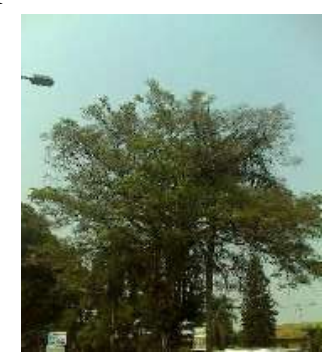

Gambar 11 Foto pohon yang menggambarkan seluruh bagian pohon dari atas hingga ke bawah

Tahapan Input Data

Tahapan awal input data adalah digitasi yaitu pemisahan antara kanopi dan non $\overline{\text { k }}$ kanopi hal ini untuk mempermudah pada proses analisis. Kemudian pengelompokan site dan penentuan sampel berdasarkan presentase penutupan lahส̆ oleh kanopi. Hal ini dilakukan karena pada lokasi penelitian terdapat luasan penutupan lahan oleh kanopi pohon yang berbeda-beda. Selain itu hal ini dilakukan untuk mempermudah proses analisis kapasitas penyerapan karbon. Setelah itu melakukan pengumpulan data atribut canopy theme yaitu data mengenai pohon yang terdapat pada lokasi penelitian yang diamati.

Data-data fisik pohon yang diamati dimasukan pada tahap pembuatan atribut canopy theme, data yang perlu dimasukan adalah spesies pohon, tinggi pohön, nilai kondisi pohon, DBH (Diameter of breast height) pohon, kondisi kesehatan, dan kondisi pertumbuhan pohon. Adapun kriteria kelas kesehatan pohon, kelas pertumbuhan pohon, dan tinggi pohon disajikan dalam Tabel 7 berikut ini.

Tabel 7 Kriteria kelas kesehatan pohon, kelas pertumbuhan pohon, dan tinggi pohon.

\begin{tabular}{lll}
\hline Nilai kesehatan pohon & Nilai pertumbuhan pohon & Kelas tinggi pohon \\
\hline 1= Sangat buruk & 1= Buruk & $1=<20$ feet \\
2= Buruk & 2= Sedang & $2=20-24$ feet \\
$3=$ Sedang & 3= Baik & $3=>45$ feet
\end{tabular}

$4=$ Baik

5=Sangat baik

Sumber: User manual book CITYgreen 5.0

\section{Tahapan Pengolahan Data}

Tahapan pengolahan data yang sudah diperoleh dari proses inventarisasi kemudian diolah dengan menggunakan teknik pemodelan analisis kuantitatif yang 
dilakukan oleh perangkat lunak ArcView 3.2 Ekstensi CITYgreen 5.2, dan teknik. Berikut adalah prosedur kerja yang harus dilakukan.

1. Tahapan pengolahan data dengan perangkat lunak ArcView 3.2 ekstensi CITYgreen 5.2

Tahapan ini adalah tahapan untuk memperoleh data nilai oleh pohon pada setiap jalan. Prosedur kerja yang dilakukan adalah sebagai berikut:

1. Membuka jendela ArcView 3.3 dengan cara klik New, kemudian akan muncul jendela View, seperti ditunjukan pada Gambar 12 berikut ini.

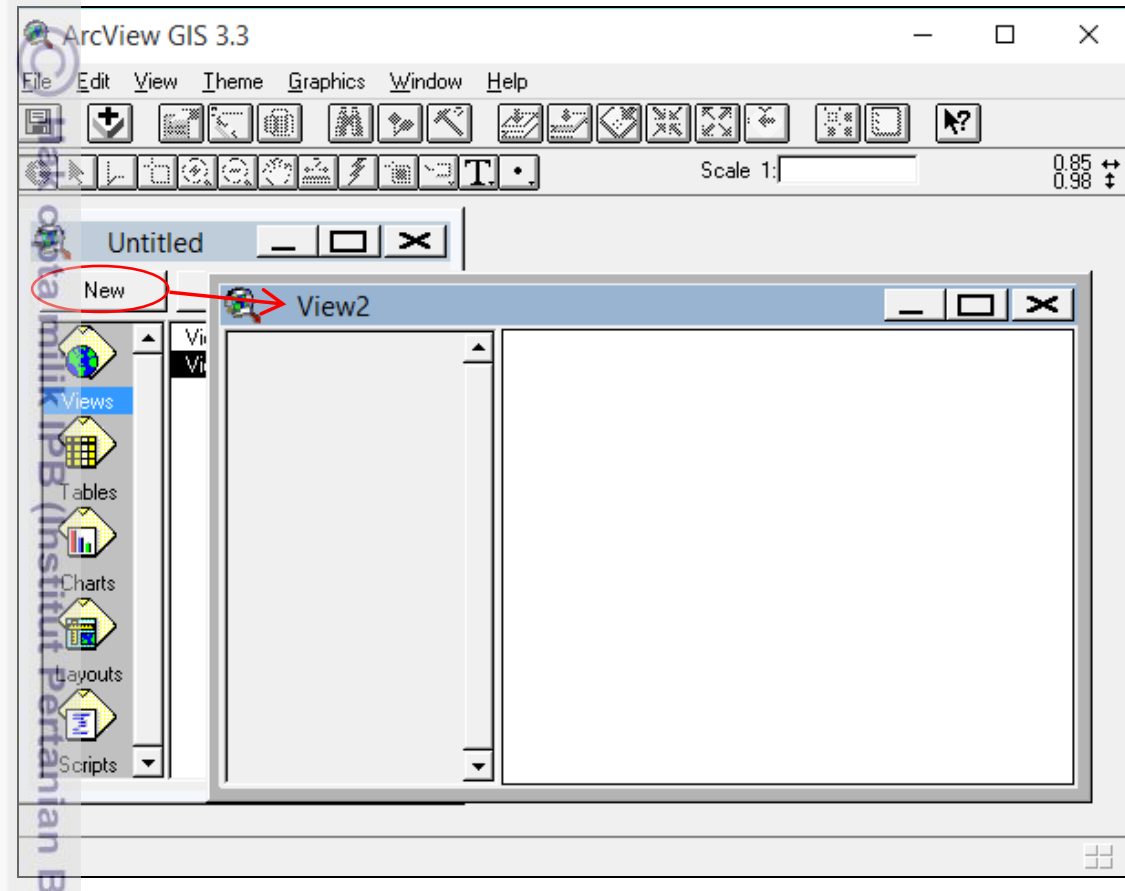

Gambar 12 Jendela ArcView 3.3 untuk membuka jendela View baru $2 \stackrel{ }{?}$

Untuk memunculkan toolbar CITYgreen 5.2 dilakukan dengan cara mengklik File $\rightarrow$ Extention akan muncul jendela Extention kemudian pilih $\sqrt{ }$ (Cheklist) CITYgreen.V5, IMAGNE Image support, JPEG (JIFF) Image support, dan Spatial Analyst pada menu Available Extention seperti pada Gambar 13 berikut ini. Kemudian klik OK untuk mengakhiri.

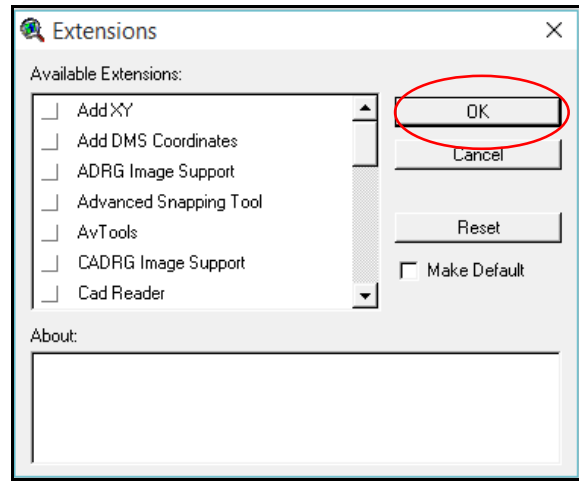

Gambar 13 Jendela Extention pada ArcView 3.3 
3. Prosedur selanjutnya adalah membuka data View theme yang telah dibuat pada tahapan input data. Data theme dibedakan menjadi empat tipe layer yaitu terdiri dari sebagai berikut:

a. Theme 1 yaitu gambar rangkaian jalan dengan ekstensi file .img,

b. Theme 2 adalah batas tapak dengan ekstensi .shp,

c. Theme 3 adalah batas jalan dengan ekstensi .shp, dan

d. Theme 4 adalah vegetasi dengan ekstensi .shp.

Cara membuka theme adalah dengan mengklik toolbar add theme $₫$, kemudian pilih (•) pada pilihan Directories lokasi file disimpan, pilih data source type adalah image data source untuk membuka Theme 1.img lalu klik $\boldsymbol{O} \boldsymbol{K}$ seperti pada Gambar 14 berikut ini.

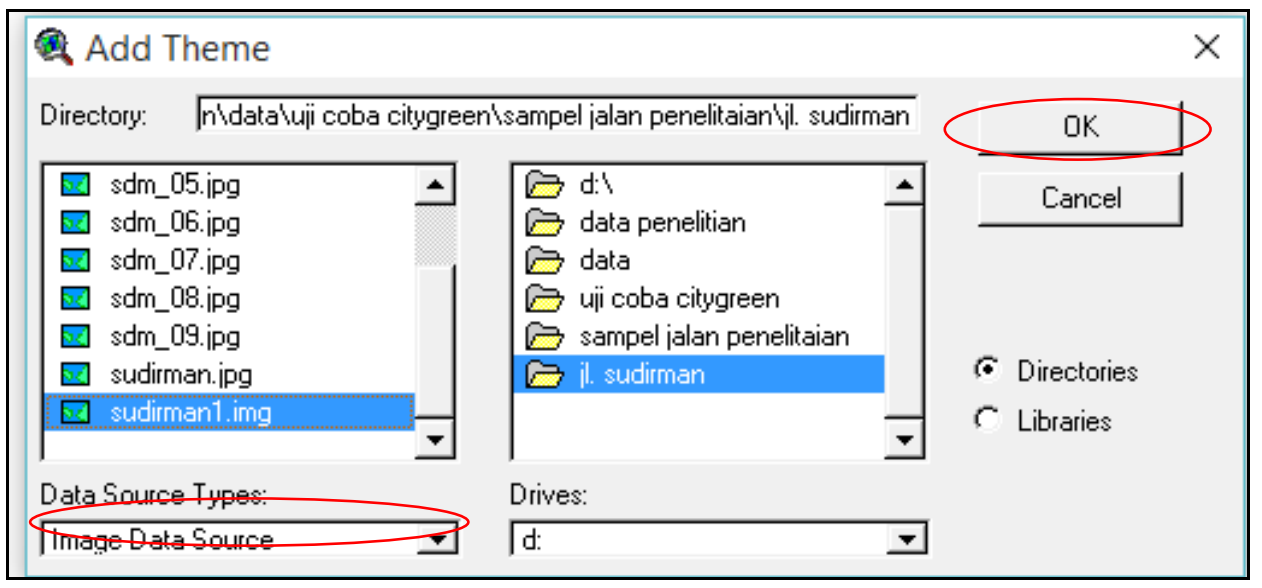

Gambar 14 Jendela Add Theme untuk membuka file dengan tipe ekstensi .img

Prosedur selanjutnya adalah membuka Theme dengan tipe ekstensi .shp.

Cara membukanya adalah dengan mengklik toolbar add theme $\downarrow$, kemudian pilih (•) pada pilihan Directories lokasi file disimpan, pilih data source type adalah Feature data source untuk membuka Theme 2.shp lalu klik $\boldsymbol{O K}$ seperti pada Gambar 14 berikut ini. Prosedur ini berlaku seluruh untuk Theme dengan ekstensi .shp.

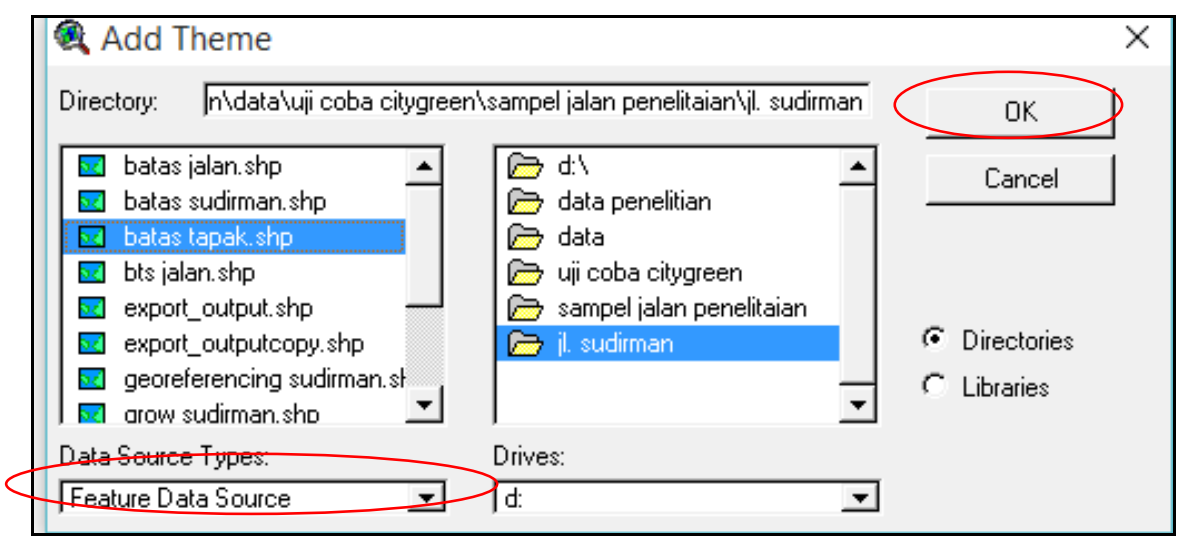

Gambar 15 Jendela Add Theme untuk membuka file dengan tipe ekstensi .$s h p$ 
4. Proses selanjutnya adalah melakukan updating atribut data frame pada CITYgreen dengan cara mengaktifkan Theme yang akan di-update yaitu dengan mengklik Theme yang akan diaktifkan kemudian klik Menubar Theme, kemudian memilih Start Editing, proses selengkapnya terlihat pada Gambar 16 berikut ini.

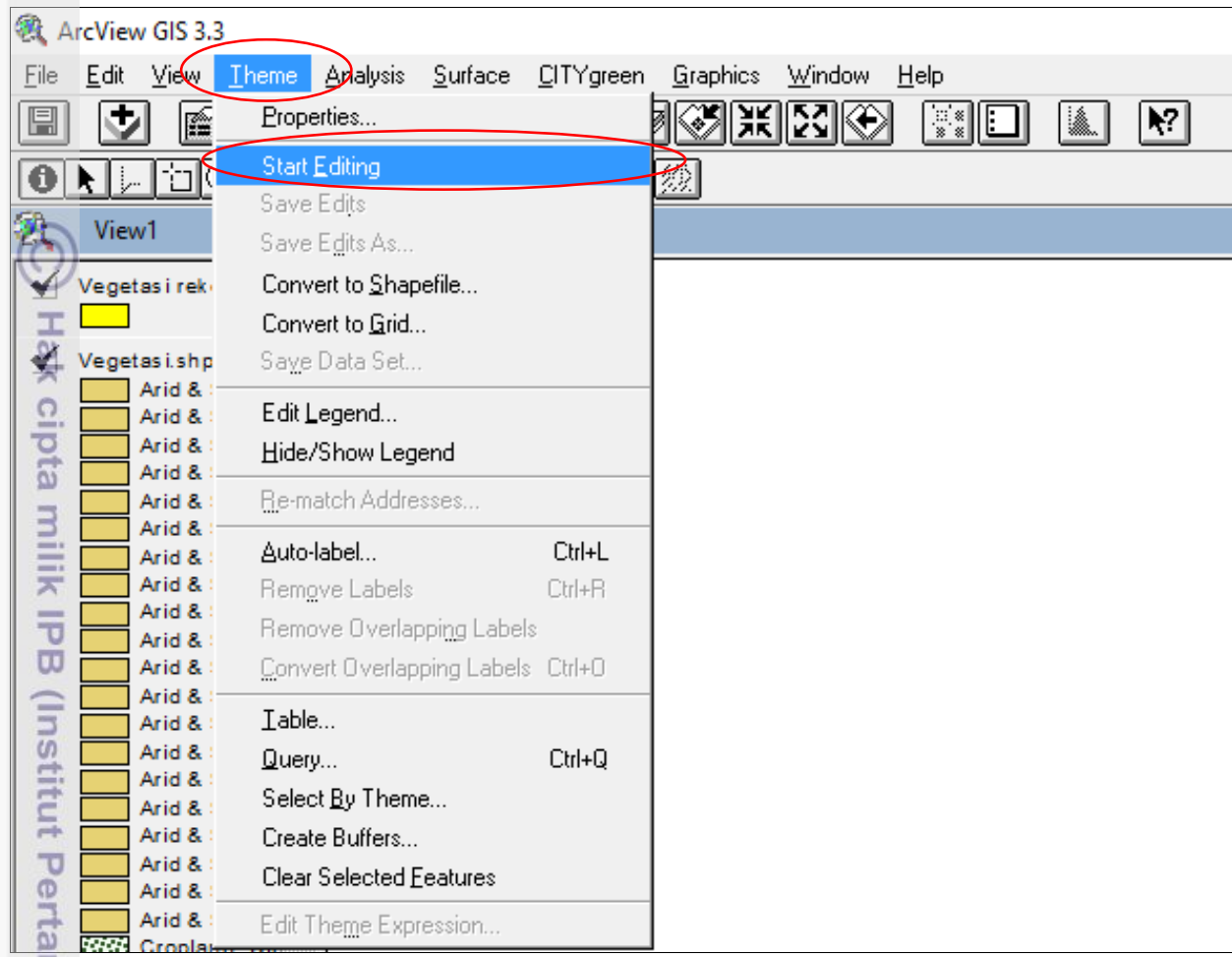

Gambar 16 Proses mangaktifkan theme pada CITYgreen

Seftelah melakukan aktifasi theme maka proses selanjutnya adalah yang mengupdate data pada theme yang sudah aktif terdiri dari sebagai berikut:

$\cong$ a. Theme 1 Batas tapak: Add/Update Data dilakukan setelah theme

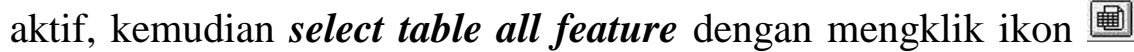
untuk ditambahkan data CITYgreen feature, lalu pilih CITYgreen pada Menu Bar, setelah jendela tabel terbuka kemudian select

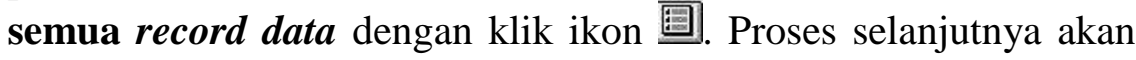
muncul jendela landcover.dbf seperti pada Gambar 17 berikut ini, terdapat beberapa pilihan tutupan lahan pada batas lokasi dipilih adalah Urban, kemudian pilih commercial/business, dan untuk mengakhiri klik Apply. 


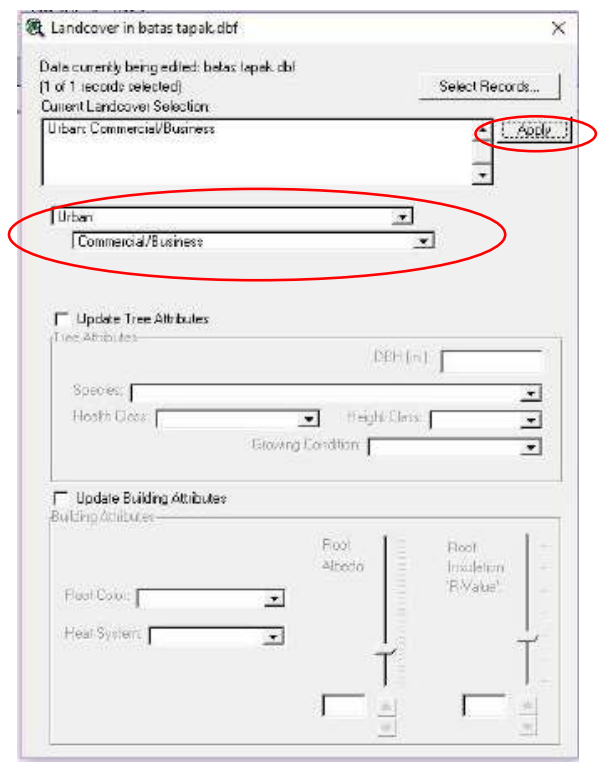

Gambar 17 Add/update data untuk landcover urban

b. Theme 2 Perkerasan Jalan: Add/Update Data dilakukan setelah theme aktif, kemudian select table all feature dengan mengklik ikon 渔 untuk ditambahkan data CITYgreen feature, lalu pilih CITYgreen pada Menu Bar, setelah jendela tabel terbuka kemudian select semua record data dengan klik ikon 国. Proses selanjutnya akan muncul jendela landcover.dbf seperti pada Gambar 18 berikut ini, terdapat beberapa pilihan tutupan lahan pada perkerasan jalan dipilih adalah Impervious survaces, kemudian pilih Paved, pilih Drain to open ditches pada jalan dengan saluran drainase yang terbuka, dan untuk mengakhiri klik Apply.

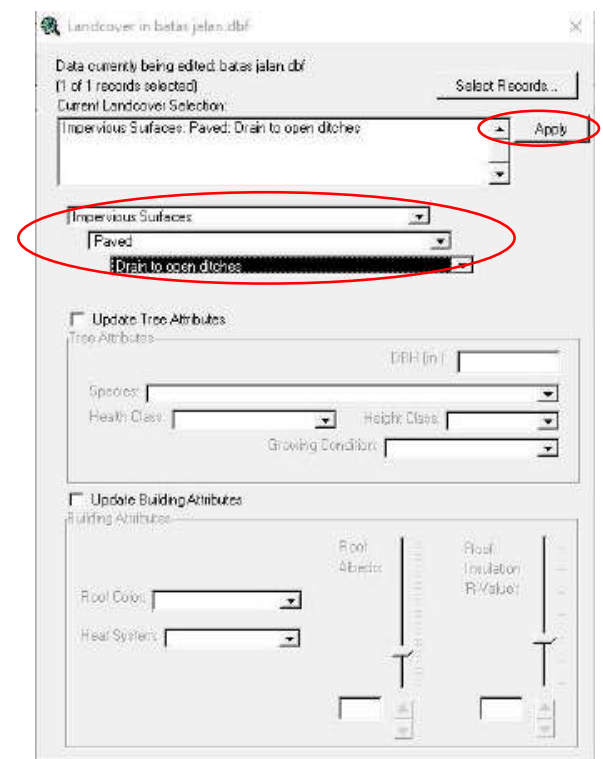

Gambar 18 Add/update data untuk landcover imperviouse

c. Theme 3 Vegetasi: Add/Update Data dilakukan setelah theme aktif, kemudian select table all feature dengan mengklik ikon 團 
untuk ditambahkan data CITYgreen feature, lalu pilih CITYgreen pada Menu Bar, setelah jendela tabel terbuka kemudian select semua record data dengan klik ikon 国. Proses selanjutnya akan muncul jendela landcover.dbf seperti pada Gambar 19 berikut ini, terdapat beberapa pilihan tutupan lahan pada Vegetasi dipilih adalah Trees, kemudian pilih Forest liter understory, pilih No grazing, forest liter and bush adequately cover soil, dan pilih (Checklist) pada menu Update Tree Atributes bertujuan untuk dilakukan proses input data fisik pohon yang akan dijelaskan pada proses selanjutnya, dan untuk mengakhiri klik Apply.

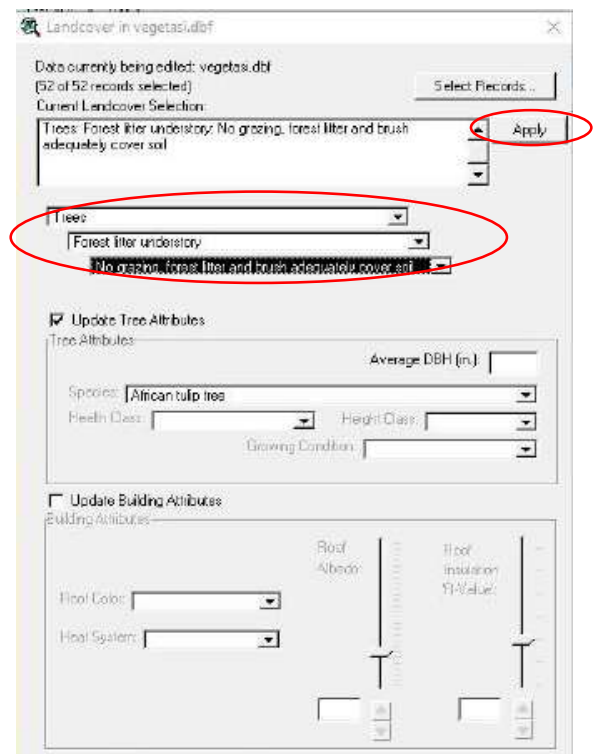

Gambar 19 Add/update data untuk landcover trees

5. Proses selanjutnya adalah input data fisik pohon (Data Attributes). Data yaing harus diisikan pada proses ini adalah DBH (Diameter of breast height) dalam satuan inchi, nama spesies pohon, nilai kesehatan pohon, kelas ketinggian pohon, dan kondisi pertumbuhan pohon yang kriterianya telah dijelaskan pada tabel 7. Data yang diinputkan tersaji pada Gambar 20 berikut ini.

\begin{tabular}{|c|c|c|c|c|c|c|c|c|c|}
\hline \multicolumn{8}{|c|}{ Attributes of Vegetasi.shp } & $\square$ & \multirow[t]{2}{*}{$x$} \\
\hline Shape & Id & Cgfeature & Cg_id & Diameter & Common & Health & Ht_clss & Grow_cond & \\
\hline Poluqon & 1 & Trees: Forest litter understory. \& & 1 & 15 & Canarium communae & 5 & 2 & 3 & $\Delta$ \\
\hline Polygon & 2 & Trees: Forest litter understory: f: & 2 & 23 & Canarium communae & $5:$ & 2 & 3 & \\
\hline Polygon & 3 & Trees: Forest litter understory: If & 3 & 37 & Canarium communae & $5:$ & 3. & 3. & \\
\hline Polygon & 4 & Trees: Forest litter understory: I & 4 & 33 & Canarium communae & 5 & 3 & 3 & \\
\hline Polygon & 5 & Trees: Forest litter understory: If & 5 & 28 & Canarium communae & 5 & 3 & 3 & - \\
\hline Polygon & 6 & Trees: Forest litter understory: I & 6 & 25 & Canarium communae & 5 & 3 & 3 & \\
\hline Polygon & 7 & Trees: Forest litter understory. I & 7 & 18 & Canarium communae & $5:$ & 3 & 3. & \\
\hline Polugon & 8 & Trees: Forest litter understory: I & 8 & 37 & Canarium communae & 5 & 3 & 3 & \\
\hline Polygon & 9 & Trees: Forest litter understory : 1 & 9 & 24 & Canarium communae & 4 & 3 & 3 & \\
\hline Potugon & 10 & Trees: Forest litter understory: I & 10 & 20 & Canarium communae & 5 & 3 & 3 & \\
\hline Folugon & 11 & Trees: Forest litter understory: I & 11 & 39 & Canarium communae & 5 & 3 & 3 & \\
\hline Potugon & 12 & Trees: Forest litter understory: \& & 12 & 35 & Canarium communae & 4. & 3. & 3. & \\
\hline Polvgon & 13 & Trees: Forest litter understory: \& & 13 & 31 & Canarium communae & $5:$ & 3. & 3. & \\
\hline
\end{tabular}

Gambar 20 Data atribut pada vegetasi theme 
6. Proses terakhir adalah memperoleh analisa data yang telah dihitung dengan pemodelan CITYgreen, dimana proses tersebut melalui prosedur berikut ini. blok seluruh theme yang sedang diaktifkan, dan mengklik menubar CITYgreen $\rightarrow$ Analyze Data seperti pada gambar 21 berikut ini.

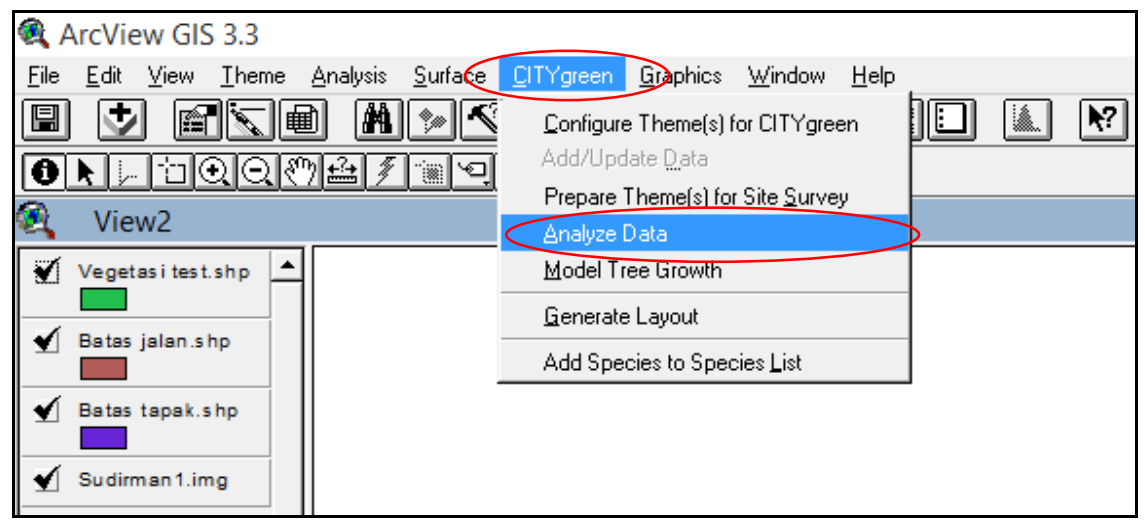

Gambar 21 Perintah memperoleh analisa data dengan CITYgreen 5.2

Pilih batas tapak sebagai Study Area, dan memilih use all records. Kemudian pilih model alternate scenario. Pada View theme pilih semua theme yang aktif dengan cara klik ikon (>) pada semua view theme. Pada menu Analysis pilih carbon storage and secquestration, air quality, dan stormwater runoff. Kemudian pilih lokasi file hasil report disimpan pada lokasi yang tepat, semua yang perlu dipilih disajikan pada Gambar 22 berikut ini.

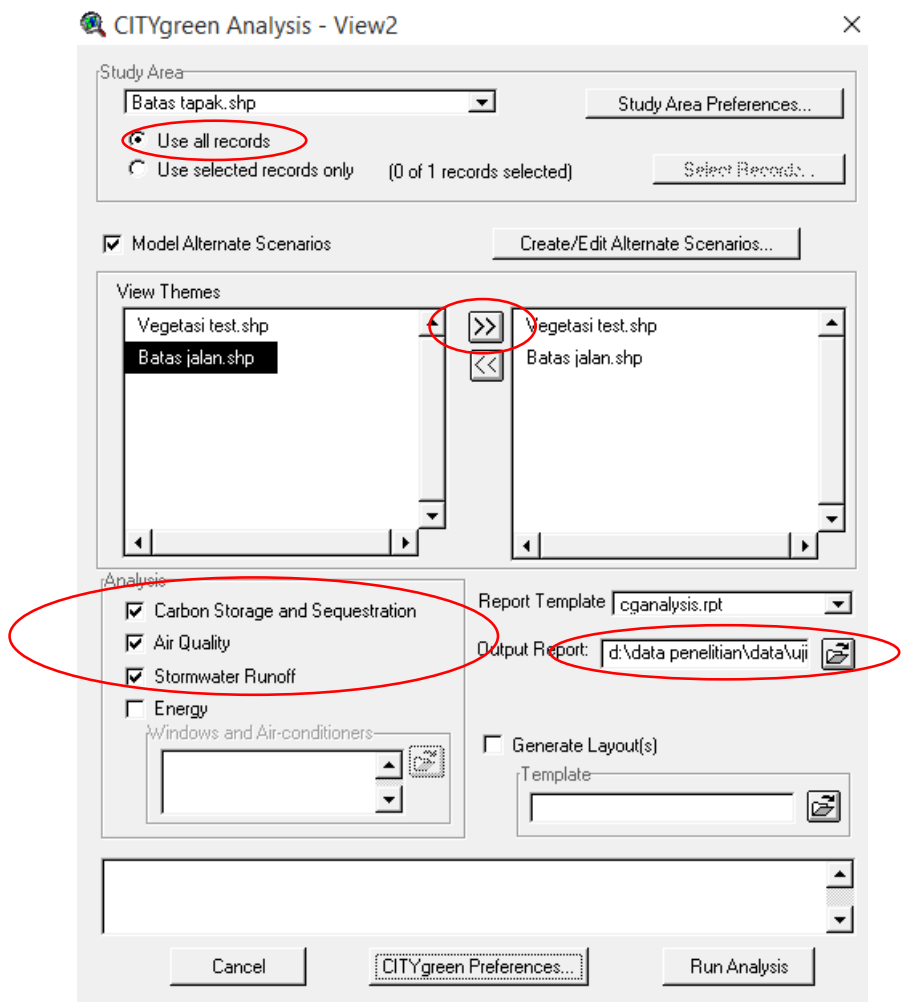

Gambar 22 Kriteria yang perlu diisikan pada jendela CITYgreen Analysis 
Prosedur selanjutnya adalah memilih CITYgreen Preferences sehingga akan muncul jendelanya untuk diisikan kriterianya. Kriteria yang harus diisikan adalah sebagai berikut:

a. Default hydrolic soil group pilih tipe "B" untuk menujukan kondisi tanah yang baik.

b. Default rainfall region pilih tipe “III" karena kota Bogor merupakan kawasan tipe dengan curah hujan tinggi.

c. Default air quality pilih “average 10 cities” untuk menunjukan rata-rata kondisi udara yang ada di 10 kota

d. Default state pilih "Hawaii" karena Hawaii memiliki karakteristik temperatur kawasan yang hampir sama dengan di Kota Bogor.

e. Default slope masukan nilai "0.1" karena lokasi pada penelitian merupakan jalan raya yang kemiringan slope nya tidak signifikan.

f. Default precipitation masukan nilai "0.5" karena curah hujan di Kota Bogor sangat tinggi berkisar antara 2.700-3000 mm/tahun maka dipilih presipitasinya besar.

g. Default annual cooling cost masukan nilai "0" karena kriteria ini berpengaruh pada penilaian penghematan energi, dan kriteria ini tidak masuk dalam kriteria penilaian sehingga diisikan 0 .

h. Default construction cost masukan nilai " 2 " dalam satuan \$USD karena standard pada buku panduan CITYgreen User Manual Book sudah dietapkan.

Senüua yang perlu diisikan disajikan pada Gambar 23 berikut ini, klik kemudian $\mathbf{O K}$ untuk mengakhiri perintah.

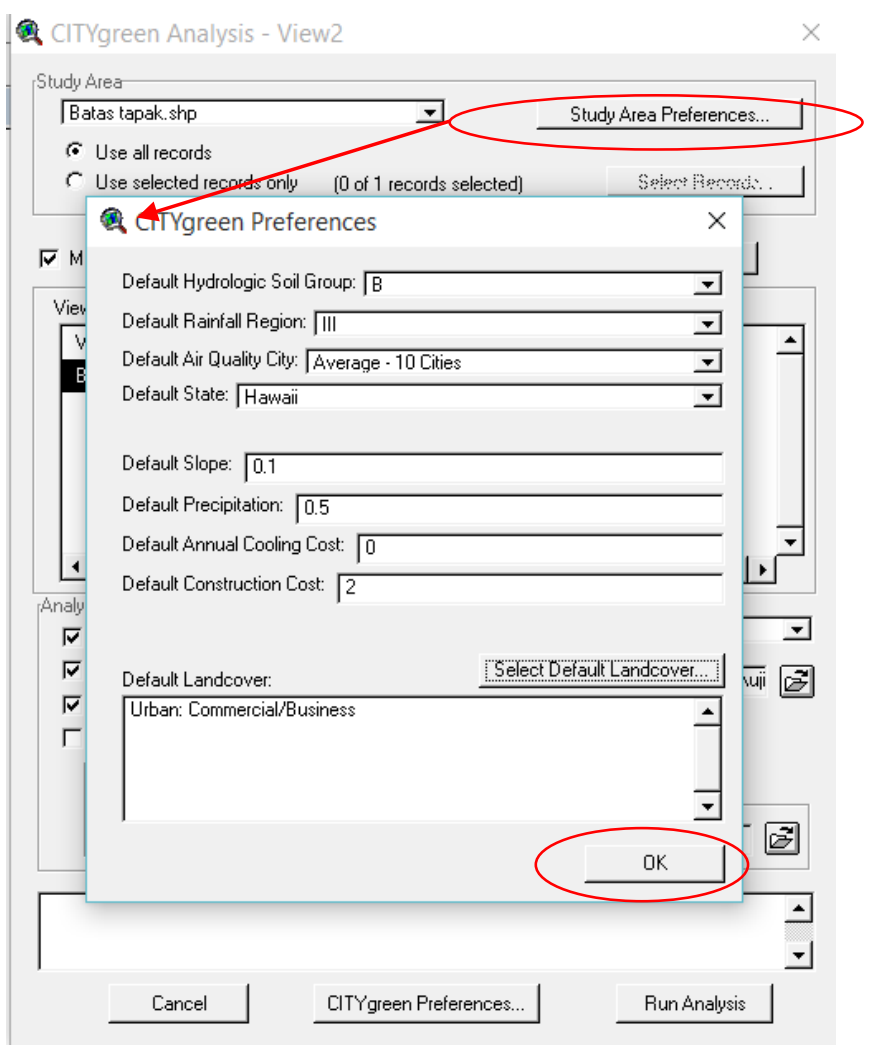

Gambar 23 Kriteria yang perlu diisika pada jendela CITYgreen Preferences 
9. Prosedur selanjutnya adalah memilih CITYgreen Analysis area name field pilih CgFeaure (Feature) dan klik OK untuk mengakhiri seperti pada Gambar 24 berikut ini.

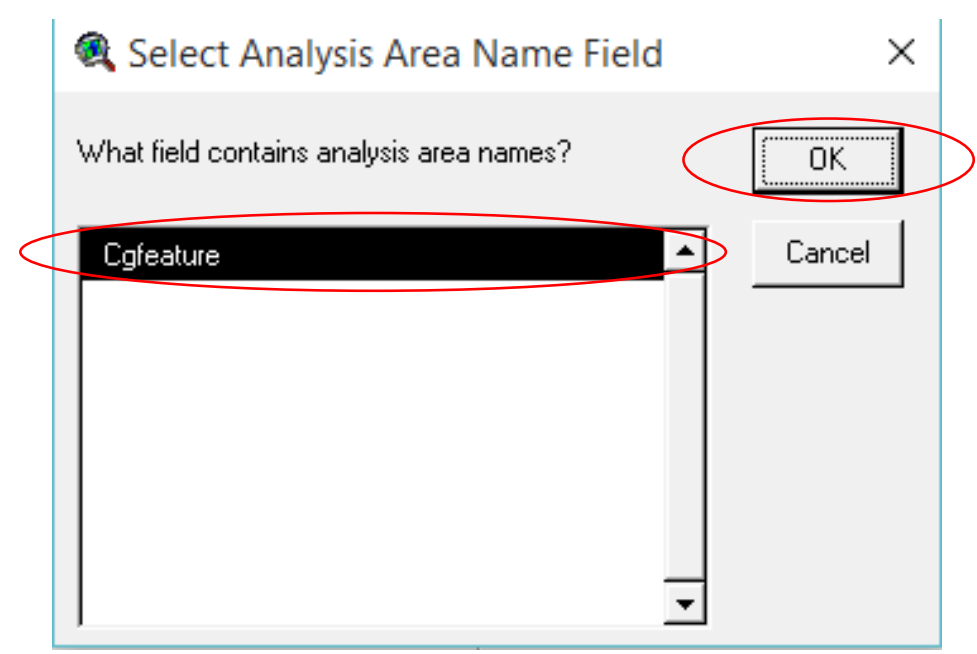

Ga⿳亠㐅⿵冂⿰㐅㐅⿸\zh14𠃋 西 dalam analisis data

耐0. Prosedur terakhir adalah mengklik run analysis pada jendela CITYgreen Analysis untuk memperoleh hasil perhitungan analisis jasa lingkungan pada satu jalan sampel penelitian, ditunjukan dengan jelas pada Gambar 25 berikut ini.

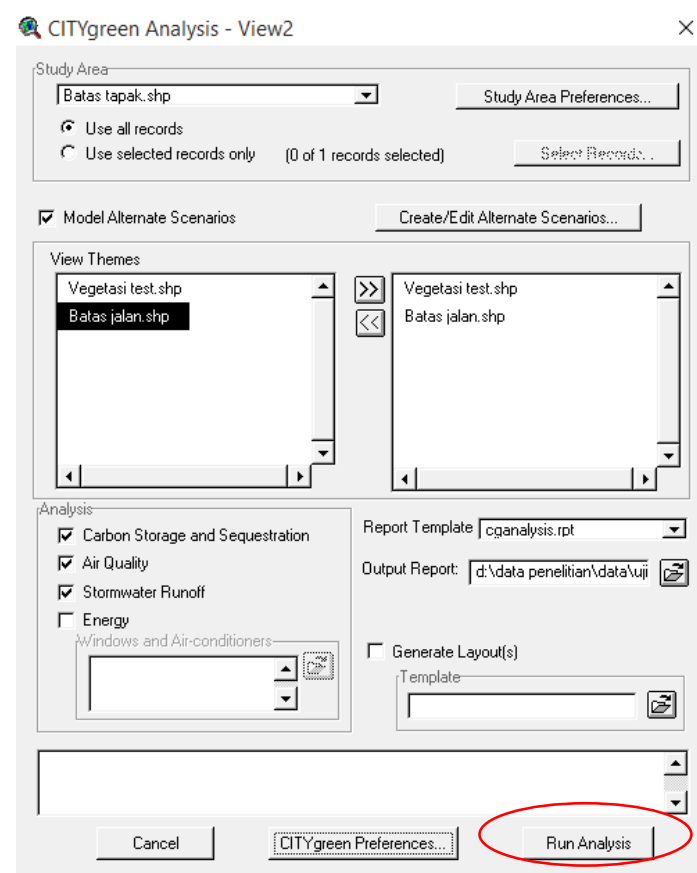

Gambar 25 Proses Run Analysis Data pada CITYgreen 
Contoh hasil analisa data yang telah dilakukan dengan menggunakan perangkat lunak CITYgreen ditunjukan pada Gambar 26 berikut ini.

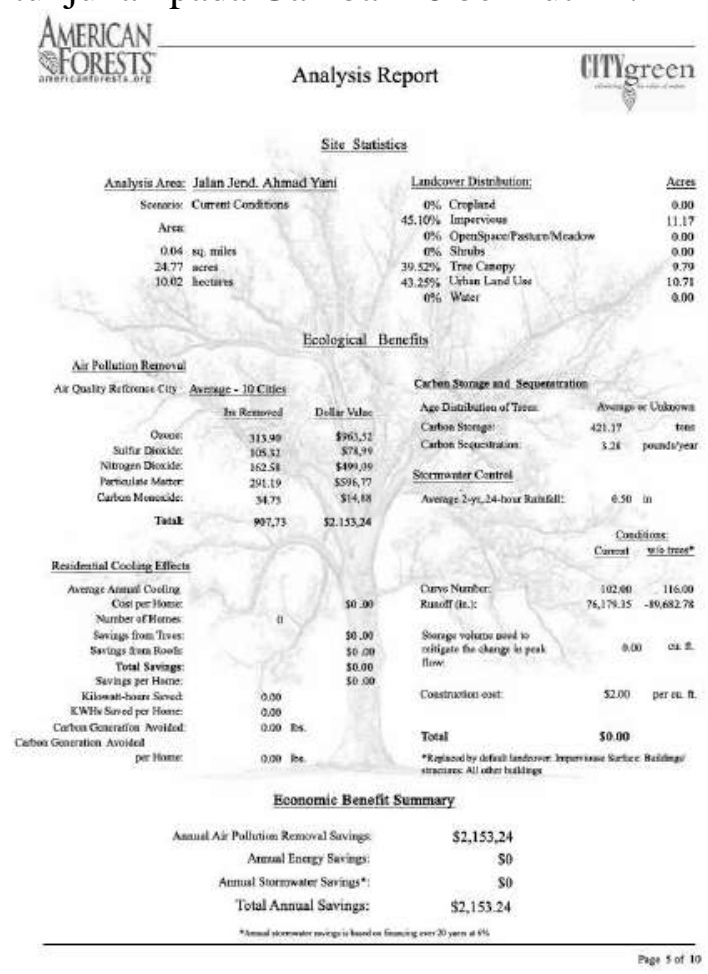

\section{Tahapan Analisis}

Gambar 26 Contoh hasil CITYgreen Analysis report summary

Tahapan analisis merupakan tahapan pengolahan data yang telah diperoleh dari prosês inventarisasi, kemudian data dianalisa dengan cara deskriptif dan spasial. Poses analisis deskriptif diperoleh dari perbandingan data ambien atau kondisi ideal dengan data faktual di lapang, dan perhitungan yang diperoleh dari analisa CकT Ygreen 5.2 ekstensi ArcView 3.3 menggunakan Hawaii sebagai acuan yang dilihat berdasarkan kondisi iklim dan temperatur rata-rata yang identik dengan kondisi temperatur dan klimatologi Kota Bogor (IPCC 2014).

Proses selanjutnya menghitung analisis regresi linier sederhana bivariat, kemudian dilakukan uji korelasi untuk mengetahui hubungan antar variable $x$ dan y, berdasarkan buku Applied Statistics for behavioral (Hinkle et.all. 2003) digunakan persamaan matematis untuk analisis regresi linear sederhana adalah sebagai berikut:

$$
\hat{\mathrm{Y}}=a+\mathrm{bx}
$$

$\hat{Y}=$ Penduga (bagi rata-rata Y untuk X tertentu) Variable terikat (Variable yang diduga)

$\mathrm{X}=$ Variable bebas (Variable yang diketahui)

$\mathrm{a}, \mathrm{b}=$ Penduga parameter A dan B (Koefisien regresi sampel)

$a=$ Intersep (nilai $Y$, jika $\mathrm{X}=0$ )

$\mathrm{b}=\operatorname{slop}$ (Kemiringan garis regresi)

Rumus untuk memperoleh nilai a adalah sebagai berikut:

$$
a=\bar{Y}-b \bar{X}=\frac{\sum_{i} Y i \sum_{i} X i^{2}-\sum_{i} X i \sum_{i} X i Y i}{n \sum_{i} X i^{2}-\left(\sum_{i} X i\right)^{2}}
$$


Dan untuk memperoleh nilai $\mathrm{b}$ dengan menggunakan rumus sebagai berikut:

$$
b=\frac{n \sum_{i} X i Y i-\sum_{i} X i \sum_{i} Y i}{n \sum_{i} X i^{2}-\left(\sum_{i} X i\right)^{2}}
$$

Standar eror regresi merupakan indeks yang digunakan untuk mengukur variasi titik-titik observasi di sekitar garis regresi. Untuk mengetahui nilai estimasi eror digunakan rumus:

$$
S_{x y}=\sqrt{\frac{\sum\left(y^{2}\right)-a\left(\sum y\right)-b\left(\sum x y\right)}{n-2}}
$$

Dengan standar eror, batasan seberapa jauh perkiraan melesetnya dapat diketahui. Bila semua titik observasi berada tepat di garis regresi maka kesalahan baku anak bernilai sama dengan nol. Berarti perkiraan yang dibuat sesuai dengan data sebēnarnya.

Untuk mengetahui koefiisien regresi a dan b (penduga a dan b) menggunakan kesalahan baku dengan rumusnya adalah:

$$
\text { 产 } \frac{3}{\overline{\bar{n}}} \quad S a=\sqrt{\frac{\sum X^{2}-S_{x y}}{n \cdot \sum\left(X^{2}\right)-\left(\sum X\right)^{2}}}
$$

Dankoefisien regresi b (Penduga $b$ ) dengan menggunakan rumus:

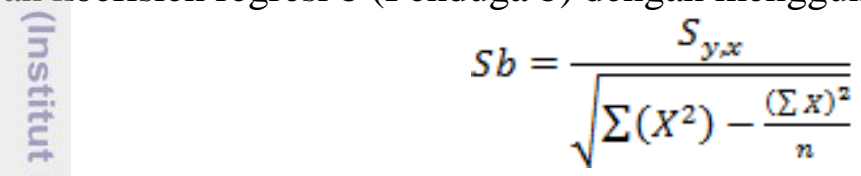

Penduga parameter regresi dari nilai $\alpha$ atau derajat kepercayaan (1- $\alpha)$ yang telah ditentukan, interval pendugaan parameter A dan B dapat ditentukan, yang diberikan masing-masing oleh: $b-\frac{1}{2} S_{b} \leq B \leq b+\frac{t a}{2} S_{b}$ untuk pendugaan interval parameter $\mathrm{B}$, dan

$a \frac{\varrho_{t}}{2} S_{a} \leq A \leq a+\frac{t a}{2} S_{a}$ untuk penduga interval parameter A, dengan derajat kebebasan (n-2). Artinya dengan interval keyakinan 1- $\alpha$ kasus pada interval tersebut akan berisi A atau B yang benar.

Analisis uji korelasi yang dilakukan pada penelitian bertujuan untuk memperoleh koefisien $\left(\mathrm{R}^{2}\right)$ berdasarkan buku Applied Statistics for behavioral (Hinkle et.all. 2003) digunakan persamaan berikut ini:

$$
r x y=\frac{\sum Z x Z y}{n-1}
$$

Keterangan:

$$
\begin{aligned}
& r x y=\text { Koefisien korelasi } \mathrm{x} \text { dan } \mathrm{y} \\
& \sum^{Z x Z y}=\text { Jumlah } \mathrm{Zx} \text { dikalikan } \mathrm{Zy}
\end{aligned}
$$

Dimana $Z x=\frac{x}{S x} \operatorname{dan} Z y=\frac{y}{S y}$

$n-1=$ Jumlah banyaknya individu dikurangi 1

Dimana s merupakan standar deviasi digunakan persamaan berikut ini:

$$
s x=\sqrt{\frac{\sum x^{2}}{n-1}} \text { dan } s y=\sqrt{\frac{\sum y^{2}}{n-1}}
$$


Setelah itu substitusikan nilai Zx dan Zx dengan persamaan berikut ini:

\section{Tahapan Rekomendasi}

$$
r x y=\frac{\sum x y}{\sqrt{\sum x^{2} \sum y^{2}}}
$$

근 Tahapan rekomendasi merupakan tahap perumusan ide yang diharapkan dapat ? menanggulangi masalah yang diketahui dari hasil proses analisa. Hasil rekomendasi ini diharapkan menjadi bahan acuan bagi pemerintah Kota Bogor dalam melakukan penataan lanskap yang sesuai dengan fungsi ekologisnya. Rekomendasi yang ingin dicapai adalah pohon apa saja yang mampu mereduksi polusi udara dalam bentuk gas dan partikel, kemuidan keseuaian pohon jika dilakukan penambahan pada lokasi penelitian, dan seberapa evektif peningkatan reduksi polusi yang diperoleh. Metode yang dilakukan untuk dapat memperoleh rekomendasi tersebut melalui penilaian kriteria pohon penyerap polusi udara dalam beñituk gas dan kriteria pohon penjerap polusi udara dalam bentuk partikel dimana metode tersebut dijelaskan lebih rinci pada subbab metode skor pohon pereduksipolusi udara berikut ini.

\section{Metode Skor Pohon Pereduksi Polusi Udara}

Metode skor pohon pereduksi polusi udara merupakan proses terakhir untuk menentukan vegetasi yang sesuai untuk digunakan sebagai rekomendasi dalam pe⿳亠二⿵冂⿱八口𧘇ggulangan masalah polusi udara dengan metode analisa skor kriteria pohon penyerap polusi gas, dan penyerap partikel berdasarkan skripsi Al-Hakim pada tahum 2014 yang telah dimodifikasi. Kriteria ini dibedakan menjadi kriteria umum dan kriteria khusus. Kriteria umum terdiri dari kriteria pohon penyerap polusi dălam bentuk gas, dan kriteria pohon penjerap polusi dalam bentuk partikel, Remudian kriteria khususnya adalah kriteria pohon pada jalur hijau jalan. Kriteria yäng digunakan disajikan secara lengkap dalam Tabel 8 berikut ini.

Tabel 8 Kriteria umum dan khusus pohon pereduksi polusi

\begin{tabular}{ll}
\hline \multicolumn{1}{c}{} & \multicolumn{1}{c}{ Kriteria Umum Pohon Penyerap Polusi Gas } \\
\hline A1 & Kepadatan tajuk $^{1}$ \\
A2 & Daun tipis $^{2}$ \\
A3 & Jumlah daun banyak $^{3}$ \\
\hline
\end{tabular}

A3 Jumlah daun banyak

\section{Kriteria Umum Pohon Penjerap Polusi Partikel}

B1 berbulu/bertrikoma $)^{4}$

B2 Daun jarum/ daun lebar ${ }^{5}$

B3 Kepadatan tajuk ${ }^{6}$

B4 Tekstur kulit batang dan ranting kasar, ranting berduri ${ }^{7}$

B5 kepadatan ranting ${ }^{8}$

\section{Triteria Khusus Pohon Pada Jalur Hijau Jalan ${ }^{9}$}

C1) Tidak mudah gugur daun (evergreen)

(2) Unity dengan kondisi tapak

(4) Tidak membahayakan

C4 Mudah perawatan

Sumber: Carpenter et al $(1975)^{4}$, Dahlan $(1989)^{4,7,8}$, Fakuara (1986) $)^{1,3,4}$, Hermawan $(2011)^{4,5,6}$, Nugrahani $(2006)^{2}$, dan Taihuttu $(2001)^{5}$ dalam Al-Hakim 2014 yang telah dimodifikasi, dan Agustini (1994) ${ }^{9}$

Dimana nilai 1 = Tidak sesuai; 2 = Kurang sesuai; $3=$ Sesuai; dan $4=$ Sangat sesuai . 
Prosedur menggunakan kriteria yang tersaji pada Tabel 8 melalui beberapa prosedur sebagai berikut:

1. Menyiapkan data rekapitulasi jenis pohon dari setiap jalan pada Ms. Excel,

2. Membagi data menjadi dua tipe penilaian penyerap polusi dalam bentuk gas, dan penjerap polusi dalam bentuk parkikel (sebaiknya dipisahkan dalam sheet yang berbeda agar tidak tertukar) yang merupakan kriteria umum,

3. Menambahkan kriteria khusus yaitu kesesuaian pohon jalur hijau jalan pada setiap kriteria umum, sehingga akan dihasilkan penilaian yang lebih akurat,

4. Menghitung jumlah skor penilaian pada setiap individu pohon

5. Memasukan presentase kesesuaian pohon dengan menggunakan rumus presentase kesesuaiannya dengan rumus perhitungan sebagai berikut:

Presentase kesesuaian $=\frac{\text { Jumlah skor kriteria penilaian }}{\text { Jumlah total skor ideal }} \times 100 \%$

Hasil presentase kesesuaian kemudian dikategorikan menjadi 4 kelompok kesesuaian dengan kriteria sangat sesuai dengan rentang $>80 \%$, sesuai dengan rentang $61-80 \%$, kurang sesuai $41-60 \%$, dan tidak sesuai dengan rentang $\leq 40 \%$. (Hidayat 2008). 


\section{HASIL DAN PEMBAHSAN}

\section{Kondisi Umum Lokasi}

Secara umum Kota Bogor berada pada $106^{\circ} 48^{\prime}$ BT dan $6^{\circ} 36^{\prime}$ LS. dengan jarak $\pm 56 \mathrm{Km}$ dari Ibu Kota Jakarta. Wilayah Administrasi Kota Bogor terdiri atas 6 kecamatan dan 68 kelurahan, dengan luas wilayah keseluruhan 11.850 ha. Secara administratif, wilayah Kota Bogor berbatasan langsung dengan; Sebelah Utara: berbatasan dengan Kecamatan Kemang, Bojong Gede, dan Kecamatan Sukaraja Kabupaten Bogor; Sebelah Timur: berbatasan dengan Kecamatan $\sqsubseteq$ Sukaraja dan Kecamatan Ciawi Kabupaten Bogor; Sebelah Barat: berbatasan dengan Kecamatan Dramaga dan Kecamatan Ciomas Kabupaten Bogor; Sebelah Selatan: Gerbatasan dengan Kecamatan Cijeruk dan Kecamatan Caringin Kabupaten Bogor.

Cürah hujan rata-rata di wilayah Bogor berkisar 2600-2700 mm/tahun. Temperatur rata-rata berkisar antara $26^{\circ} \mathrm{C}$ sampai dengan $40^{\circ} \mathrm{C}$, dengan kelembaban udara $\pm 70 \%$ (BMKG 2015). Kelembaban udara dipengeruhi oleh keberadaā̄ pohon. Pohon-pohon yang terdapat di jalan-jalan arteri Bogor berjumla $\bar{\Gamma} 4.640$ pohon yang terdiri dari 4.428 pohon sehat, dan 212 pohon yang berpenyakit (Dinas Kebersihan dan Pertamanan 2015).

Jafan yang diamati dalam penelitian ini adalah jalan arteri sekunder yang terdapat di Kota Bogor, yaitu JL. Ir. H. Djuanda, JL. Jendral Sudirman, JL. Pemuda, JL. Raya Pajajaran, JL. Jalak Harupat, JL. R.E Martadinata, JL. Ahmad Yani, JL Otto Iskandardinata, JL. Raya Empang, dan JL. Dadali sebagai mana yang terihat pada Tabel 8. Alasan pemilihan 10 lokasi ini adalah karena merupakan jalan protokol di Kota Bogor yang termasuk dalam kategori jalan Arteri Primer dan Sekunder sehingga frekuensi lintas kendaraan bermotor sangat tinggi. Seperti yang telah diketahui sebelumnya bahwa frekuensi kendaraan yang melintas cinggi pada suatu jalan akan mengeluarkan emisi kendaraan yang besar pula. Oleh karena itu, pentingnya dilakukan rekayasa tata hijau untuk bisa menanggulangi masalah tersebut.

Tabel 9 Daftar 10 jalan sampel penelitian di Kota Bogor

\begin{tabular}{lll}
\hline NO & KARAKTERISTIK JALAN & FOTO \\
\hline 1. JL. Ir. H. Djuanda & Panjang $=581 \mathrm{~m}$ \\
Lebar badan jalan $=16 \mathrm{~m}$ & \\
Lebar Trotoar Kiri $=2.1 \mathrm{~m}$ & \\
Lebar Trotoar Kanan $=1.5 \mathrm{~m}$ & \\
Kategori Jalan : Jalan Arteri & \\
Sekunder & \\
0 &
\end{tabular}


2. JL. Jendral Sudirman

Panjang $=1.286 \mathrm{~m}$

Lebar badan jalan $=15 \mathrm{~m}$

Lebar Trotoar Kiri $=1.5 \mathrm{~m}$

Lebar Trotoar Kanan $=1.5 \mathrm{~m}$

Kategori Jalan : Jalan Arteri

Sekunder

\section{JL. Pemuda \\ Panjang $=1950 \mathrm{~m}$}

Lebar badan jalan $=9 \mathrm{~m}$

Lebar Trotoar Kiri $=0 \mathrm{~m}$

Lebar Trotoar Kanan $=1.5 \mathrm{~m}$

Kategori Jalan : Jalan Arteri

3. Sekunder

4. $\overline{\bar{s}}$ JL. Raya Pajajaran

Panjang $=6.400 \mathrm{~m}$

Lebar badan jalan $=24.2 \mathrm{~m}$

Debar Trotoar Kiri $=1 \mathrm{~m}$

(7) Lebar Trotoar Kanan $=1 \mathrm{~m}$

ㄱ. Kategori Jalan : Jalan Arteri

Primer

ए

0

$\stackrel{\circ}{ }$

\section{JL. Jalak Harupat}

Panjang $=1.020 \mathrm{~m}$

Lebar badan jalan $=9 \mathrm{~m}$

Lebar Trotoar Kiri $=2 \mathrm{~m}$

Lebar Trotoar Kanan $=2 \mathrm{~m}$

Kategori Jalan : Jalan Arteri

Sekunder
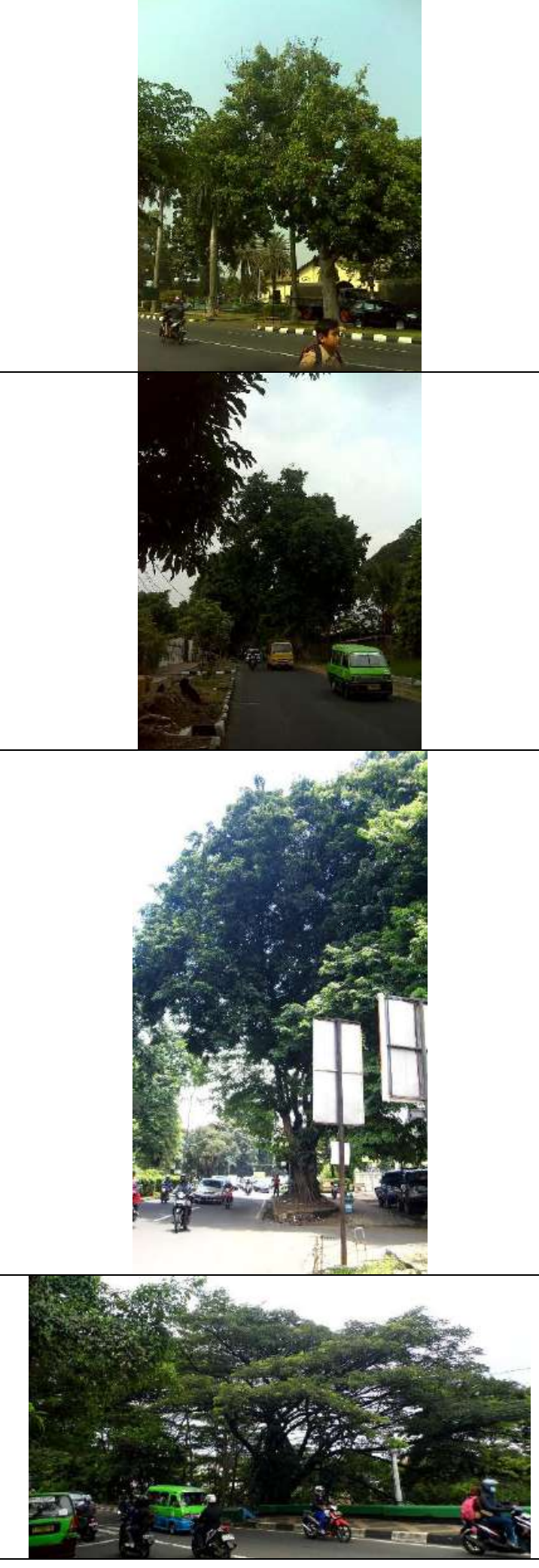


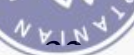

Lanjutan Tabel 9 Daftar 10 jalan sampel penelitian di Kota Bogor

6. JL. R.E Martadinata

Panjang $=1.060 \mathrm{~m}$

Lebar badan jalan $=9 \mathrm{~m}$

Lebar Trotoar Kiri $=1 \mathrm{~m}$

Lebar Trotoar Kanan $=1 \mathrm{~m}$

Kategori Jalan : Jalan Arteri

Sekunder

7. JL. Ahmad Yani

Panjang $=2.111 \mathrm{~m}$

Lebar badan jalan $=9 \mathrm{~m}$

Lebar Trotoar Kiri $=1.5 \mathrm{~m}$

Lebar Trotoar Kanan $=1.5 \mathrm{~m}$

Kategori Jalan: Jalan Arteri

Sekander

8. JL. Qtto Iskandardinata

Panjäng $=1.184 \mathrm{~m}$

Lebât badan jalan $=10 \mathrm{~m}$

Lebar Trotoar Kiri $=1 \mathrm{~m}$

Lebär Trotoar Kanan $=1 \mathrm{~m}$

Kategori Jalan: Jalan Arteri

Sekunder

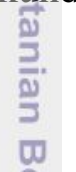

9. JL. Raya Empang

Panjang $=250 \mathrm{~m}$

Lebar badan jalan $=9 \mathrm{~m}$

Lebar Trotoar Kiri $=1 \mathrm{~m}$

Lebar Trotoar Kanan $=1 \mathrm{~m}$

Kategori Jalan: Jalan Arteri

Sekunder
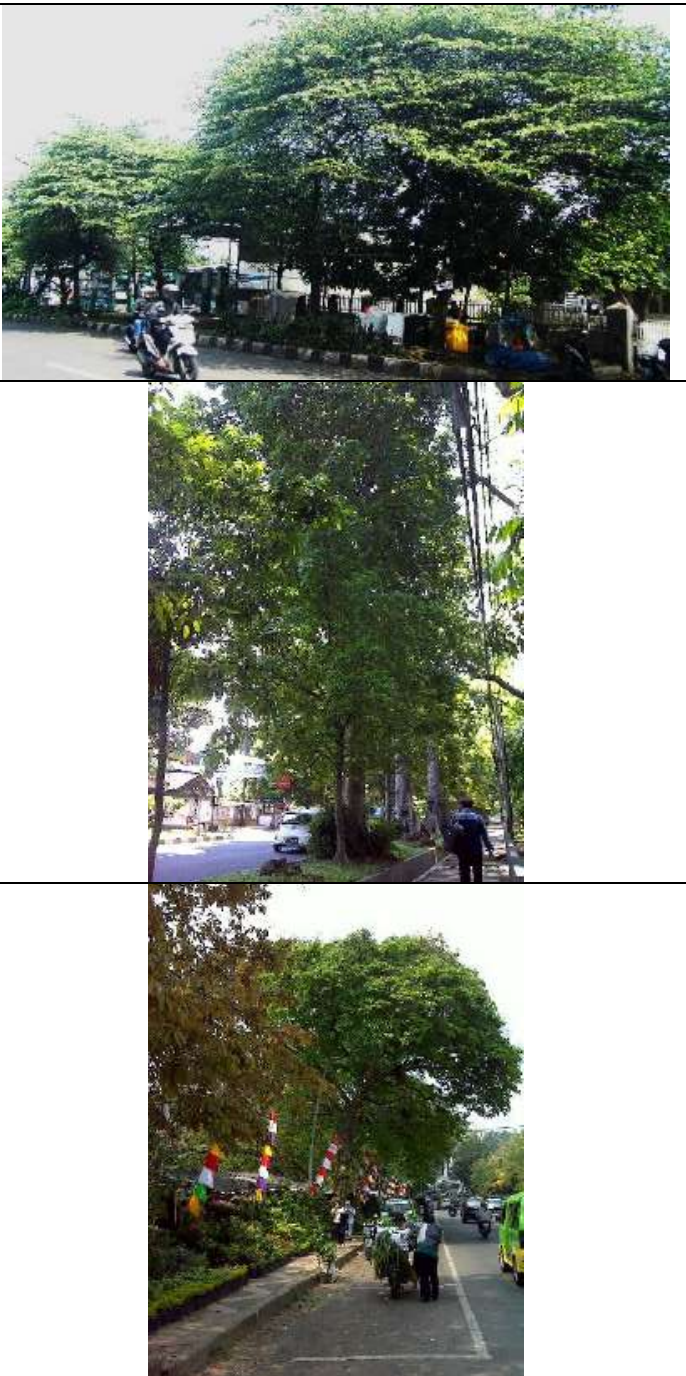

10. JL. Dadali

Panjang $=1.040 \mathrm{~m}$

Lebar badan jalan $=9 \mathrm{~m}$

Lebar Trotoar Kiri $=1 \mathrm{~m}$

Leban Trotoar Kanan $=1 \mathrm{~m}$

Kategori Jalan : Jalan Arteri

Selkunder
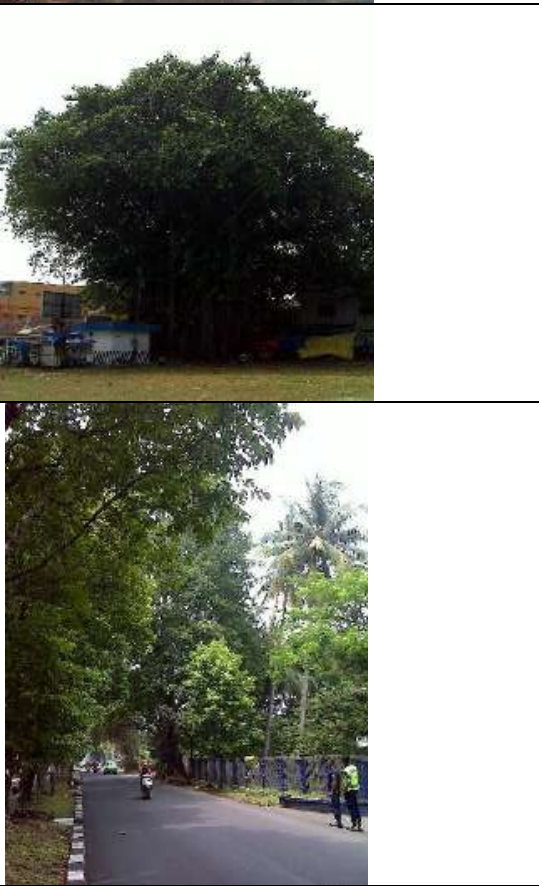


\section{Kondisi jalan dan transportasi di Kota Bogor}

Kondisi semua jalan di Kota Bogor sudah diaspal dan dapat dilintasi kendaraan kecil maupun besar. Kondisi jalan yang ada saat ini belum merata masih terkonsentrasi pada ring utama kota yang melintasi pusat kota. Dengan aktivitas utama terkonsentrasi pada pusat kota dan bentuk jaringan jalan yang belum merata maka kemacetan lalu lintas pada jalan utama Kota Bogor tidak terelakan. Kondisi jaringan jalan eksisting berdasarkan kelompok fungsinya yang terdapat di Kota Bogor terdiri dari jalan arteri primer, arteri sekunder, kolektor sekunder, Lokal primer, lingkungan primer dan lingkungan sekunder. Sistem jaringan jalan di Kota Bogor mempunyai pola radial konsentris dengan karakteristik sebagai berikut:

1. Pada kawasan pusat kota terdapat jaringan jalan melingkar (ring) yang mengelilingi Kebun Raya Bogor (ring) yang merupakan gabungan dari ruas Jalan Juanda, Jalan Otista, sebagian Jalan Raya Pajajaran dan Jalan Jalak Harupat.

Jaringan jalan yang berasal dari kawasan lainnya terhubung secara konsentris ke jaringan jalan melingkar ini; beberapa ruas jalan tersebut diantaranya adalah Jalan Suryakencana, Jalan Sudirman, Jalan Raya Pajajaran, Jalan Veteran, Jalan kapten Muslihat serta Jalan Raya Empang. Pada bagian Timur Kota Bogor yang berbatasan dengan Kabupaten Bogor, terdapat jalan Tol Jagorawi, yang menghubungkan pusat kota Bogor dengan Ciawi serta dengan Jakarta maupun daerah lainnya.

Pada bagian Utara Kota Bogor (Kecamatan Tanah Sareal dan Bogor Barat) terdapat jalan lingkar (ring road). Jalan lingkar ini menghubungkan Jalan Sindang Barang (di Kecamatan Bogor Barat) dengan Jalan Raya Bogor (di Kecamatan Tanah Sareal).

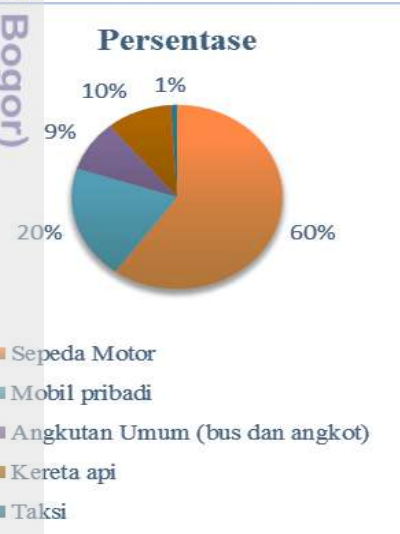

Jumlah Kendaraan Bermotor Di Kota Bogor

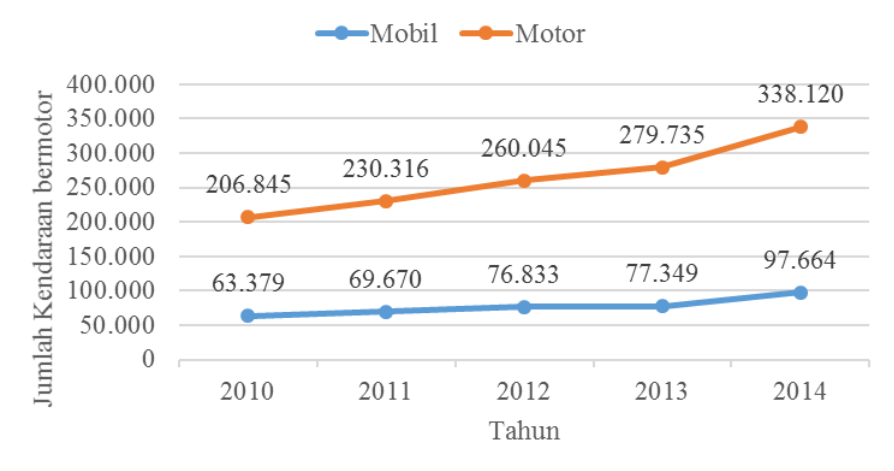

Gambar 27 Presentase jenis kendaraan bermotor (Kiri) dan jumlah kendaraan bermotor di Kota Bogor (Kanan)

(Sumber: Dinas LLAJ Kota Bogor, 2015)

Adapun sarana transportasi masyarakat kota Bogor meliputi sepeda motor $(60 \%)$, mobil pribadi (20\%), angkutan umum (9\%). Khusus untuk kereta api, dapat menjangkau Jabodetabek dengan frekuensi perjalanan sekitar setiap lima menit, Selain itu jumlah kendaraan di Kota Bogor bertambah setiap tahunnya. 
Kenaikan jumlah kendaraan sepeda motor meningkat sangat signifikan tiap tahunnya, dibuktikan dengan data yang tersaji pada Gambar 27 sebelah kanan untuk sepeda motor bentuk grafik curam, sedangkan untuk grafik kenaikan mobil T bentuk grafik yang landai menunjukan peningkatan yang tidak terlalu signifikan.

Kenaikan jumlah kendaraan bermotor tiap tahunnya menyebabkan konsentrasi polutan di udara terus meningkat, sehingga perlunya dilakukan penelitian ini.

\section{Kondisi emisi di Kota Bogor}

Kondisi emisi di Kota Bogor disebabkan salah satunya bersumber dari gas buang kendaraan bermotor. Hasil uji emisi yang dilakukan dibedakan dari jenis 동 konsumsi bahan bakarnya yaitu kendaraan bermotor yang menggunakan bensin 을 kendaraan bermotor yang menggunakan solar. Volume emisi kendaraan bensin tertinggi terjadi pada tahun 2013 yaitu 332 ppm, dan terjadi penurunan $\sqsubset$ pada tahum 2014 menjadi 283, sedangkan pada tahun 2012 dan 2014 merupakan puncak emisi kendaraan solar dimana data tersaji secara lebih lengkap pada Gambar 28 (BPLH 2015).

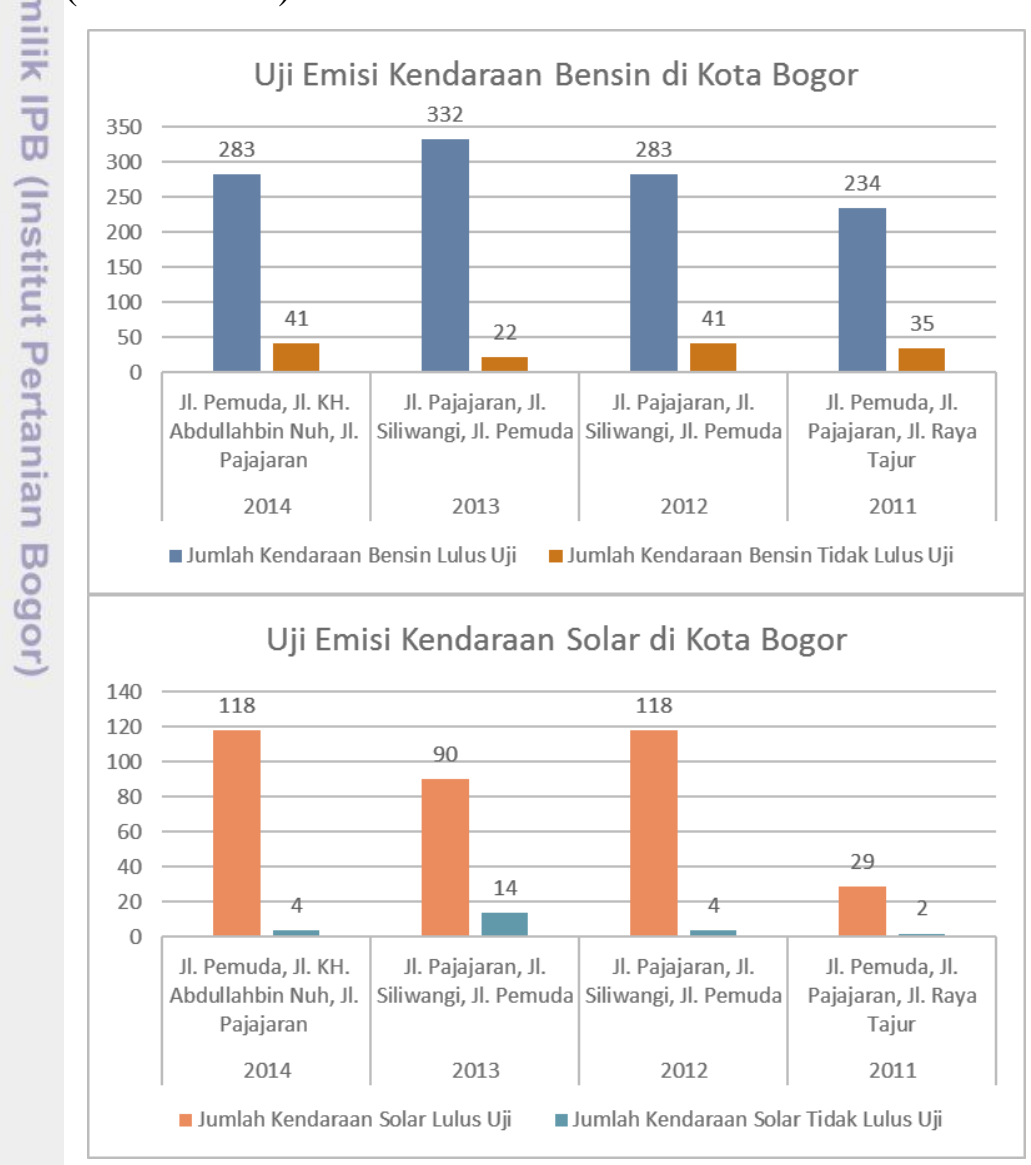

Gambar 28 Diagram uji emisi kendaraan bermotor yang menggunakan bensin (atas), dan solar (bawah) di Kota Bogor

(Sumber: Laporan GRK 2015 BPLH Kota Bogor, 2015) 
Baku mutu atau batas ambien emisi polusi udara sesuai PP No 41 Tahun 1999 tentang Pengendalian Udara yang diizinkan ada sebesar $235 \mu \mathrm{m} / \mathrm{Nm}^{3}$ untuk $\mathrm{O}_{3}, 365 \mu \mathrm{m} / \mathrm{Nm}^{3}$ untuk $\mathrm{SO}_{2}, 150 \mu \mathrm{m} / \mathrm{Nm}^{3}$ untuk $\mathrm{NO}_{2}, 230 \mu \mathrm{m} / \mathrm{Nm}^{3}$ untuk PM10, dan $1.000 \mu \mathrm{m} / \mathrm{Nm}^{3}$ untuk CO. Kondisi emisi yang tercatat sejak tahun 2011-2014 tersaji dalam Tabel 10, dimana kondisi polusi rata-rata per tahun polutan debu, $\mathrm{NO}_{2}, \mathrm{O}_{3}$, dan $\mathrm{SO}_{3}$ masih di bawah batas ambang yang artinya masih dalam batas toleransi, namun pada polutan $\mathrm{CO}$ sudah berada diatas batas ambang, sehingga perlu adanya rekayasa tata hijau untuk menanggulangi masalah tersebut.

Karbon monoksida (CO) sendiri berasal dari gas buang kendaraan bermotor karena pembakaran yang tidak sempurna. Gas CO sangat berbahaya bagi kesehatan dan secara umum dikategorikan sebagai asphyxiant yaitu zat dapat menyebabkan kematian jika terhirup dalam konsentrasi besar. (Rao 1994)

Tabel 10 Kondisi emisi rata-rata tahun 2011-2014 di Kota Bogor

\begin{tabular}{|c|c|c|}
\hline$\stackrel{\rho}{\frac{\rho}{0}}$ POLUTAN & BAKU MUTU $\left(\mu \mathrm{M} / \mathrm{NM}^{3}\right)$ & RATA-RATA/TAHUN $\left(\mu \mathrm{M} / \mathrm{NM}^{3}\right)$ \\
\hline Debu, PM & 230,00 & 152,59 \\
\hline Karbon Monooksida, CO & $1.000,00$ & $\mathbf{1 . 8 3 8 , 0 7}$ \\
\hline Niťrogen Dioksida, $\mathrm{NO}_{2}$ & 180,00 & 52,50 \\
\hline Oksidan, $\mathrm{O}_{3}$ & 235,00 & 34,46 \\
\hline Sulfur Dioksida, $\mathrm{SO}_{2}$ & 365,00 & 43,75 \\
\hline
\end{tabular}

Sumber: BPLH 2015

\section{Identifikasi Jenis Vegetasi}

Total keseluruhan pohon yang diamati berjumlah 1.497 pohon dengan jumilah terbanyak adalah pada Jl. Raya Pajajaran berjumlah 789 pohon, dan junfiah paling sedikit adalah pada Jl. Otto Iskandar Dinata yang berjumlah 8 pohōn saja, hal ini dikarenakan banyak pohon yang ditebang akibat proyek pelebaran jalur pedestrian dan pembuatan proyek kolom 9 lawang oleh pengerintah Kota Bogor. Jl. Jendral Sudirman sebanyak 32 pohon, Jl. R.E. Mactadinata sebanyak 101 pohon, Jl. Pemuda sebanyak 84 pohon, Jl. Ir. H. Djuanda sebanyak 52 pohon, Jl. Jendral Ahamd Yani 230 pohon, Jl. Jalak Harupat sebanyak 95 pohon, Jl. Raya Empang sebanyak 26 pohon, dan J1. Dadali sebanyak 80 pohon. Data jumlah pohon lebih lengkapnya disajikan pada Tabel 11 berikut ini.

Tabel 11 Rekapitulasi jumlah pohon yang diamati pada 10 sampel jalan penelitian

\begin{tabular}{lc}
\hline Nama Jalan & Jumlah pohon sampel \\
\hline JL. Sudirman & 32 \\
JL. R. E. Martadinata & 101 \\
JL. Pemuda & 84 \\
JL. Otto Iskandar Dinata & 8 \\
JL. Ir. H. Djuanda & 52 \\
JL. Jendral Ahmad Yani & 230 \\
JL. Jalak Harupat & 95 \\
JL. Raya Empang & 26 \\
JL. Dadali & 80 \\
JL. Raya Pajajaran & 789 \\
\hline Total Keseluruhan & $\mathbf{1 4 9 7}$ \\
\hline
\end{tabular}




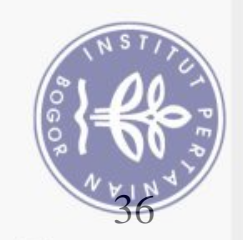

Berdasarkan data yang diperoleh dari pengamatan langsung dilapang, jenis pohon yang mendominasi pada 10 sampel jalan penelitian adalah pohon mahoni I (Swietenia mahogany) berjumlah 720 pohon, dan diurutan kedua adalah pohon kenari (Canarium communae) yang berjumlah 379 pohon. Data lebih lengkapnya disajikan pada Gambar 24 berikut ini.

Rekapitulasi Jumlah Pohon pada 10 Sampel Jalan Penelitian

$$
\text { - Series1 }
$$

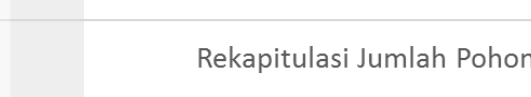

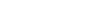
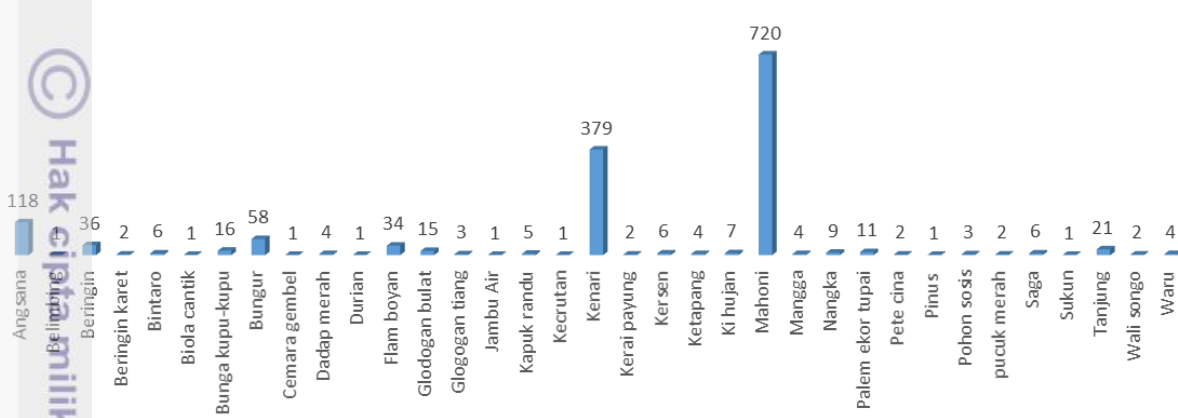

Gambar 29 Diagram Rekapitulasi Jumlah Pohon pada 10 Sampel Jalan Penelitian Identifikasi pohon pada Jl. Jendral Sudirman

Presentase pohon yang mendominasi pada Jl. Jendral Sudirman adalah Bungur (Eangerstromia speciosa) dan Flamboyan (Delonix regia) sebanyak 22\%, Kenari (Ganarium commuane) sebanyak 19\%, Mahoni (Swietenia mahogani) dan Waru (Hî̉iscus tiliaceus) sebanyak 13\%, dan Beringin (Ficus benjamina), Biola cantik (Ficus lyrata), Jambu air (Syzygium samarangense), dan Nangka (Artocarpus heterophyllus) masing-masing 13\%. Data yang lebih lengkapnya lagi disajikan pada Tabel 12. Karakter lanskap jalan yang terbentuk karena dominasi vegetasi tersebut adalah bernuansa keunguan apabila pohon bungur sedang berbunga, dan diselingi warna merah apabila pohon flamboyan sedang berbunga.

Tabel 12 Presentase jumlah pohon pada Jl. Jendral Sudirman

\begin{tabular}{llcc}
\hline Nama Lokal & Nama Latin & Jumlah & Presentase \\
\hline Beringin & Ficus benjamina & 1 & $3 \%$ \\
Biola cantik & Ficus lyrata & 1 & $3 \%$ \\
Bungur & Langerstromia speciosa & 7 & $22 \%$ \\
Flamboyan & Delonix regia & 7 & $22 \%$ \\
Jambu Air & Syzygium samarangense & 1 & $3 \%$ \\
Kenari & Canarium commuane & 6 & $19 \%$ \\
Mahoni & Swietenia mahogani & 4 & $13 \%$ \\
Nangka & Artocarpus heterophyllus & 1 & $3 \%$ \\
Waru & Hibiscus tiliaceus & 4 & $13 \%$ \\
\hline & TOTAL & $\mathbf{3 2}$ & $\mathbf{1 0 0 \%}$ \\
\hline
\end{tabular}

Identifikàsi pohon pada Jl. R. E. Martadinata

Presentase jumlah pohon pada J1. R.E. Martadinata didominasi oleh pohon Bungur (Eangerstromia speciose) sebanyak 48\%, pohon lainnya adalah Kenari 
(Canarium commuane) sebanyak 30\%; Bunga Kupu-kupu (Bauhinia purpurea) sebanyak 7\%; Kersen (Muntingia calabura) sebanyak 5\%; Angsana (Petrocarpus indicus), Beringin (Ficus benjamina), dan Mangga (Mangifera indica) sebanyak 2\%; terakhir Durian (Durio zibethinus) dan Flamboyan (Delonix regia) sebanyak 1\%. Data lebih lengkapnya ditampilkan pada Tabel 13 berikut ini.

Tabel 13 Presentase jumlah pohon pada Jl. R.E. Martadinata

\begin{tabular}{|c|c|c|c|}
\hline Nama Lokal & Nama Latin & Jumlah & Presentase \\
\hline Angsana & Petrocarpus indicus & 2 & $2 \%$ \\
\hline Beringin & Ficus benjamina & 2 & $2 \%$ \\
\hline Bunga Kupu-Kupu & Bauhinia purpurea & 7 & $7 \%$ \\
\hline Bungur & Langerstromia speciosa & 49 & $49 \%$ \\
\hline Durian & Durio zibethinus & 1 & $1 \%$ \\
\hline Flamboyan & Delonix regia & 1 & $1 \%$ \\
\hline Kenari & Canarium commuane & 30 & $30 \%$ \\
\hline Kersen & Muntingia calabura & 5 & $5 \%$ \\
\hline Mangga & Mangifera indica & 2 & $2 \%$ \\
\hline Nangka & Artocarpus heterophyllus & 1 & $1 \%$ \\
\hline \multirow[t]{2}{*}{ Saga } & Adenanthera pavonina & 1 & $1 \%$ \\
\hline & OTAL & 101 & $100 \%$ \\
\hline
\end{tabular}

Karakter lanskap pada jalur hijau jalan yang dibentuk dari dominasi pohon bungur yang diselingi oleh pohon kenari dan pohon bunga kupu-kupu adalah berwarna keunguan apabila pohon bungur dan pohon bunga kupu-kupu sedang berbunga. Selain itu kanopi yang terbentuk sudah sangat lebar sehingga jalur jalan terasa teduh.

\section{Identifikasi pohon pada Jl. Ahmad Yani}

Presentase jumlah pohon pada Jl. Jendral Ahmad Yani didominasi oleh pohơn Kenari (Canarium communae) sebanyak 90\%, pohon lainnya adalah Beringin (Ficus benjamina) sebanyak 5,2\%; Mahoni (Swietenia mahogani) sebânyak 3,9\%; terakhir Cemara gembel (Cupressus papuana), dan Petai cina (Leücaena leucephala) sebanyak $0.4 \%$. Data lebih lengkapnya ditampilkan pada Tabel 14 berikut ini. Karakter lanskap pada jalur hijau jalan yang dibentuk dari dominasi pohon kenari adalah evergreen atau selalu hijau, karena pohon kenari pada iklim Kota Bogor adalah tanaman yang hijau sepanjang tahun. Selain itu kanopi yang terbentuk sudah sangat lebar sehingga jalur jalan terasa teduh, namun karena lebar jalan yang sempit hanya 9 meter sedangkan diameter penutupan kanopi pohon sudah melebihi 10 meter di kanan dan kiri jalur hijau jalan, maka ada beberapa tempat yang sangat gelap. Kondisi pohon yang sudah tua meyebabkan seringnya ranting yang rapuh dan patah saat terjadi hujan oleh karena itu harus berhati-hati apabila akan melintasi jalan ini.

Tabel 14 Presentase jumlah pohon pada Jl. Jendral Ahmad Yani

\begin{tabular}{llcc}
\hline Nama Lokal & Nama Latin & Jumlah & Presentase \\
\hline Beringin & Ficus benjamina & 12 & $5,2 \%$ \\
Cemara Gembel & Cupressus papuana & 1 & $0,4 \%$ \\
Kenari & Canarium commuane & 207 & $90,0 \%$ \\
Mahoni & Swietenia mahogani & 9 & $3,9 \%$ \\
Petai Cina & Leucaena leucephala & 1 & $0,4 \%$ \\
\hline TOTAL & & $\mathbf{2 3 0}$ & $\mathbf{1 0 0 \%}$ \\
\hline
\end{tabular}




\section{Identifikasi pohon pada Jl. Jalak Harupat}

Presentase jumlah pohon pada Jl. Jalak Harupat didominasi oleh pohon 工 Mahoni (Swietenia mahogani) sebanyak 68\%, pohon lainnya adalah Falmboyan 을(Delonix regia) sebanyak 9\%; Kenari (Canarium commuane) sebanyak 5\%; ?. Beringin (Ficus benjamina) sebanyak 4\%; Angsana (Petrocarpus indicus) sebanyak 3\%; Ki hujan (Samanea saman) sebanyak 2\%; terakhir Glodogan bulat (Polyalthia fragrans), dan Kecrutan (Spatodhea campanulata) sebanyak 1\%. Data lebih lengkapnya ditampilkan pada Tabel 15 berikut ini. Karakter lanskap pada jalur hijau Jl. Jalak Harupat yang dibentuk dari dominasi pohon mahoni adalah evergreen atau selalu hijau, karena pohon mahoni pada iklim Kota Bogor adalah - tanaman yang hijau sepanjang tahun.

Tabel 15 Presentase jumlah pohon pada Jl. Jalak Harupat

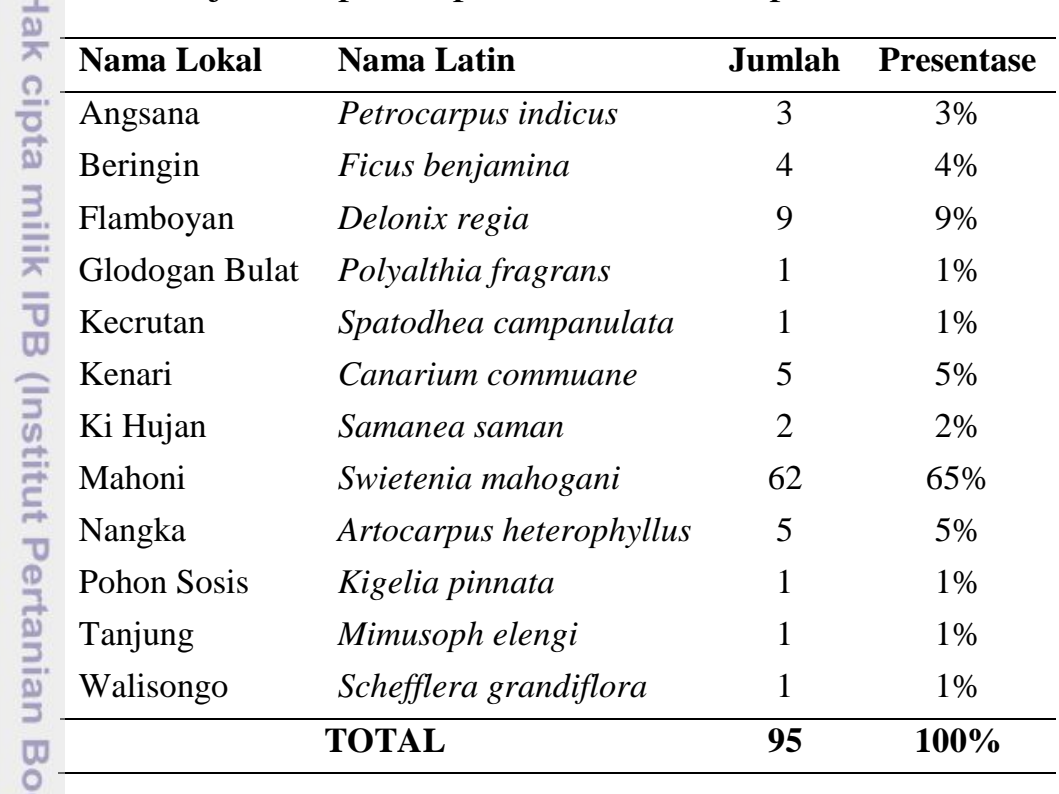

\section{Identifikâsi pohon pada Jl. Otto Iskandar Dinata}

Presentase jumlah pohon pada Jl. Otto Iskandar Dinata didominasi oleh pohon Angsana (Pterocarpus indicus) sebanyak 38\%, pohon lainnya adalah Bungur (Langerstromia speciosa) sebanyak 25\%; terakhir Bunga kupu-kupu (Bauhinia purpurea), Kenari (Canarium commuane), dan Kapuk randu (Ceiba pentandra) sebanyak 13\%. Data lebih lengkapnya ditampilkan pada Tabel 16 berikut ini.

Tabel 16 Presentase jumlah pohon pada Jl. Otto Iskandar Dinata

\begin{tabular}{llcc}
\hline Nama Lokal & Nama Latin & Jumlah & Presentase \\
\hline Angsana & Petrocarpus indicus & 3 & $38 \%$ \\
Bunga Kupu-Kupu & Bauhinia purpurea & 1 & $13 \%$ \\
Bungur & Langerstromia speciosa & 2 & $25 \%$ \\
Kenari & Canarium commuane & 1 & $13 \%$ \\
Kapuk Randu & Ceiba pentandra & 1 & $13 \%$ \\
\hline & TOTAL & $\mathbf{8}$ & $\mathbf{1 0 0 \%}$ \\
\hline
\end{tabular}


Karakter lanskap pada jalur hijau Jl. Otista yang dibentuk dari dominasi pohon angsana adalah evergreen atau selalu hijau, karena pohon angsana pada iklim Kota Bogor adalah tanaman yang hijau sepanjang tahun, dan diselingi warna keunguan ketika pohon bungur dan bunga kupu-kupu berbunga. Namun sayangnya ketika penelitian dilakukan banyak pohon yang ditebang akibat proyek pelebaran pedestrian dan pembangunan tepas 9 lawang sehingga mengurangi nilai estetis pada jalur hijau jalan.

\section{Identifikasi pohon pada Jl. Ir. H. Djuanda}

Presentase jumlah pohon pada Jl. Ir. H. Djuanda didominasi oleh pohon Kenari (Canarium communae) sebanyak 83\%, pohon lainnya adalah Mahoni (Swietenia mahogani) sebanyak 8\%; Angsana (Petrocarpus indicus) sebanyak $6 \%$ terakhir Beringin (Ficus benjamina), dan Dadap Merah (Erythirina cristagali) sebanyak 2\%. Data lebih lengkapnya ditampilkan pada Tabel 17 berikut ini. Karakter lanskap pada jalur hijau Jl. Djuanda yang dibentuk dari dominasi pohon Kenari adalah evergreen atau selalu hijau, karena pohon kenari pada: iklim Kota Bogor adalah tanaman yang hijau sepanjang tahun. Selain itu kanōpi yang terbentuk sudah cukup lebar sehingga jalur jalan terasa teduh.

Tabel 17 Presentase jumlah pohon pada Jl. Ir. H. Djuanda

\begin{tabular}{llcc}
\hline Nama Lokal & Nama Latin & Jumlah & Presentase \\
\hline Angsana & Petrocarpus indicus & 3 & $6 \%$ \\
Beringin & Ficus benjamina & 1 & $2 \%$ \\
Dadap Merah & Erythirina cristagali & 1 & $2 \%$ \\
Kenari & Canarium commuane & 43 & $83 \%$ \\
Mahoni & Swietenia mahogani & 4 & $8 \%$ \\
\hline \multicolumn{2}{r}{ TOTAL } & $\mathbf{5 2}$ & $\mathbf{1 0 0 \%}$ \\
\hline
\end{tabular}

Identifikasi pohon pada Jl. Raya Empang

Presentase jumlah pohon pada J1. Raya Empang didominasi oleh pohon Palem ekor tupai (Wodyetia bifurcata) sebanyak 42\%, pohon lainnya adalah Beringin (Ficus benjamina) sebanyak dan Kenari (Canarium commuane) sebanyak 12\%; Mangga (Mangifera indica), Nangka (Artocarpus heterophyllus), dan Pucuk merah (Sygygium oleiana) sebanyak 8\%; terakhir Ketapang (Terminalia catappa), Beringin karet (Ficus elastica), dan Sukun (Artocarpus communis) sebanyak 4\%. Data lebih lengkapnya ditampilkan pada Tabel 18 berikut ini. Karakter lanskap pada jalur hijau Jl. Raya Empang yang dibentuk dari dominasi pohon palem ekor tupai adalah sebagai pengarah, karena pohon palem ekor tupai yang ditanam berjajar pada jalur hijau jalan menegaskan arah pandang, namun karena tutupan kanopi pohon palem kecil sehingga terasa cukup terik jika melewati jalan ini. Selain itu terdapatnya satu pohon beringin karet besar di dekat alun-alun Raya Empang membuat kawasan sekitarnya teduh. Jl. Raya Empang pada dasarnya kurang memiliki jalur hijau jalan yang memadai karena minimnya lahan, sehingga jumlah pohon yang diobservasi hanya sedikit, oleh karena itu perlu penambahan jumlah pohon agar memadai fungsi penyerap polusi udara. 
Tabel 18 Presentase jumlah pohon pada Jl. Raya Empang

\begin{tabular}{llcc}
\hline Nama Lokal & Nama Latin & Jumlah & Presentase \\
\hline Beringin & Ficus benjamina & 3 & $12 \%$ \\
Beringin Karet & Ficus elastica & 1 & $4 \%$ \\
Kenari & Canarium commuane & 3 & $12 \%$ \\
Ketapang & Terminalia catappa & 1 & $4 \%$ \\
Mangga & Mangifera indica & 2 & $8 \%$ \\
Nangka & Artocarpus heterophyllus & 2 & $8 \%$ \\
Palem Ekor Tupai & Wodyetia bifurcata & 11 & $42 \%$ \\
Pucuk Merah & Sygygium oleiana & 2 & $8 \%$ \\
Sukun & Artocarpus communis & 1 & $4 \%$ \\
\hline
\end{tabular}

\section{Identifikăsi pohon pada Jl. Dadali}

Presentase jumlah pohon pada Jl. Dadali didominasi oleh pohon Kenari (Canarium communae) sebanyak 38\%, pohon lainnya adalah Angsana

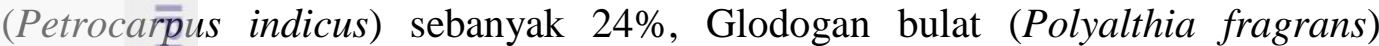
sebanyak 14\%; Flamboyan (Delonix regia) sebanyak 11\%; Mahoni (Swietenia mahogani) sebanyak 4\%, Beringin (Ficus benjamina), dan Kerai payung (Filicium decipiens) sebanyak 3\%; terakhir Pohon bunga kupu-kupu (Bauhinia purpurea $)$, Kersen (Muntingia calabura), Petai cina (Leucaena leucephala), dan Pinus (Piñus merkusii) sebanyak 1\%. Data lebih lengkapnya ditampilkan pada Tabel 19-Pohon yang paling mendominasi adalah kenari oleh karena itu karakter lanskap pada Jalan Dadali adalah evergreen/selalu hijau, namun tidak terasa membosankan karena banyak pedagang tanaman hias yang berjualan di Jalan ini memberikan berbagai warna dari tanaman hias yang dipajang. Hal ini memberikan dampak Regatif yaitu pedestrian jadi menyempit akibat pedagang tanaman hias menaruh qanaman displaynya di pedestrian sehingga sangat mengganggu para pejalan kaki yang akan melintas. Kanopi pohon di Jalan Dadali ini pada umumnya sudah lebar sehingga sangat nyaman dan teduh ketika melewati jalan ini.

Tabel 19 Presentase jumlah pohon pada Jl. Dadali

\begin{tabular}{llcc}
\hline Nama Lokal & Nama Latin & Jumlah & Presentase \\
\hline Angsana & Petrocarpus indicus & 19 & $24 \%$ \\
beringin & Ficus benjamina & 2 & $3 \%$ \\
Bunga kupu-kupu & Bauhinia purpurea & 1 & $1 \%$ \\
Flamboyan & Delonix regia & 9 & $11 \%$ \\
glodogan bulat & Polyalthia fragrans & 11 & $14 \%$ \\
Kenari & Canarium commuane & 30 & $38 \%$ \\
Kerai payung & Filicium decipiens & 2 & $3 \%$ \\
Kersen & Muntingia calabura & 1 & $1 \%$ \\
mahoni & Swietenia mahogani & 3 & $4 \%$ \\
Pete cina & Leucaena leucephala & 1 & $1 \%$ \\
Pinus & Pinus merkusii & 1 & $1 \%$ \\
\hline \multicolumn{4}{c}{} \\
\hline
\end{tabular}




\section{Identifikasi pohon pada Jl. Pemuda}

Presentase jumlah pohon pada Jl. Pemuda didominasi oleh pohon Kenari (Canarium commuane) sebanyak 61\%, pohon lainnya adalah Mahoni (Swietenia mahogani) sebanyak 24\%, Angsana (Petrocarpus indicus) sebanyak 7\%; Beringin (Ficus benjamina) sebanyak 4\%; Flamboyan (Delonix regia) sebanyak 2\%; terakhir Belimbing (Averrhoa carambola), dan Pinus (Pinus merkusii) sebanyak 1\%. Data lebih lengkapnya ditampilkan pada Tabel 20 berikut ini.

Pohon yang paling mendominasi adalah kenari oleh karena itu karakter lanskap pada Jalan Pemuda adalah evergreen/selalu hijau. Kanopi pohon di Jalan ini pada umumnya sudah lebar sehingga sangat nyaman dan teduh ketika melewati jalan ini, namun karena kondisi pohon yang sudah berusia tua sering terjadi patâhnya ranting-ranting pohon jika terjadi hujan lebat, oleh karena itu pemerintah membuat beberapa papan peringatan untuk tidak berteduh dibawah pohon apabila sedầng hujan.

Tabel 20 Presentase jumlah pohon pada Jl. Pemuda

\begin{tabular}{llcc}
\hline Nama Lokal & Nama Latin & Jumlah & Presentase \\
\hline Angsana & Petrocarpus indicus & 6 & $7 \%$ \\
Belimbing & Averrhoa carambola & 1 & $1 \%$ \\
Beringin & Ficus benjamina & 3 & $4 \%$ \\
Flamboyan & Delonix regia & 2 & $2 \%$ \\
Kenari & Canarium commuane & 51 & $61 \%$ \\
Bunga kupu-kupu & Bauhinia purpurea & 1 & $1 \%$ \\
Mahoni & Swietenia mahogani & 20 & $24 \%$ \\
\hline \multicolumn{5}{c}{} & $\mathbf{8 4}$ & $\mathbf{1 0 0 \%}$ \\
\hline
\end{tabular}

\section{Identifikasi pohon pada Jl. Raya Pajajaran}

Presentase jumlah pohon pada Jl. Raya Pajajaran didominasi oleh pohon Mahoni (Swietenia mahogani) sebanyak 78\%, pohon lainnya adalah Angsana (Petrocarpus indicus) sebanyak 10.4\%; Tanjung (Mimusoph elengi) sebanyak 2.5\%; Akasia (Acacia auriculiformis) sebanyak 1.3\%; Beringin (Ficus benjamina) sebanyak 1\%; Pohon bunga kupu-kupu (Bauhinia purpurea), Bintaro (Cerbera manghas), dan Flamboyan (Delonix regia) sebanyak 0.8\%; Ki Hujan (Samanea saman), dan Saga (Adenanthera pavonina) sebanyak 0.6\%; Kapuk randu (Ceiba pentandra) sebanyak 0.5\%; Dadap merah (Erythirina cristagali), Glodogan bulat (Polyalthia fragrans), Glodogan tiang (Polyalthia longifolia), Kenari (Canarium commuane), dan Ketapang (Terminalia catappa) sebanyak 0.4\%; terakhir Wali songo (Schefflera grandiflora) sebanyak $0.1 \%$. Data lebih lengkapnya ditampilkan pada Tabel 21 berikut ini.

Pohon yang paling mendominasi adalah mahoni oleh karena itu karakter lanskap pada Jalan pemuda adalah evergreen/selalu hijau. Jalan Raya Pajajaran ini merupakan satu-satunya jalan yang memiliki median jalan selebar $2 \mathrm{~m}$ yang ditanami pohon, semak, dan ground cover. Kanopi pohon di Jalan ini pada umumnya sudah lebar sehingga sangat nyaman dan teduh ketika melewati jalan ini, namun pada lokasi yang tidak terdapat median jalan yaitu dari kawasan 
pertigaan Pajajaran-Jalak Harupat sampai dengan kawasan Kampus IPB Gunung

Gede terasa lebih terik.

Tabel 21 Presentase jumlah pohon pada Jl. Raya Pajajaran

\begin{tabular}{|c|c|c|c|}
\hline Nama Lokal & Nama Latin & Jumlah & Presentase \\
\hline Akasia & Acacia auriculiformis & 10 & $1,3 \%$ \\
\hline Angsana & Petrocarpus indicus & 82 & $10,4 \%$ \\
\hline Beringin & Ficus benjamina & 8 & $1,0 \%$ \\
\hline Beringin Karet & Ficus elastica & 1 & $0,1 \%$ \\
\hline Bintaro & Cerbera manghas & 6 & $0,8 \%$ \\
\hline Bunga Kupu-Kupu & Bauhinia purpurea & 6 & $0,8 \%$ \\
\hline Dadap Merah & Erythirina cristagali & 3 & $0,4 \%$ \\
\hline Flamboyan & Delonix regia & 6 & $0,8 \%$ \\
\hline Glodogan Bulat & Polyalthia fragrans & 3 & $0,4 \%$ \\
\hline Glodogan Tiang & Polyalthia longifolia & 3 & $0,4 \%$ \\
\hline Kapuk Randu & Ceiba pentandra & 4 & $0,5 \%$ \\
\hline Kenari & Canarium commuane & 3 & $0,4 \%$ \\
\hline Ketapang & Terminalia catappa & 3 & $0,4 \%$ \\
\hline Ki Hujan & Samanea saman & 5 & $0,6 \%$ \\
\hline Mahoni & Swietenia mahogani & 618 & $78,3 \%$ \\
\hline Pohon Sosis & Kigelia pinnata & 2 & $0,3 \%$ \\
\hline Saga & Adenanthera pavonina & 5 & $0,6 \%$ \\
\hline Tanjung & Mimusoph elengi & 20 & $2,5 \%$ \\
\hline Wali Songo & Schefflera grandiflora & 1 & $0,1 \%$ \\
\hline \multicolumn{2}{|c|}{ TOTAL } & 789 & $100.0 \%$ \\
\hline
\end{tabular}

Jūmlah yang banyak dan jenis vegetasi yang beragam pada 10 jalan penelitiam sudah dalam kategori baik dilihat dari berbagai fungsinya sebagai tanaman pengarah, peneduh, dan pereduksi polusi udara, namun efektifitasnya perlu ditingkatkan dengan cara menambahkan vegetasi yang sesuai dalam menurunkan konsentrasi polutan udara.

\section{Identifikasi Luas Penutupan Kawasan Awal}

Luas kawasan penelitian dapat diketahui dari hasil analisa CITYgreen, pada luasan awal berdasarkan Tabel 22, dapat diketahui bahwa luas wilayah jalan yang terbesar yaitu Jalan Raya Pajajaran sebesar $0,553 \mathrm{~km}^{2}$, sedangkan luas terkecil yaitu Jalan Raya Empang sebesar $0,014 \mathrm{~km}^{2}$. Total luas jalan sampel penelitian adalah $0,9859 \mathrm{~km}^{2}$, dengan rata-rata luas jalan $0,0986 \mathrm{~km}^{2}$. Luas perkerasan jalan (impervious area) sangat mempengaruhi tingkat serapan polusi udara karena semakin besar jalan, maka akan meningkatkan kapasitas kendaraan yang dapat melewati jalan tersebut sehingga meningkatnya konsentrasi polutan di udara akibat gas buang kendaraan bermotor. Jalan Raya Pajajaran sebagai jalan terluas męrupakan penyumbang polusi terbesar di Kota Bogor sehingga perlu adanya penataan vegetasi untuk mengurangi dampak pencemaran udara dari gas buang kendaraan bermotor. 
Luas penutupan kawasan berdasarkan Tabel 22 terdiri dari 3 kategori penutupan lahan berdasarkan kategori CITYgreen Feature yaitu pohon (Trees), jalan (Impervieus), dan perkotaan (Urban). Total penutupan lahan pohon pada 10 sampel jalan penelitian adalah $0,9859 \mathrm{~km}^{2}$ dengan komposisi penutupan vegetasi $0,1958 \mathrm{~km}^{2}$, penutupan perkerasan jalan adalah $0.4839 \mathrm{~km}^{2}$, dan penutupan kawasan urban adalah $0,3815 \mathrm{~km}^{2}$. Komposisi penutupan pohon sangat berpotensi untuk meningkatkan jumlah jerapan polusi. Semakin besar luas penutupan pohon maka akan meningkatkan konsentrasi jerap polusi itu sendiri. Idealnya 30\% dari total area merupakan luas RTH, namun jika dilihat dari komposisinya luas tutupan pohon hanya $19,86 \%$ dari keseluruhan total area oleh karena itu perlu ada peningkatan luas penutupan pohon melalui penambahan jumlah vegetasi pada 10 jalan sampel penelitian.

Tabel 22 Tabel komposisi luas penutupan kawasan penelitian

\begin{tabular}{lcccc}
\hline \multirow{2}{*}{ Nama Jalan } & \multicolumn{4}{c}{ Komposisi Penutupan Lahan (km2) } \\
\cline { 2 - 5 } & Total area & Pohon & Perkerasan & Perkotaan \\
\hline JL. Raya Pajajaran & 0,5528 & 0,0633 & 0,2874 & 0,2047 \\
JL. Dadali & 0,0465 & 0,0134 & 0,0178 & 0,0218 \\
JL. Raya Empang & 0,0143 & 0,0022 & 0,0067 & 0,0060 \\
JL. Jalak Harupat & 0,0327 & 0,0159 & 0,0163 & 0,0091 \\
JL. Jendral Ahmad Yani & 0,1002 & 0,0396 & 0,0452 & 0,0434 \\
JL. Ir. H. Djuanda & 0,0628 & 0,0097 & 0,0369 & 0,0217 \\
JL. Otto Iskandar Dinata & 0,0209 & 0,0043 & 0,0127 & 0,0062 \\
JL. Pemuda & 0,0560 & 0,0240 & 0,0225 & 0,0212 \\
JL. R. E. Martadinata & 0,0443 & 0,0102 & 0,0158 & 0,0240 \\
JL. Jendral Sudirman & 0,0555 & 0,0133 & 0,0225 & 0,0235 \\
\hline \multicolumn{1}{c}{ Total } & $\mathbf{0 , 9 8 5 9}$ & $\mathbf{0 , 1 9 5 8}$ & $\mathbf{0 , 4 8 3 9}$ & $\mathbf{0 , 3 8 1 5}$ \\
\hline \multicolumn{4}{c}{}
\end{tabular}

\section{Analisis Kualitas Udara}

Hasil analisis kualitas udara yang diperoleh dari CITYgreen kemudian diolah menggunakan metode statistika regresi linier sederhana, dapat diketahui bahwa hubungan antara kebutuhan total area pohon berkorelasi positif dengan jumlah polutan $\mathrm{O}_{3}, \mathrm{NO}_{2}, \mathrm{SO}_{2}, \mathrm{PM} 10$, dan $\mathrm{CO}$ dengan nilai $\mathrm{R}^{2}=0,99$ hal ini menandakan bahwa jumlah polutan yang terserap sebanding dengan total area pohon sebesar 99\%. Hal ini membuktikan bahwa semakin besar luas tutupan pohon maka akan semakin besar konsentrasi serapan polusi yang didapatkan. Peningkatan luas penutupan kanopi pohon dapat dilakukan dengan cara penambahan jumlah pohon yang ditanam pada jalur hijau jalan karena luas kanopi yang hanya $19,86 \%$ saja dari total luas kawasan penelitian. 


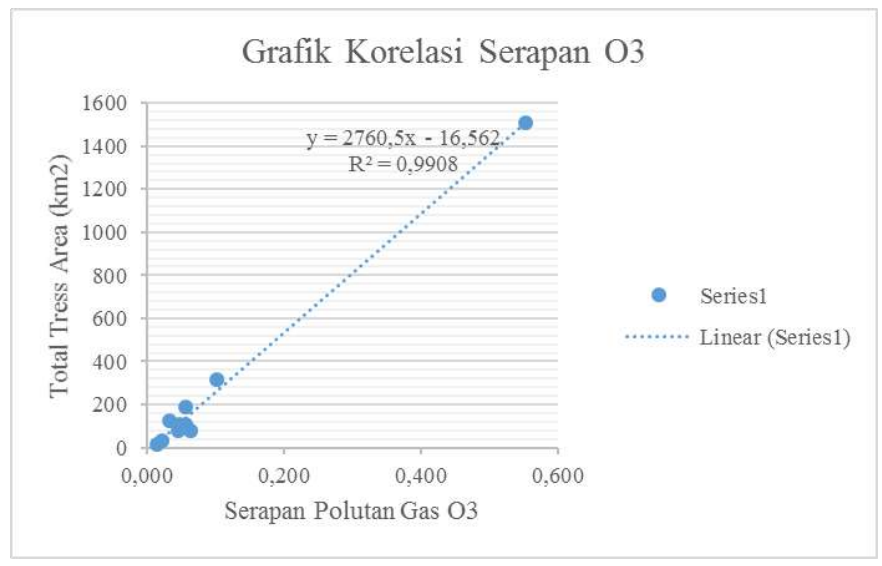

Gambar 30 Grafik Korelasi $\mathrm{O}_{3}$

Persamaan linear sederhana antara variabel total area pohon $\left(\mathrm{km}^{2}\right)$ dengan jumlah serapan polutan gas $\mathrm{O}_{3}$ (Lbs) adalah $\hat{\mathrm{Y}}=2.760,5 \mathrm{x}-16,562 \mathrm{Hal}$ ini menunjukan bahwa $\hat{Y}$ adalah penduga variable terikat dinama nilai $2.760,5$ adalah koefisien $\overline{\underline{x}}$ dan 16,562 adalah koefisien y yang merupakan slop/ kemiringan garis regresi. Berdasarkan Gambar 30 dapat diketahui nilai $\mathrm{R}^{2}=0,9908$ ini membuktikan bahwa hubungan kebutuhan total area pohon dengan jumlah serapan polutan $\mathrm{O}_{3}$ berkorelasi positif, yaitu semakin besar luas tutupan pohon maka akañ semakin besar konsentrasi serapan polusi yang didapatkan, dan jumlah polutan yầng terserap sebanding dengan total area pohon sebesar $99 \%$.

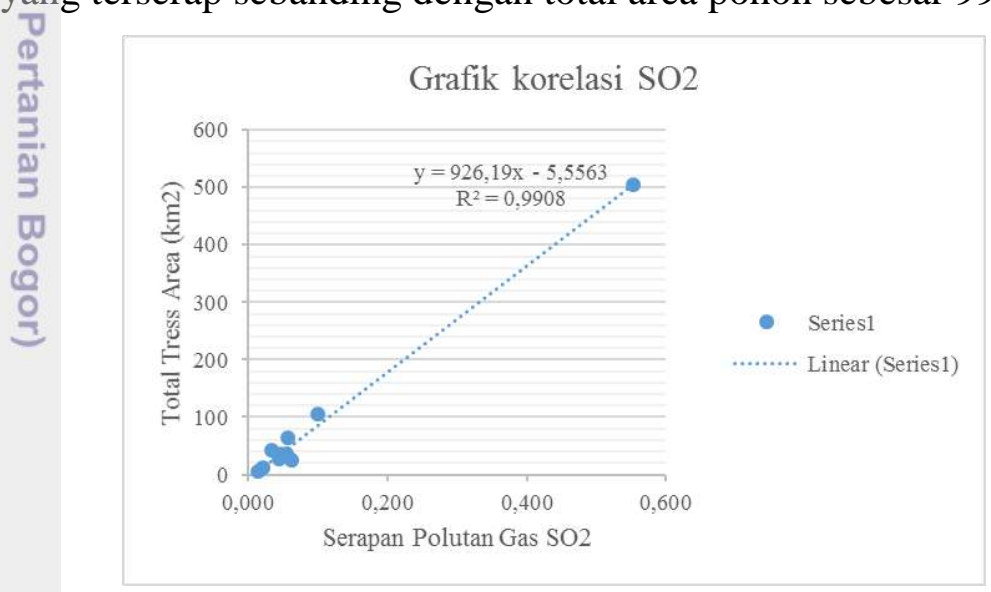

Gambar 31 Grafik Korelasi $\mathrm{SO}_{2}$

Persamaan linear sederhana antara variabel total area pohon $\left(\mathrm{km}^{2}\right)$ dengan jumlah serapan polutan gas $\mathrm{SO}_{2}$ (Lbs) adalah $\hat{\mathrm{Y}}=926,19 \mathrm{x}-5,5563 \mathrm{Hal}$ ini menunjukan bahwa $\hat{Y}$ adalah penduga variable terikat dimana nilai 926,19 adalah koefisien $\mathrm{x}$ dan 5,5563 adalah koefisien y yang merupakan slop/ kemiringan garis regresi. Berdasarkan Gambar 31 dapat diketahui nilai $R^{2}=0,9908$ ini membuktikan bahwa hubungan kebutuhan total area pohon dengan jumlah serapan polutan $\mathrm{SO}_{2}$ berkorelasi positif, yaitu semakin besar luas tutupan pohon maka akan semakin besar konsentrasi serapan polusi yang didapatkan, dan jumlah polutan yang terserap sebanding dengan total area pohon sebesar 99\%. 


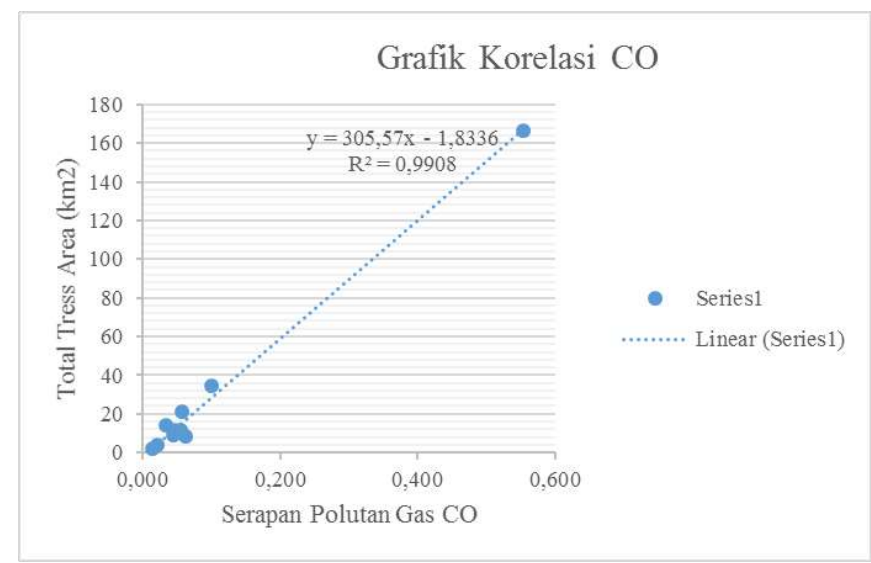

Gambar 32 Grafik Korelasi Polutan CO

Persamaan linear sederhana antara variabel total area pohon $\left(\mathrm{km}^{2}\right)$ dengan juntah serapan polutan gas CO (Lbs) adalah $\hat{\mathrm{Y}}=305,57 \mathrm{x}-1,8336 \mathrm{Hal}$ ini menunjukan bahwa $\hat{Y}$ adalah penduga variable terikat dimana nilai 305,57 adalah koefisien $\mathrm{x}$ dan 1,8336 adalah koefisien y yang merupakan slop/ kemiringan garis rege meñbuktikan bahwa hubungan kebutuhan total area pohon dengan jumlah serapan polutan CO berkorelasi positif, yaitu semakin besar luas tutupan pohon maka akan semakin besar konsentrasi serapan polusi yang didapatkan, dan jumlah polâtan yang terserap sebanding dengan total area pohon sebesar $99 \%$.

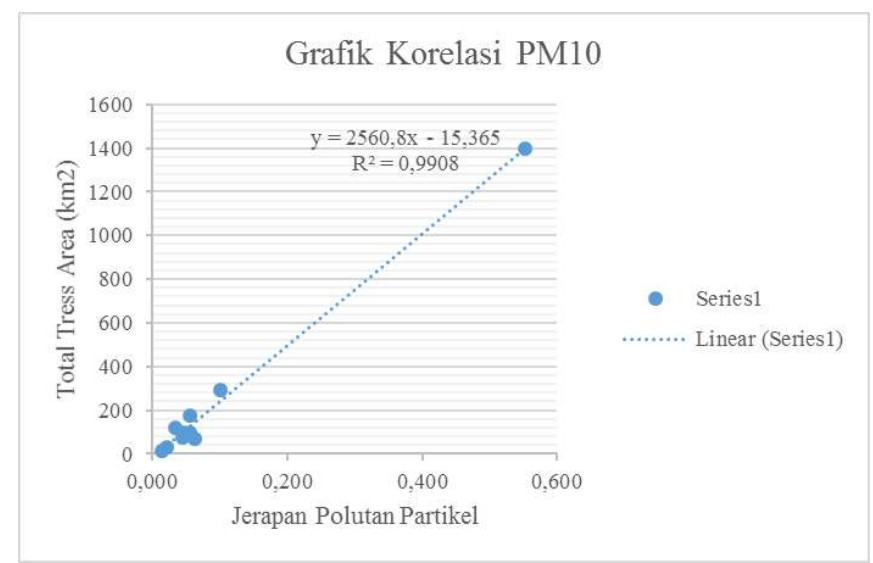

Gambar 33 Grafik Korelasi Polutan Partikel (PM10)

Persamaan linear sederhana antara variabel total area pohon $\left(\mathrm{km}^{2}\right)$ dengan jumlah serapan polutan partikel PM10 (Lbs) adalah $\hat{Y}=2.560,8 \mathrm{x}-15,365 \mathrm{Hal}$ ini menunjukan bahwa $\hat{Y}$ adalah penduga variable terikat dimana nilai $2.560,8$ adalah koefisien $\mathrm{x}$ dan 15,365 adalah koefisien y yang merupakan slop/ kemiringan garis regresi. Berdasarkan Gambar 33 dapat diketahui nilai $R^{2}=0,9908$ ini membuktikan bahwa hubungan kebutuhan total area pohon dengan jumlah serapan polutan CO berkorelasi positif, yaitu semakin besar luas tutupan pohon maka akan semakin besar konsentrasi serapan polusi yang didapatkan, dan jumlah polutan yang terserap sebanding dengan total area pohon sebesar $99 \%$. 


\section{Kapasitas Cadangan Karbon}

Kapasitas cadangan karbon yang diestimasi dari penutupan kawasan I penelitian menggunakan pemodelan CITYgreen, berdasarkan rekapitulasi - CITYgreen analisis dapat diketahui bahwa kapasitas cadangan karbon yang ? diperoleh Kota Bogor pada 10 ruas jalan sampel penelitian adalah 1.029,34 ton E dengan kenaikan tiap tahunnya sekitar 8.011 ton/tahun. Kapasitas cadangan 즐 karbon terbesar terdapat pada Jl. Jendral Ahmad Yani sebesar 421,17 ton, sedangkan yang terendah adalah Jl. Raya Empang sebesar 0,23 ton/tahun untuk lebih lengkapnya disajikan dalam Tabel 23 berikut ini.

Jalan Jendral Ahmad Yani memiliki jumlah kapasitas karbon yang paling besar akibat kanopi pohon yang sangat padat dan besar pada jalur hijau jalannya (Nowak et.all. 2013), sehingga nilai cadangan karbonnya besar, sedangakn Jalan Raya Empang merupakan jalan yang jarang terdapat pohon, oleh karena itu nilai $\sqsubset$ cadangan $\_$karbonnya paling rendah. Perlunya penambahan jumlah pohon untuk meningkatkan cadangan karbon karena semakin besar luas tutupan kanopi pohon pada suatu jalan akan meningkatkan kapasitas cadangan karbon yang dapat diperoleh tiap tahunnya.

Tabel 23 Manfaat cadangan karbon

\begin{tabular}{|c|c|c|}
\hline \multirow{2}{*}{$\begin{array}{l}\text { 忈Nama Jalan } \\
\text { un } \\
\text { : }\end{array}$} & \multicolumn{2}{|c|}{ Manfaat Cadangan Karbon } \\
\hline & $\begin{array}{c}\text { Kapasitas Penyimpanan } \\
\text { Karbon (ton) }\end{array}$ & $\begin{array}{c}\text { Kenaikan per Tahun } \\
\text { (ton/year) }\end{array}$ \\
\hline JL. Pad̃jajaran & 20,21 & 0,16 \\
\hline JL. Dactali & 142,08 & 1,11 \\
\hline JL. Raỹa Empang & 0,23 & 0,001 \\
\hline JL. JaFak Harupat & 1,69 & 0,01 \\
\hline JL. Jeñdral Ahmad Yani & 421,17 & 3,28 \\
\hline JL. Ir.dH. Djuanda & 1,03 & 0,01 \\
\hline JL. Otto Iskandar Dinata & 45,58 & 0,35 \\
\hline JL. Pemuda & 254,84 & 1,98 \\
\hline JL. R. E. Martadinata & 1,08 & 0,01 \\
\hline JL. Jendral Sudirman & 141,43 & 1,1 \\
\hline Total & 1029,34 & 8,011 \\
\hline
\end{tabular}

\section{Nilai Pengurangan Polusi Udara}

Berdasarkan hasil analisa dengan menggunakan perangkat lunak CITYgreen zat pencemar yang dapat diserap oleh pohon pada jalur hijau jalan di 10 jalan sampel penelitian adalah $\mathrm{O}_{3}$ sebesar 2.256,04 Lbs/tahun atau setara dengan $1.034,4 \mathrm{~kg}(1 \mathrm{lbs}=0.40469 \mathrm{~kg}), \mathrm{SO}_{2}$ sebesar $857,6 \mathrm{Lbs} /$ tahun atau setara dengan $347,06 \mathrm{~kg}, \mathrm{NO}_{2}$ sebesar 1.312,84 Lbs/tahun atau setara dengan 535,74 kg, PM10 sebesar 2.371,11 Lbs/tahun atau setara dengan 959,56 kg, dan CO sebesar $282,94 \mathrm{Es} /$ tahun atau setara dengan $114,5 \mathrm{~kg}$, dimana polutan terberat yang bisa diserap adalah $\mathrm{O}_{3}$, dan konsentrasi polutan terendah yang dapat diserap adalah $\mathrm{CO}$, oleh karena itu untuk lebih meningkatkan masa polutan yang dapat diserap diperlukanlah penambahan vegetasi yang sesuai dengan kriteria pohon penyerap partikel pęlutan. 


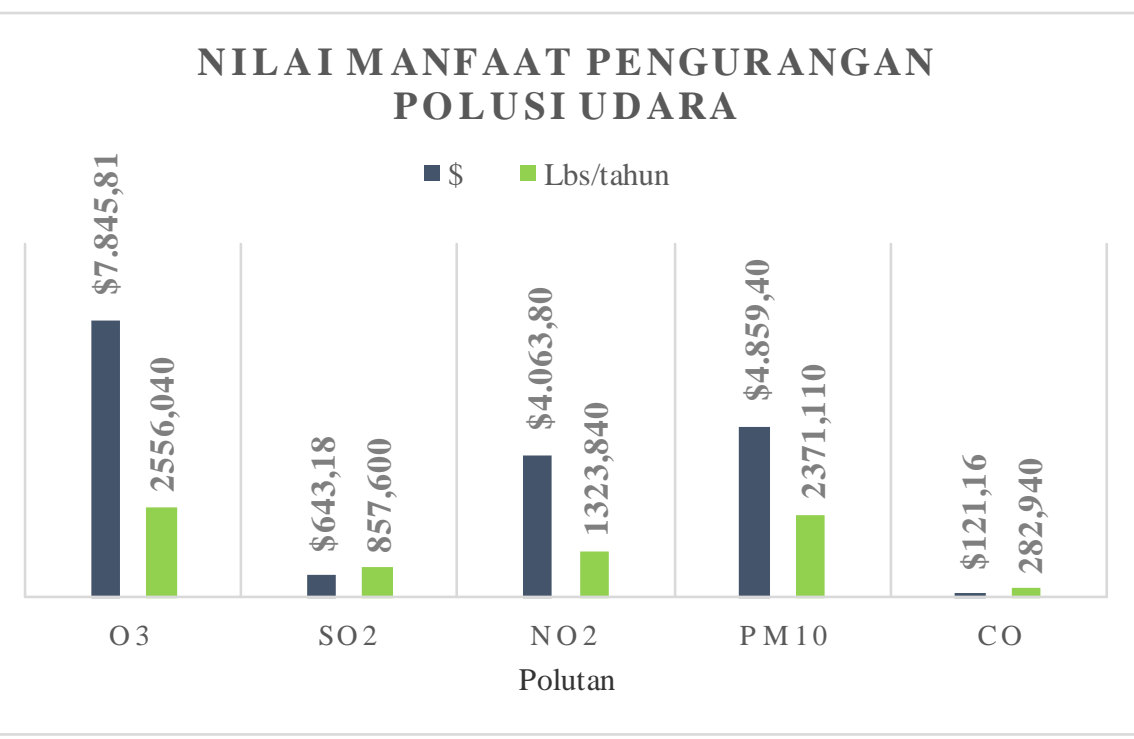

Gảambar 34 Diagram manfaat pengurangan polusi udara dan manfaat ekonomi 플

Nilẩ manfaat ekonomi merupakan nilai yang harus dikeluarkan oleh pemerintah dalam menanggulangi masalah kerusakan lingkungan dalam hal ini adalah penêemaran oleh polutan di udara. Nilai manfaat ekonomi yang dapat dihemat padâ. 10 sampel jalan penelitian adalah $\mathrm{O}_{3}$ sebesar \$ 7.845,81 atau setara dengan $\mathrm{Rp}$ 04.608.184,73 (1\$ = Rp 13.333), $\mathrm{SO}_{2}$ sebesar \$ 643,18 atau setara dengan $\mathrm{Rp}$ 8.575.518,94 $\mathrm{NO}_{2}$ sebesar \$ 4.063,80 atau setara dengan Rp 54.182.645,40, PM10 sebesar \$ 4.859,40 atau setara dengan Rp 64.790.380,20 dan CO sebesar \$ 121,16 ataษึ setara dengan $\mathrm{Rp} 1.615 .426,28$ dimana biaya penghematan terbesar yaitu $\mathrm{O}_{3}$, dan biaya terendah adalah CO. Data nilai manfaat pengurangan polusi udara yang lebih lengkap disajikan pada Gambar 34.

\section{Pohon Penyerap Polusi Udara dalam Bentuk Gas}

Hasil analisa dengan menggunakan metode skoring terhadap pohon yang sesuai karena memiliki kemampuan menyerap polutan gas $\left(\mathrm{O}_{3}, \mathrm{NO}_{2}, \mathrm{SO}_{2}\right.$, dan $\mathrm{CO})$ dalam udara yang baik dengan ciri fisik pohon bertajuk padat, memiliki lapisan vegetasi (ground cover, semak, perdu, dan pohon), berdaun tipis, memiliki jumlah daun banyak, dan jarak tanam rapat. Pohon yang memiliki nilai skor di atas $80 \%$ yaitu pohon yang termasuk dalam kriteria sangat sesuai adalah pohon Kenari (Canarium commuane), Mahoni (Swietenia mahogani), Bunga kupu-kupu (Bauhinia purpurea), dan Bungur (Langerstromia speciosa) untuk lebih lengkapnya disajikan dalam Tabel 24. Pohon yang termasuk dalam kategori sesuai harus ditambahkan, dan pohon yang termasuk dalam kriteria tidak sesuai sebaiknya dikurangi. 
Tabel 24 Daftar presentase kesesuaian pohon penyerap polusi gas

\begin{tabular}{|c|c|c|c|}
\hline Nama lokal & Nama latin & Presentase & Kesesuaian \\
\hline Kenari & Canarium commuane & $93 \%$ & Sangat sesuai \\
\hline Mahoni & Swietenia mahogani & $93 \%$ & Sangat sesuai \\
\hline Bunga kupu-kupu & Bauhinia purpurea & $90 \%$ & Sangat sesuai \\
\hline Bungur & Langerstromia speciosa & $87 \%$ & Sangat sesuai \\
\hline Flamboyan & Delonix regia & $80 \%$ & Sesuai \\
\hline Glodogan bulat & Polyalthia fragrans & $80 \%$ & Sesuai \\
\hline Glogogan tiang & Polyalthia longifolia & $80 \%$ & Sesuai \\
\hline Ki hujăăn & Samanea saman & $80 \%$ & Sesuai \\
\hline Kerai payung & Filicium decipiens & $77 \%$ & Sesuai \\
\hline Saga of & Adenanthera pavonina & $77 \%$ & Sesuai \\
\hline Cema䇥 gembel & Cupressus papuana & $73 \%$ & Sesuai \\
\hline Jamb塎Air & Syzygium samarangense & $73 \%$ & Sesuai \\
\hline Tanjuñg & Mimusoph elengi & $73 \%$ & Sesuai \\
\hline Angsana & Petrocarpus indicus & $70 \%$ & Sesuai \\
\hline Beringुำ & Ficus benjamina & $70 \%$ & Sesuai \\
\hline Kersen & Muntingia calabura & $70 \%$ & Sesuai \\
\hline Ketapang & Terminalia catappa & $70 \%$ & Sesuai \\
\hline Pucukmerah & Sygygium oleiana & $70 \%$ & Sesuai \\
\hline Wali songo & Schefflera grandiflora & $70 \%$ & Sesuai \\
\hline Bintare & Cerbera manghas & $67 \%$ & Sesuai \\
\hline Biola Cantik & Ficus lyrata & $67 \%$ & Sesuai \\
\hline Kecrutan & Spatodhea campanulata & $67 \%$ & Sesuai \\
\hline Pete cina & Leucaena leucephala & $67 \%$ & Sesuai \\
\hline Beringin karet & Ficus elastica & $63 \%$ & Sesuai \\
\hline Pohon sosis & Kigelia pinnata & $63 \%$ & Sesuai \\
\hline Waru & Hibiscus tiliaceus & $63 \%$ & Sesuai \\
\hline Akasia & Acacia auriculiformis & $60 \%$ & Kurang sesuai \\
\hline Dadap merah & Erythirina cristagali & $60 \%$ & Kurang sesuai \\
\hline Nangka & Artocarpus heterophyllus & $60 \%$ & Kurang sesuai \\
\hline Pinus & Pinus merkusii & $60 \%$ & Kurang sesuai \\
\hline Durian & Durio zibethinus & $57 \%$ & Kurang sesuai \\
\hline Mangga & Mangifera indica & $57 \%$ & Kurang sesuai \\
\hline Palemekor tupai & Wodyetia bifurcata & $57 \%$ & Kurang sesuai \\
\hline Belimbing & Averrhoa carambola & $50 \%$ & Kurang sesuai \\
\hline Sukun & Artocarpus communis & $50 \%$ & Kurang sesuai \\
\hline Kapukrandu & Ceiba pentandra & $47 \%$ & Kurang sesuai \\
\hline
\end{tabular}




\section{Pohon Penyerap Polusi Udara dalam Bentuk Partikel}

Berdasarkan skoring yang telah dilakukan, secara umum diperoleh hasil pohon yang termasuk kriteria sangat sesuai karena memiliki kemampuan menyerap polutan partikel (PM10) dalam udara yang baik, yaitu dengan skor diatas $80 \%$ adalah Kenari (Canarium commuane), Cemara gembel (Cupressus papuana), Bunga kupu-kupu (Bauhinia purpurea), Mahoni (Swietenia mahogani), dan Pinus (Pinus merkusii) dimana semua pohon ini sangat sesuai dengan kriteria fisik pohon penyerap polusi gas yaitu memiliki ciri fisik struktur permukaan daun bertepi kasar, berlekuk, berbulu/bertrikoma, memiliki daun jarum/ daun lebar, memiliki tajuk padat, memiliki tekstur kulit batang dan ranting kasar, ranting berduri, dan ranting yang padat, untuk lebih lengkapnya disajikan dalam Tabel 25. Pohøn yang termasuk dalam kategori sesuai harus ditambahkan, dan pohon yang termasuk dalam kriteria kurang sesuai sebaiknya dikurangi.

Tabel 25 Daftar presentase kesesuaian pohon penyerap polusi partikel

\begin{tabular}{llcl}
\hline Nama lokal & \multicolumn{1}{c}{ Nama latin } & Presentase & Kesesuaian \\
\hline Kenari & Canarium commuane & $89 \%$ & Sangat sesuai \\
\hline Eemara gembel & Cupressus papuana & $89 \%$ & Sangat sesuai \\
\hline Bunga kupu-kupu & Bauhinia purpurea & $82 \%$ & Sangat sesuai \\
\hline Mahoni & Swietenia mahogani & $82 \%$ & Sangat sesuai \\
\hline Pinus & Pinus merkusii & $82 \%$ & Sangat sesuai \\
\hline Bungur & Langerstromia speciosa & $79 \%$ & Sesuai \\
\hline Glodogan bulat & Polyalthia fragrans & $76 \%$ & Sesuai \\
\hline Beringin karet & Ficus elastica & $74 \%$ & Sesuai \\
\hline Biola cantik & Ficus lyrata & $74 \%$ & Sesuai \\
\hline Glogogan tiang & Polyalthia longifolia & $74 \%$ & Sesuai \\
\hline Kerai payung & Filicium decipiens & $74 \%$ & Sesuai \\
\hline Beringin & Ficus benjamina & $71 \%$ & Sesuai \\
\hline Kersen & Muntingia calabura & $71 \%$ & Sesuai \\
\hline Ki hujan & Samanea saman & $71 \%$ & Sesuai \\
\hline Bintaro & Cerbera manghas & $68 \%$ & Sesuai \\
\hline Jambu Air & Syzygium samarangense & $68 \%$ & Sesuai \\
\hline pucuk merah & Sygygium oleiana & $68 \%$ & Sesuai \\
\hline Tanjung & Mimusoph elengi & $68 \%$ & Sesuai \\
\hline Wali songo & Schefflera grandiflora & $68 \%$ & Sesuai \\
\hline Angsana & Petrocarpus indicus & $66 \%$ & Sesuai \\
\hline Flam boyan & Delonix regia & $66 \%$ & Sesuai \\
\hline Kecrutan & Spatodhea campanulata & $66 \%$ & Sesuai \\
\hline Nangka & Artocarpus heterophyllus & $66 \%$ & Sesuai \\
\hline Saga & Adenanthera pavonina & $66 \%$ & Sesuai \\
\hline Waru & Hibiscus tiliaceus & $66 \%$ & Sesuai \\
\hline Dadap merah & Erythirina cristagali & $63 \%$ & Sesuai \\
\hline Ketapang & Terminalia catappa & $63 \%$ & Sesuai \\
\hline & & & \\
\hline
\end{tabular}




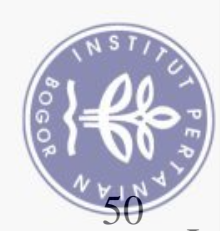

Lanjutan Tabel 25 Daftar presentase kesesuaian pohon penyerap polusi

\begin{tabular}{llll}
\hline Durian & Durio zibethinus & $61 \%$ & Sesuai \\
\hline Sukun & Artocarpus communis & $58 \%$ & Kurang sesuai \\
\hline Belimbing & Averrhoa carambola & $55 \%$ & Kurang sesuai \\
\hline Mangga & Mangifera indica & $55 \%$ & Kurang sesuai \\
\hline Pete cina & Leucaena leucephala & $55 \%$ & Kurang sesuai \\
\hline Akasia & Acacia auriculiformis & $53 \%$ & Kurang sesuai \\
\hline Pohon sosis & Kigelia pinnata & $53 \%$ & Kurang sesuai \\
\hline Kapuk randu & Ceiba pentandra & $47 \%$ & Kurang sesuai \\
\hline Palem ekor tupai & Wodyetia bifurcata & $45 \%$ & Kurang sesuai \\
\hline
\end{tabular}

\section{Rekomendasi}

Rēkomendasi penambahan pohon yang bisa ditanam pada 10 sampel jalan penelitianuntuk meningkatkan efektifitas penyerapan polusi udara berjumlah 505 pohon, dêngan deskripsi pohon yang direkomendasikan tersaji secara lengkap dalam tabel 26 berikut ini, dan lokasi penanaman yang sesuai dapat dilihat dalam Lampiran 3 sampai dengan Lampiran 24.

Tabel $26 \overline{\mathrm{R}}$ ekomendasi tanaman pada 10 jalan sampel penelitian

\begin{tabular}{|c|c|c|}
\hline No & Nama Lokal & Nama Latin \\
\hline 1. & 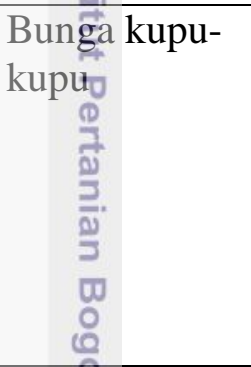 & $\begin{array}{l}\text { Bauhinia } \\
\text { purpurea }\end{array}$ \\
\hline 2. & Bungur & $\begin{array}{l}\text { Langerstromia } \\
\text { speciosa }\end{array}$ \\
\hline
\end{tabular}

Pohon bunga kupu-kupu merupakan pohon yang sangat sesuai dalam mereduksi polusi udara baik dalam bentuk gas maupun dalam bentuk partikel, selain itu pohon ini mudah perawatannya dan relatif tidak banyak hama yang menyerang, selain itu pohon ini juga dapat memperkuat karakter jalan terutama JL. RE Martadinata yang merupakan jalan dengan dominasi pohon berbunga ungu dan pink.

Pohon Bungur memiliki bunga berwarna pink keunguan sehingga bisa memperkuat karakter tapak jika ditanam di jalur hijau jalan pada kawasan penelitian. Pohon bungur juga bermanfaat dalam mereduski polusi udara dalam bentuk gas dibuktikan dengan nilai presentase penyerapan polutan gas $>80 \%$, selain itu pohon ini memiliki daun yang cukup lebar dan periode gugur daun yang relatif jarang (Evergreen) sehingga tidak terlalu mengotori kawasan.

\begin{tabular}{lll}
\hline 3. Cemara gembel & $\begin{array}{l}\text { Cupressus } \\
\text { papuana }\end{array}$ & $\begin{array}{l}\text { Pohon cemara gembel merupakan pohon yang } \\
\text { baik dalam mereduksi polusi dalam bentuk } \\
\text { partikel debu, karena bentuk daun jarum dan } \\
\text { tekstur kulit batang pohon yang kasar, selain }\end{array}$ \\
& & $\begin{array}{l}\text { itu pohon ini memiliki karakter tajuk yang } \\
\text { berbentuk kerucut menambah nilai estetika jika } \\
\text { ditanam pada jalur hijau jalan tapak penelitian. }\end{array}$ \\
& $\begin{array}{l}\text { Pohon ini juga merupakan pohon yang mudah } \\
\text { dalam perawatannya karena daunnya jarang } \\
\text { berguguran (Evergreen). }\end{array}$ \\
\hline 4. Kenari & Canarium & Pohon kenari merupakan pohon yang sangat \\
\hline
\end{tabular}




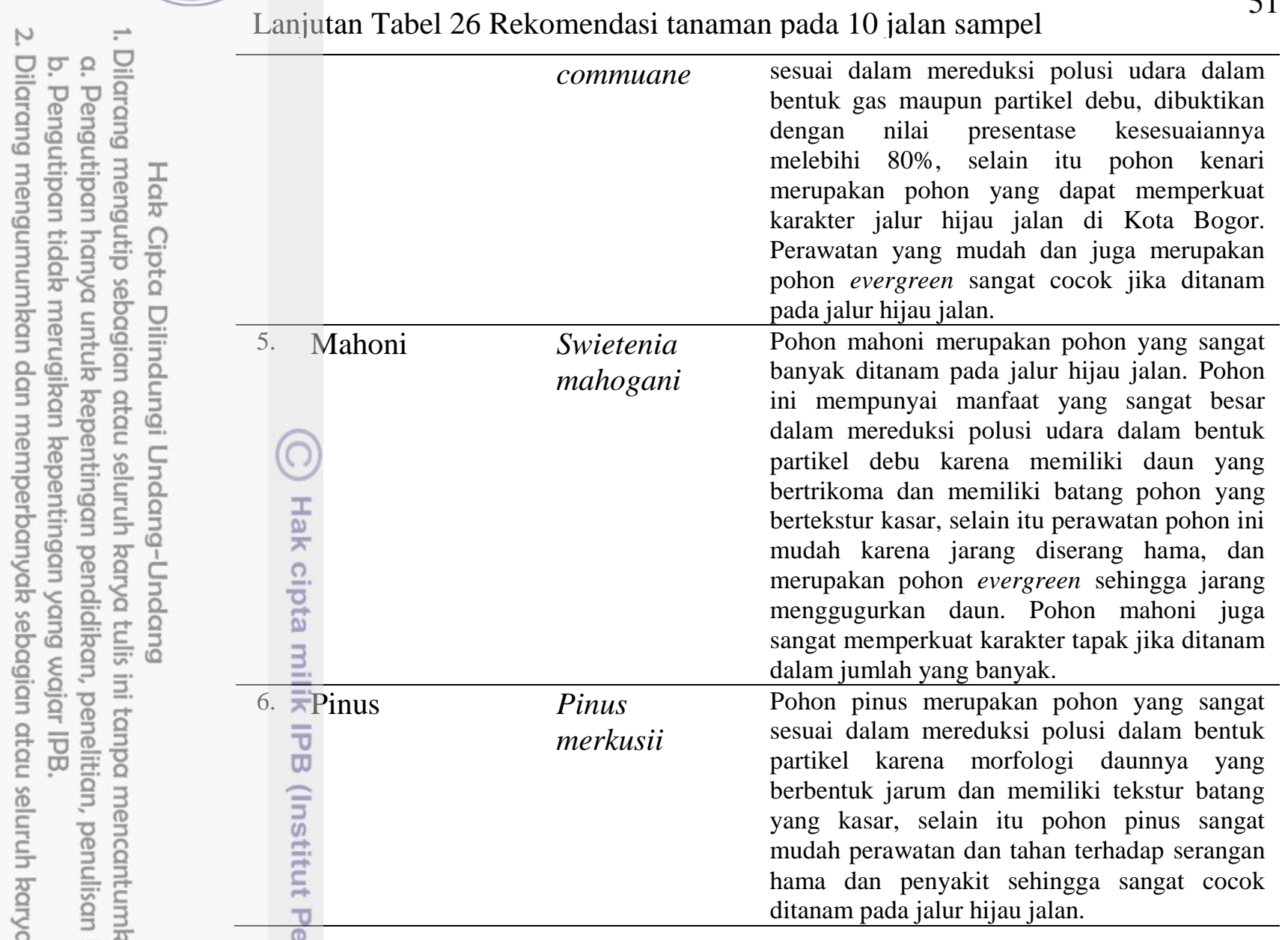

Pohon yang ditambahkan bisa pada 10 lokasi penelitian berjumlah 505 pohôn. Penambahan pohon ini dapat dilakukan jika tersedia tempat/lahan yang masih kosong pada jalur hijau jalan, dan diletakan pada jalan yang memang sudah memiliki jenis pohon yang menjadi pohon rekomendasi (menambahkan pohon yang sudah ada) dengan rincian tersaji pada Lampiran 11.

\section{Hasil Analisa Setelah Penambahan Vegetasi Rekomendasi}

Hasil rekomendasi pohon yang sesuai ditanam pada jalur hijau jalan kawasan penelitian kemudian diinputkan kembali pada CITYgreen sehingga menghasilkan nilai jasa lingkungan setelah penambahan pohon di setiap jalur hijau jalan dikawasan penelitian, rekapitulasi analisa CITYgreen nya adalah sebagai berikut:

1. Analisa Komposis Luas Penutupan Lahan

Penambahan vegetasi rekomendasi akan meningkatkan luas penutupan terutama tutupan vegetasi, setelah dilakukan penambahan pohon maka total luas pohon pađa jalur hijau jalan adalah $0,036 \mathrm{~km}^{2}$ sehingga total penambahan luas seluruh káwasan penelitian menjadi $1,097 \mathrm{~km}^{2}$. Data lengkap mengenai komposisi luas setelah penambahan pohon pereduksi polusi udara disajikan pada Tabel 27 berikut ini 
Tabel 27 Rekapitulasi komposisi penutupan lahan setelah penambahan pohon

\begin{tabular}{|c|c|c|c|c|c|}
\hline \multirow[b]{2}{*}{ Nama Jalan } & \multicolumn{4}{|c|}{ Komposisi Penutupan Lahan (km2) } & \multirow[b]{2}{*}{$\begin{array}{l}\text { Total } \\
\text { area }\end{array}$} \\
\hline & Pohon & $\begin{array}{l}\text { Perkerasan } \\
\text { Jalan }\end{array}$ & $\begin{array}{c}\text { Kawasan } \\
\text { Urban }\end{array}$ & $\begin{array}{c}\text { Penambahan } \\
\text { Pohon } \\
\text { Rekomendasi }\end{array}$ & \\
\hline JL. Padjajaran & 0,0633 & 0,2874 & 0,2047 & 0,0123 & 0,5678 \\
\hline JL. Dadali & 0,0134 & 0,0178 & 0,0218 & 0,0043 & 0,0573 \\
\hline JL. Raya Empang & 0,0022 & 0,0067 & 0,0060 & 0,0005 & 0,0154 \\
\hline JL. Jalak Harupat & 0,0159 & 0,0163 & 0,0091 & 0,0033 & 0,0446 \\
\hline JL. Jendral Ahmad Yani & 0,0396 & 0,0452 & 0,0434 & 0,0031 & 0,1313 \\
\hline JL. Ir. H. $\bar{D}$ juanda & 0,0097 & 0,0369 & 0,0217 & 0,0004 & 0,0687 \\
\hline JL. Otto Iskikandar Dinata & 0,0043 & 0,0127 & 0,0062 & 0,0020 & 0,0252 \\
\hline JL. Pemuda & 0,0240 & 0,0225 & 0,0212 & 0,0023 & 0,0699 \\
\hline JL. R. E. Martadinata & 0,0102 & 0,0158 & 0,0240 & 0,0029 & 0,0529 \\
\hline JL. Jendrat:Sudirman & 0,0133 & 0,0225 & 0,0235 & 0,0049 & 0,0642 \\
\hline Total $\overline{\bar{\eta}}$ & 0,1958 & $\mathbf{0 , 4 8 3 9}$ & 0,3815 & $\mathbf{0 , 0 3 6 0}$ & 1,0972 \\
\hline Rata-rata & 0,0196 & 0,0484 & $\mathbf{0 , 0 3 8 2}$ & 0,0036 & 0,1097 \\
\hline
\end{tabular}

2. Analisa Kapasitas Cadangan Karbon Setelah Penambahan Pohon Hasil anâlisa CITYgreen setelah penambahan vegetasi rekomendasi terjadi peningkatan kapasitas cadangan karbon dari semula 1.029,34 ton bertambah sebanyak $-3,83$ ton sehingga totalnya adalah $1.033,17$ ton dengan kenaikan tiap tahunnya-8.012 ton/tahun, data lebih lengkapnya tersaji pada Tabel 28 berikut ini. Tabel 28 Rekapitulasi kapasitas cadangan karbon setelah penambahan pohon

\begin{tabular}{lrr}
\hline & \multicolumn{2}{c}{ Kapasitas Cadangan Karbon } \\
\cline { 2 - 3 } Nam̧a Jalan & $\begin{array}{c}\text { Sebelum Penambahan } \\
\text { Pohon Rekomendasi (ton) }\end{array}$ & $\begin{array}{c}\text { Setelah Penambahan } \\
\text { Pohon Rekomendasi (ton) }\end{array}$ \\
\hline JL. Padjajaran & 20,21 & 1,31 \\
JL. Dadali & 142,08 & 0,46 \\
JL. Raya Empang & 0,23 & 0,05 \\
JL. Jalak Harupat & 1,69 & 0,35 \\
JL. Jendral Ahmad Yani & 421,17 & 0,33 \\
JL. Ir. H. Djuanda & 1,03 & 0,05 \\
JL. Otto Iskandar Dinata & 45,58 & 0,21 \\
JL. Pemuda & 254,84 & 0,24 \\
JL. R. E. Martadinata & 1,08 & 0,31 \\
JL. Jendral Sudirman & 141,43 & 0,52 \\
\hline Total CO & $\mathbf{1 . 0 2 9 , 3 4}$ & $\mathbf{3 , 8 3}$ \\
\hline
\end{tabular}


3. Analisa Jasa Lingkungan Setelah Penambahan Vegetasi Rekomendasi

Analisa Jasa lingkungan atau nilai manfaat penghematan ekonomi yang telah diperoleh dari metode pemodelan CITYgreen setalah dilakukan penambahan pohon rekomendasi pada 10 jalan sampel penelitian terjadi peningkatan yang cukup besar pada polutan $\mathrm{O}_{3}$ yang semula $\$ 7.845,81$ menjadi $\$ 8.720,22$ atau setara dengan Rp 11.624.053,3 (\$1USD = IDR 13.333,33) dan peningkatan yang kurang signifikan terdapat pada polutan CO yang semula \$ 121,16 menjadi \$ 134,67 atau setara dengan Rp 179.515,11 (\$1USD = IDR 13.333,33). Data selengkapnya disajikan pada Gambar 35 berikut ini.

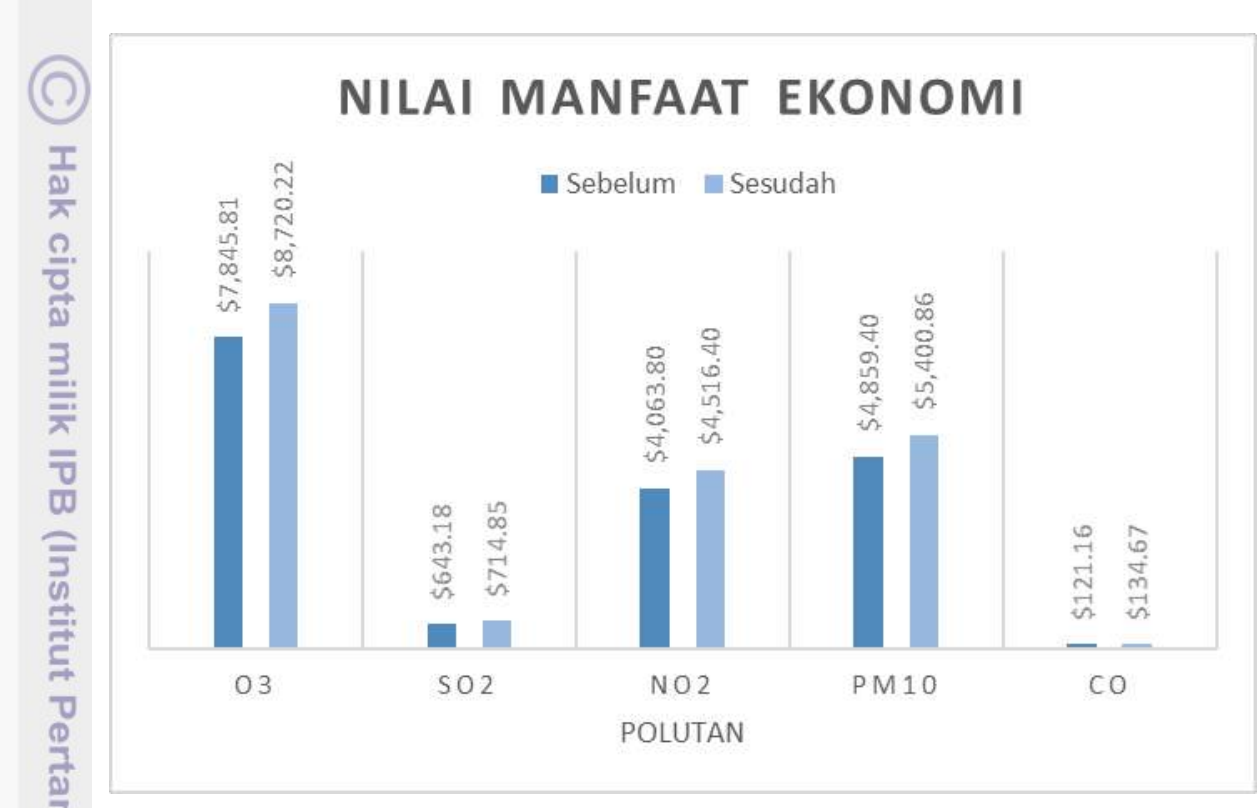

Gambar 35 Nilai manfaat ekonomi sebelum dan sesudah penambahan pohon rekomendasi

Total nilai manfaat ekonomi diberikan kanopi pohon dalam menyerap polusi udara pada 10 jalan sampel penelitian adalah Rp 233.777.941,56 per tahun, dan setelah penambahan pohon rekomendasi mengalami peningkatan menjadi $\mathrm{Rp}$ 259.826.601,71 per tahun. Data lebih lengkapnya disajikan pada Tabel 29.

Tabel 29 Perbandingan Nilai Manfaat Ekonomi Sebelum dan Sesudah Penambahan Pohon Rekomendasi

\begin{tabular}{lrr}
\hline \multicolumn{3}{c}{ Nilai Manfaat Ekonomi } \\
\hline \multicolumn{1}{c}{ Polutan } & \multicolumn{1}{c}{ Sebelum } & \multicolumn{1}{c}{ Sesudah } \\
\hline $\mathrm{O}_{3}$ & $\$ 7.845,81$ & $\$ 8.720,22$ \\
$\mathrm{SO}_{2}$ & $\$ 643,18$ & $\$ 714,85$ \\
$\mathrm{NO}_{2}$ & $\$ 4.063,80$ & $\$ 4.516,40$ \\
$\mathrm{PM} 10$ & $\$ 4.859,40$ & $\$ 5.400,86$ \\
$\mathrm{CO}$ & $\$ 121,16$ & $\$ 134,67$ \\
\hline TOTAL $\$$ & $\$ 17.533,35$ & $\$ 19.487,00$ \\
\hline TOTAL Rp & Rp 233.777.941,56 & Rp 259.826.601,71 \\
\hline
\end{tabular}

Analisa Konsentrasi Penyerapan Polutan Setelah Penambahan Vegetasi Rekomendasi 
Analisa Jasa lingkungan atau nilai manfaat reduksi polusi yang telah diperoleh dari metode pemodelan CITYgreen setelah dilakukan penambahan pohon rekomendasi pada 10 jalan sampel penelitian terjadi peningkatan yang I cukup besar pada polutan $\mathrm{O}_{3}$ yang semula 2.556,04 lbs menjadi 2.819,68 lbs atau setara dengan $1.141,09 \mathrm{~kg}(1 \mathrm{lbs}=0.40469 \mathrm{~kg})$, dan peningkatan yang kurang - signifikan terdapat pada polutan CO yang semula 282,94 lbs menjadi $312,15 \mathrm{lbs}$ 5 atau setara dengan $129.32 \mathrm{~kg}(1 \mathrm{lbs}=0.40469 \mathrm{~kg})$. Data yang lebih lengkapnya 믈 disajikan pada Gambar 36 berikut ini.

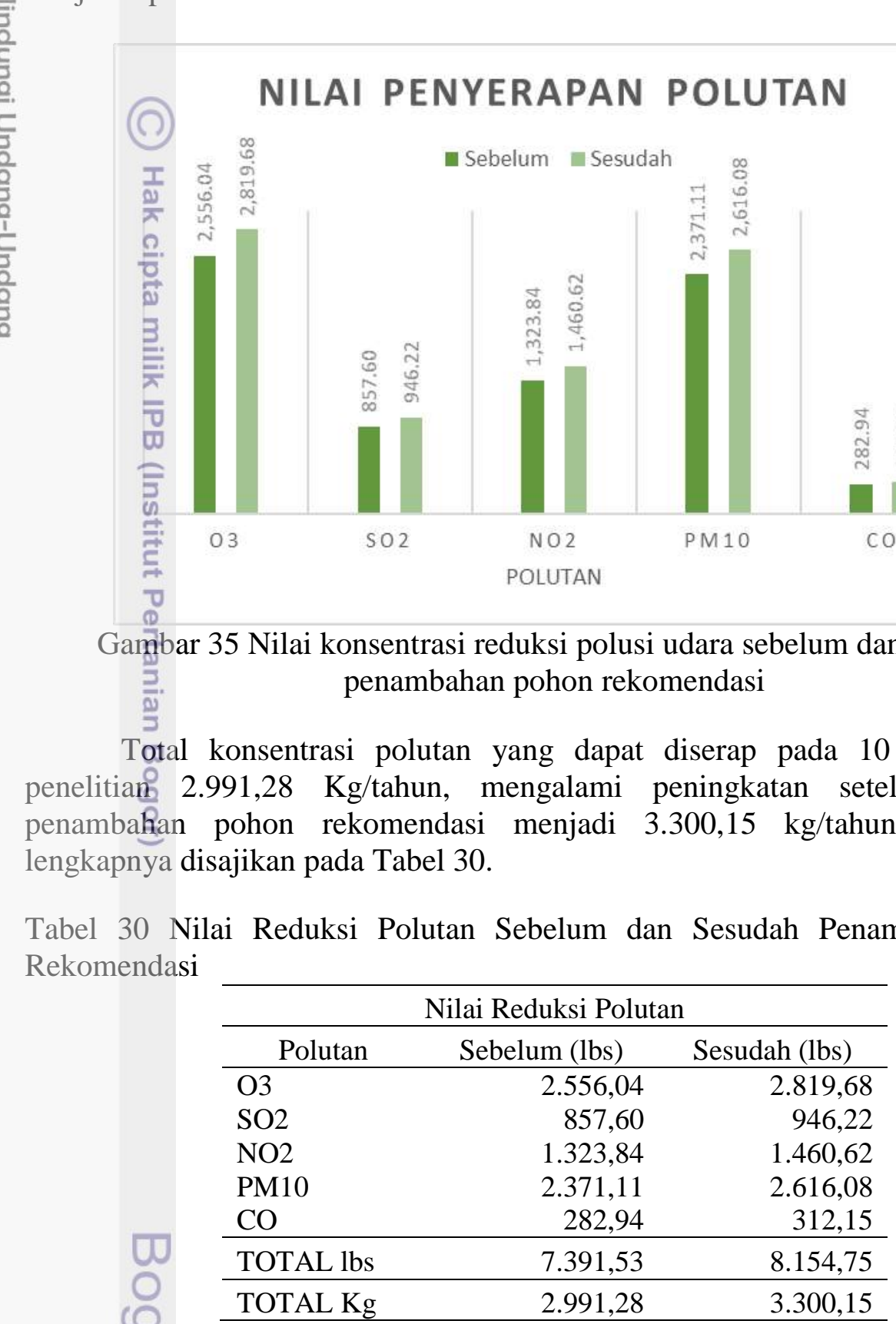




\section{SIMPULAN DAN SARAN}

\section{Simpulan}

1. Nilai jasa lingkungan diberikan kanopi pohon dalam menyerap polusi udara pada 10 jalan sampel penelitian adalah Rp 233.777.941,56 per tahun, setelah penambahan pohon rekomendasi mengalami peningkatan menjadi $\mathrm{Rp}$ 259.826.601,71 per tahun, dan total konsentrasi polutan yang dapat diserap pada 10 sampel jalan penelitian $2.991,28 \mathrm{Kg} /$ tahun, mengalami peningkatan setelah dilakukan penambahan pohon rekomendasi menjadi 3.300,15 沓g/tahun,

2. KKapasitas cadangan karbon yang diperoleh Kota Bogor pada 10 ruas jalan Sampel penelitian adalah 1.029,34 ton dengan kenaikan tiap tahunnya sekitar 8,011 ton/tahun, dan setelah dilakukan penambahan pohon menjadi $1.033,17$ ton dengan kenaikan tiap tahunnya 8,012 ton/tahun, dan

3. Pohon yang direkomendasikan untuk ditanam di 10 ruas jalan sampel $\bar{p}$ enelitian dalam upaya meningkatkan efektifitas penyerapan polusi udara âdalah Bunga kupu-kupu (Bauhinia purpurea), Bungur (Langerstromia $\overline{\bar{s}}$ peciose), Cemara gembel (Cupressus papuana), Kenari (Canarium Łommuane), Mahoni (Swietenia mahogany), dan Pinus (Pinus merkusii) dengan jumlah pohon yang bisa ditambahkan adalah 505 pohon.

\section{Saran}

Alangkah baiknya jika penelitian ini bisa menggunakan perangkat lunak pengolah data jasa lingkungan yang lebih baru salah satunya adalah $i$-Tree Eco Version 6.0 keluaran tahun 2015. I-Tree Eco merupakan perangkat lunak yang dikembangkan oleh American Forest, dimana perangkat lunak ini lebih akurat dan canggih dibandingkan CITYgreen 5.0, namun perangkat lunak ini memerlukan data kondisi emisi yang dihitung tiap jam selama 1 tahun sehingga perlu dilakukan penelitian yang lebih lanjut. 


\section{DAFTAR PUSTAKA}

I Agus P dan Badriah S. 2012. Slide Mata Kuliah Manajemen Jasa Lingkungan dan Dampak. Bogor (ID): IPB Pr.

Agustini. M.1994. Identifikasi Ciri Arsitektur dan Kerapatan Stomata Dua Puluh Lima Jenis Pohon Suku Leguminose untuk Elemen Lanskap Tepi Jalan. [Skripsi] Bogor (ID): Jurusan Budidaya Pertanian, Fakultas Pertanian IPB

Al-Hakim AH. 2014. Evaluasi Tanaman dalam Mereduksi Polusi Berdasarkan Karakteristik Fisik Pohon pada Jalur Hijau Jalan Pajajaran Bogor. Skripsi. Bogor (ID): IPB

American_Forest. 2002. CITYgreen 5.0: User Manual. Washington DC (US): American Forest.

[BMKG] Badan Meteorologi dan Geofisika Stasiun Klimatologi Dramaga Bogor. 2015. Data Curah Hujan Bulanan Januari 2010-September 2015. Bogor (ID): $\mathrm{BMKG}$

[BPLH] Badan Pengelola Lingkungan Hidup Kota Bogor. 2015. Laporan Kègiatan Monitoring dan Evaluasi Rencana Aksi Daerah: Pengurangan Emisi Gas Rumah Kaca. Bogor (ID): PT. Fasade Kobetama Internasional.

[BAPPEDA] Badan Perencanaan Pembangunan Daerah. 2011. Masterplan Transportasi Kota Bogor: Laporan Hasil Penyusunan Data Base. Bogor (ID): BAPPEDA Kota Bogor

Booth NK. 1983. Basic Elements of Landscape Architecture Design. Illinois (US): Waveland Press Inc.

Bridwell FM. 2003. Landscape Plants: Their Identification, Culture, and Use, Seccond Edition. New York (US): Delmar

Carpenteg, PL, TD Walker, FO Lanphear. 1975. Plants in the Landscape. San Fransisco (US): W.H. Freeman and Company.

Dahlan, EN. 1989. Studi Kemampuan Tanaman Dalam Menjerap dan Menyerap Timbal Emisi dari Kendaraan Bermotor [Tesis]. Bogor (ID): Pascasarjana Institut Pertanian Bogor. Tidak dipublikasikan

[DKP] Dinas Kebersihan dan Pertamanan Kota Bogor. 2015. Data Inventarisasi di Jalan Protokol Kota Bogor. Bogor (ID): DKP Kota Bogor

[DLLAJ] Dinas Lalu Lintas dan Angkutan Jalan. 2015. Data Jumlah Kendaraan Bermotor di Kota Bogor Tahun 2015. Bogor (ID): DLLAJ Kota Bogor

[DIRJEN Bina Marga] Direktorat Jenderal Bina Marga. 1996. Tata Cara Perencanaan Teknik Lanskap Jalan. Jakarta (ID): Departemen Pekerjaan Umum

2010. Pedoman Teknis Penanaman Pohon pada Sistem Jaringan Jalan. Jakarta (ID): Departemen Pekerjaan Umum.

Fakuara, Y. 1986. Hutan Kota: Peranan dan Permasalahannya. Bogor (ID): Departeman Manajemen Hutan. Fakultas Kehutanan, IPB

Grey, GW dan FJ Deneke. 1978. Urban forestry. New York: John Wiley and Sons, Inc.

Hakim R. dan Utomo H. 2003. Komponen Perancangan Arsitektur Lanskap. Jakarta (ID): Bumi Aksara.

Hasim IS. 2009. Tanaman Hias Indonesia. Jakarta (ID): Penebar Swadaya 
Hermawan R, Kusmana C, Nasrullah N, dan Prasetyo LB. 2011. Jerapan Debu dan Partikel Timbal (Pb) oleh Daun Berdasarkan Letak Pohon dan Posisi Tajuk: Studikasus Jalur Hijau Acasia mangium, Jalan TOL Jagorawi. Media Konservasi Vol. 16, No. 3: 101-107

Hidayat, IW. 2008. Evaluasi Jalur Hijau Jalan Sebagai Penyangga Lingkungan Sekitarnya dan Keselamatan Pengguna Jalan Bebas Hambatan Jagorawi [Tesis]. Program Pascasarjana Institut Pertanian Bogor. Tidak dipublikasikan.

Hinkle DE, Wiersma W, Jurs SG. 2003. Applied Statistics for the Behavioral Sciense Fifth edition. Boston (USA): Houghton Miffin Co. Ltd.

Intergovernmental Panel on Climate Change (IPCC). 2014. Climate Change Impacts in Hawaii - A summary of climate change and its impacts to

- Hawaii's ecosystems. Hawaii (US): University of Hawaii at Mänoa Sea Grant College Program and communities.

Kementrian Pekerjaan Umum. 2004. Pedoman konstruksi dan bangunan: Penentuan Klasifikasi dan Fungsi Jalan di Kawasan Perkotaan. Jakarta (ID): Kementrian Pekerjaan Umum.

Lestäri G, Kencana IP, dan Nasrullah N. 2011. Galeri Tanaman Lanskap. Jakarta (ID): Penebar Swadaya

Now̧ak DJ. Crane DE, dan Stevens JC. 2006. Air pollution removal by urban trees and shrubs in the United States. Urban Forestry and Urban Greening 4:115-123. (US)

. Greenfield EJ, Hoehn RE, Lapoint E. 2013. Carbon storage and Sequenstration by Trees in Urban and Community Areas of the United States. Eviroenmental Pollution 2013 (178): 229-236. (US)

Nugrahani P, Nasrullah N, dan Sisworo EL. 2006. Risalah seminar ilmiah: Faktor Fisiologi Tanaman Tepi Jalan yang Menentukan Kemampuan Serapan Polusi Udara Gas ${ }^{15} \mathrm{NO}_{2}$. Bogor (ID): Program Pascasarjana Institut Pertanian Bogor.

Peraturan Pemerintah No. 12 Tahun 2009 tentang Pedoman penyediaan Ruang

$\cong$ Non-terbuka Hijau (RNTH) dan Ruang Terbuka Hijau (RTH) di Kawasan Perkotaan

Rao M.N, dan H. V. N. Rao 1994. Air Pollution. New Delhi (IN): Tata Mc GrawHill Publishing Co.ltd.

Sriyanto. 2007 dalam Supriyanto. 2008. Teknik Pemanfaatan Jasa Lingkungan dan Wisata Alam. Bogor (ID): Departemen Kehutanan Pusdiklat Kehutanan Bogor

Stevens D, Huntington L, and Key R. 1994. Garden Design Construction and Planting. London (GB): Ward Lock

Sutopo M.F. 2011. Pengembangan Kebijakan Jasa Lingkungan dalam Pengelolaan Air Minum (Studi Kasus DAS Cisadane Hulu). Disertasi. Bogor (ID): Sekolah Pascasarjana IPB

Taihuttu, Hermina Neltje. 2001. Studi Kemampuan Tanaman Jalur Hijau Jalan Sebagai Penjerap Partikulat Hasil Emisi Kendaraan Bermotor [Tesis]. Bogor (ID): Program Pascasarjana Institut Pertanian Bogor. Tidak dipublikasikan. 


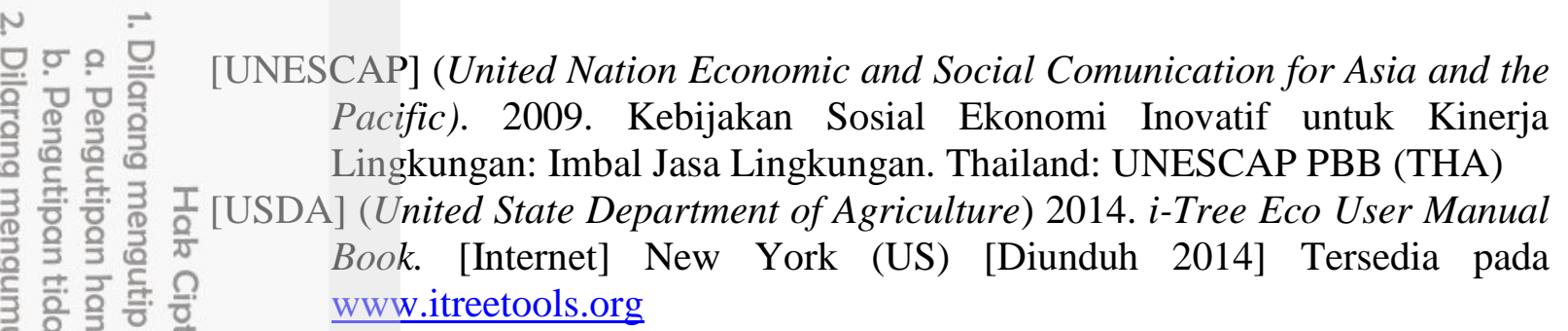




\section{LAMPIRAN}

Lampiran 1 Hasil analisa CITYgreen pada Jl. Jalak Harupat.

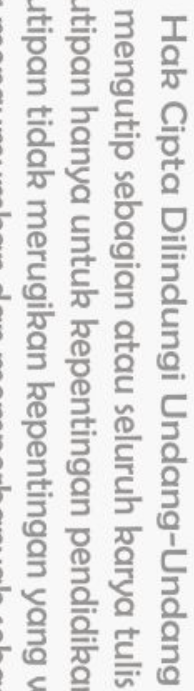

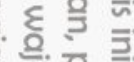

윽 옹

\section{Analysis Report}

OITIgreen

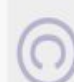

\section{Site Statistics}

Scenario: Current Conditions Area:

0.01 sq. miles

8.08 acres

3.27 hectares
Landcover Distribution:

Acres

$0 \%$ Cropland

$49.98 \%$ Impervious

$0 \%$ OpenSpace/Pasture/Meadow

$0 \%$ Shrubs

48.63\% Tree Canopy

$27.68 \%$ Urban Land Use

$0 \%$ Water

Ecological Benefits

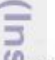

Qir Pollution Removal

Air? Quality Reference City: Average - 10 Cities
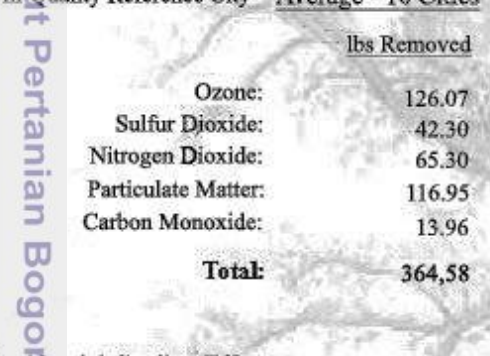

Sulfur Dioxide:

Nitrogen Dioxide:

Particulate Matter

Carbon Monoxide:

Total:

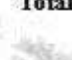

Residential Cooling Effects

Average Annual Cooling Cost per Home

Number of Homes:

Savings from Trees:

Savings from Roofs:

Total Savings:

Savings per Home:

Kilowatt-hours Saved:

KWHs Saved per Home:

Carbon Generation Avoided:

Carbon Generation Avoided

per Home:

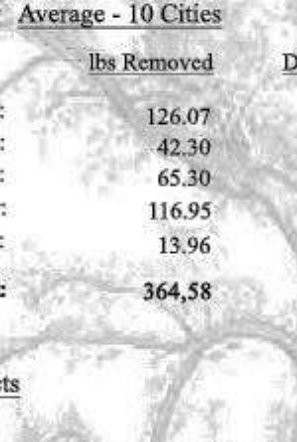

Dollar Value

$\$ 386,99$

$\$ 31,72$

$\$ 200,45$

$\$ 239,69$

$\$ 5,98$

$\$ 864,83$

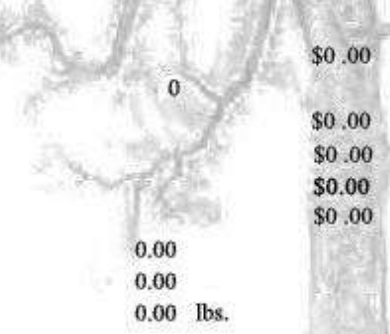

$0.00 \mathrm{lbs}$

0.00 lbs.
Carbon Storage and Sequenstration Age Distribution of Trees:

Carbon Storage:

Carbon Sequestration:

Stormwater Control

Average 2-yr, 24-hour Rainfall: $\quad 0.50$ in

Conditions:

Current w/otrees*

Curve Numbe

Runoff (in.):

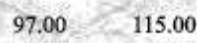

$0.26-1.07$

Storage volume need to

mitigate the change in peak $\quad 33,897.45 \quad \mathrm{cu} . \mathrm{ft}$.

flow:

Construction cost:

$\$ 2.00$ per cu. ft.

Total

$\$ 77,794.90$

*Replaced by default landcover: Imperviouse Surface: Buildings struetures: All other buildings

Economic Benefit Summary

Annual Air Pollution Removal Savings:

$\$ 864,83$

Annual Energy Savings:

$\$ 0$

Annual Stormwater Savings*:

\$0

Total Annual Savings:

$\$ 864,83$

-Anvual stormwater savings is based on financing over 20 yaers at $6 \%$ 


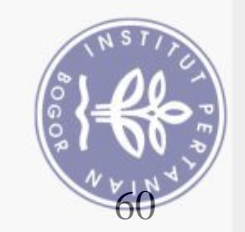

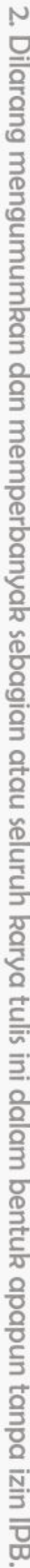

Lampiran 2 Hasil analisa CITYgreen pada Jl. Dadali

을 을 을

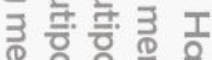

을 을 을

응을 음

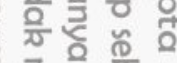

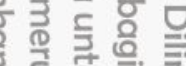

을 흔 을

율 율 을

政

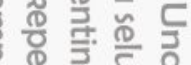

殼 을 至

븡 뭉

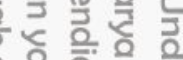

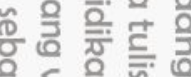

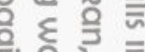

을 융

하을 을

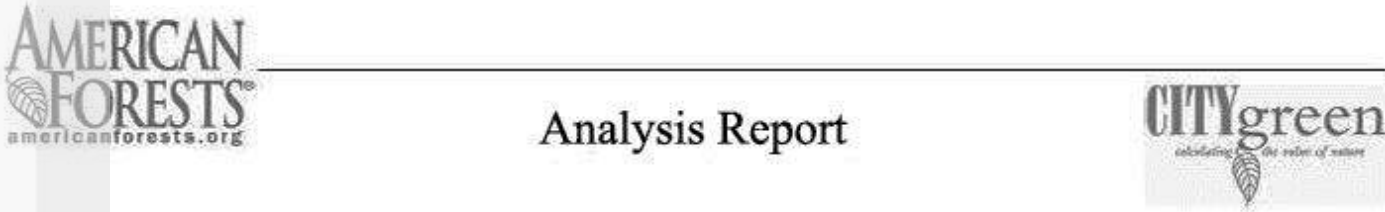

Analysis Area: Jalan Dadali

Scenario: Current Conditions Area:

0.02 sq. miles

11.48 acres

4.64 hectares

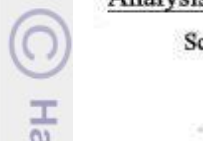

$\frac{1}{\pi}$

Air Pollution Remova

Air $\mathbf{Q}$ uality Reference City Average -10 Cities
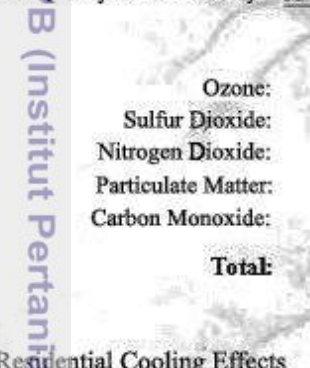

Sulfur Dioxide:

Nitrogen Dioxide:

Particulate Matter

Carbon Monoxide:

Total:

Residential Cooling Effects

Axerage Annual Cooling

Cost per Home:

Number of Homes

Savings from Trees:

3 Savings from Roofs:

Total Savings:

Savings per Home:

Kilowatt-hours Saved:

KWHs Saved per Home:

Carbon Generation Avoided:

Carbon Generation Avoided

per Home:

306,21 lbs Removed

\section{Site Statistics}

Landcover Distribution: Acres

$0 \%$ Cropland $\quad 0.00$

$38.40 \%$ Impervious $\quad 4.41$

$0 \%$ OpenSpace/Pasture/Meadow $\quad 0.00$

$0 \%$ Shrubs 0.00

$28.77 \%$ Tree Canopy $\quad 3.30$

$47.02 \%$ Urban Land Use $\quad 5.40$

$0 \%$ Water 0.00

Ecological Benefits

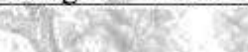

Carbon Storage and Sequenstration

Age Distribution of Trees: $\quad$ Average or Unknown

Carbon Storage: $142.08 \quad$ tons

Carbon Sequestratio

1.11 pounds/year

$\begin{array}{lll}54.84 & \$ 168,36 & \text { Stormwater Control } \\ 98.23 & \$ 201,31 & \end{array}$

$98.23 \quad$ - $\$ 201,31$

$11.72 \quad \$ 5,02$

$\$ 726,36$

Average 2-yr, 24-hour Rainfall: $\quad 0.50$ in
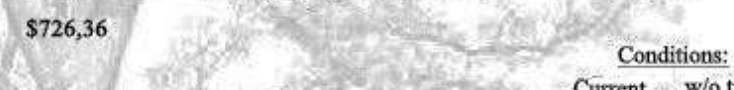

current w/o trees*

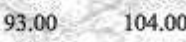

Curve Number:

$0.11 \quad 1.73$

Storage volume need to

mitigate the change in peak $\quad 45,399.89 \quad \mathrm{cu}$. $\mathrm{ft}$.

flow:

Construction cost:

$\$ 2.00$ per cu. ft.

Total

$\$ 90,799.78$

*Replaced by default landcover: Imperviouse Surface: Buildings' structures: All other buildings

\section{Economic Benefit Summary}

Annual Air Pollution Removal Savings:

$\$ 726,36$

Annual Energy Savings:

$\$ 0$

Annual Stormwater Savings*:

Total Annual Savings:

$\$ 726,36$

-Anvual stormwster savings is based on financing over 20 yaers at $6 \%$ 
Air $\bar{Q}$ uality Reference City $=$ Average -10 Cities

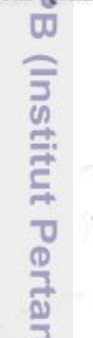

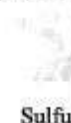

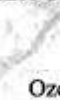

Ozone

Nitrogen Dioxide:

Particulate Matter:

Carbon Monoxide:

\section{lbs Removed}

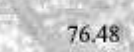

76.48
25.66

25.66
39.61

39.61

8.47

Total:

221,16

\section{Analysis Report}

Regîisential Cooling Effects Average Annual Cooling 00. Cost per Home

Number of Homes

Savings from Trees:

5 Savings from Roofs: Total Savings: Savings per Home: Kilowatt-hours Saved: KWHs Saved per Home: Carbon Generation Avoided: Carbon Generation Avoided per Home:

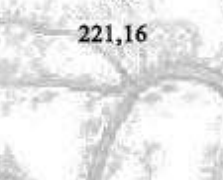

$\underline{\text { Site Statistics }}$

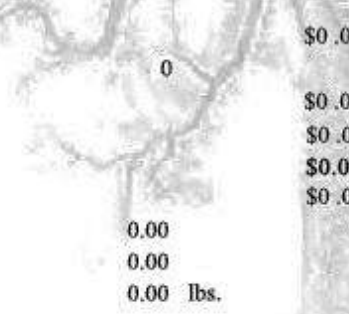

Ecological Benefits

Landcover Distribution:

Acres

$0 \%$ Cropland

$58.82 \%$ Impervious

$0 \%$ OpenSpace/Pasture/Meadow

$0 \%$ Shrubs

$15.36 \%$ Tree Canopy

$34.62 \%$ Urban Land Use

$0 \%$ Water
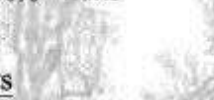

Carbon Storage and Sequenstration

Age Distribution of Trees:

Carbon Storage: $\quad 1.03 \quad$ tons

Carbon Sequestration:

Stormwater Control

$\$ 121,59$

$\$ 3,62$

$\$ 524,58$

Average 2-yr, 24-hour Rainfall:

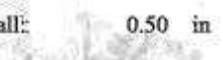

Conditions:

Current w/o trees*

Curve Number:

Runoff (in.):

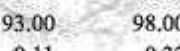

$0.11 \quad 0.32$

Storage volume need to

mitigate the change in peak $\quad 7,350.81 \quad \mathrm{cu} . \mathrm{ft}$.

flow:

Construction cost:

$\$ 2.00$ per cu. ft.

Total

$\$ 14,701.62$

*Replaced by default landcover: Imperviouse Surface: Buildings' struetures: All other buildings

\section{Economic Benefit Summary}

Annual Air Pollution Removal Savings:

Annual Energy Savings:

$\$ 524,60$

Annual Stormwater Savings*:

Total Annual Savings:

$\$ 524,60$

-Anpual stormwster savings is based on financing over 20 yaers at $6 \%$ 


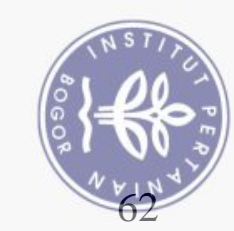

Lampiran 4 Hasil analisa CITYgreen pada Jl. Raya Empang

누윽

$\begin{array}{ll}\text { AMERICAN } & \\ \text { FORESTS } & \text { Analysis Report }\end{array}$

\section{OITIgreen}

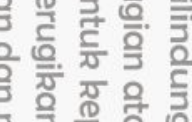

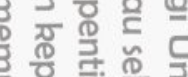

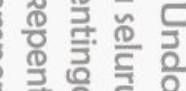

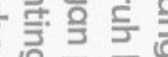

을 일

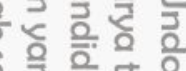

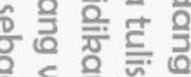

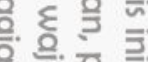

윽 융

两 离

\section{$\underline{\text { Site Statistics }}$}

Analysis Area: Jalan Raya Empang Scenario: Current Conditions Area: 3.53 acres 1.43 hectares
0.01 sq. miles

Landcover Distribution:

Acres

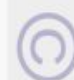

\section{Ayir Pollution Removal}

AipQRuality Reference City: Average- 10 Cities
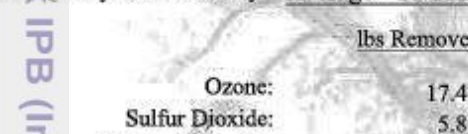

Sulfur Dioxide: Nitrogen Dioxide:

Particulate Matter:

Carbon Monoxide:

Total:

$\frac{0}{2}$

eidential Cooling Effect Giverage Annual Cooling

Cost per Home:

D. Number of Homes:

Savings from Trees:

Savings from Roofs:

ㄱ. Total Savings:

Savings per Home: Kilowatt-hours Saved: KWHs Saved per Home: Carbon Generation Avoided: Carbon Generation Avoided

$$
\text { per Home: }
$$

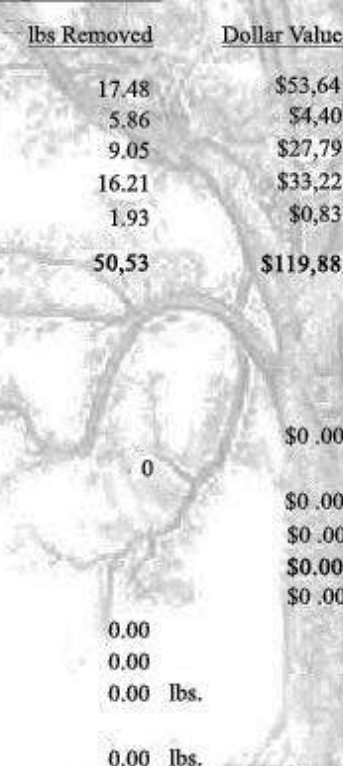

\section{$0 \%$ Cropland}

$46.71 \%$ Impervious

$0 \%$ OpenSpace/Pasture/Meadow

$0 \%$ Shrubs

$15.45 \%$ Tree Canopy

$42.09 \%$ Urban Land Use

$0 \%$ Water

\section{Ecological Benefits}

Carbon Storage and Sequenstration

Age Distribution of Trees: $\quad$ Average or Unknown Carbon Storage: $\quad 0.23 \quad$ tons

Carbon Sequestration:

0.00 pounds/year

Stormwater Control

$\$ 0,83$ Average 2-yr, 24-hour Rainfall: $\quad 0.50$ in

Conditions:

Current w/otrees*
Curve Number:

Runoff (in.):

Storage volume need to

mitigate the change in peak

flow:

Construction cost:

Total

$\$ 2,302.62$

*Replaced by default landcover: Imperviouse Surface: Buildings' struetures: All other buildings

\section{Economic Benefit Summary}

Annual Air Pollution Removal Savings:

Annual Energy Savings:

Annual Stormwater Savings*:

Total Annual Savings:

-Ansual stormwater savings is based on financing over 20 yaers at $6 \%$ 
Lampiran 5 Hasil analisa CITYgreen pada Jl. Jend. Ahmad Yani

$\overrightarrow{0}$ $\begin{array}{ll}\text { AMERICAN } & \\ \text { AORESTS } & \text { Analysis Report }\end{array}$

Site Statistics

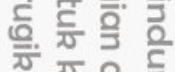

윯 윰

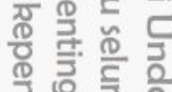

喜 을 至

능 뭉

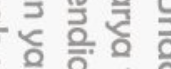

。를 을

ํㅡㄹ 을

윽융

宁 $\frac{\mathrm{D}}{\mathrm{F}}$

要

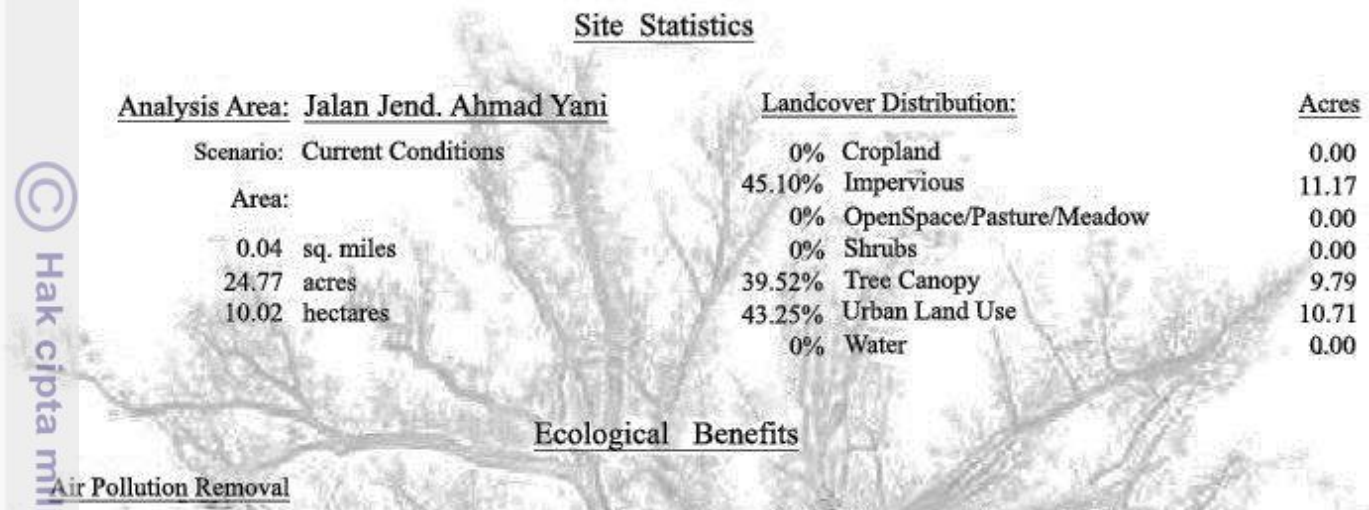

Air Pollution Removal

AirQuality Reference City Average - 10 Cities

Carbon Storage and Sequenstration

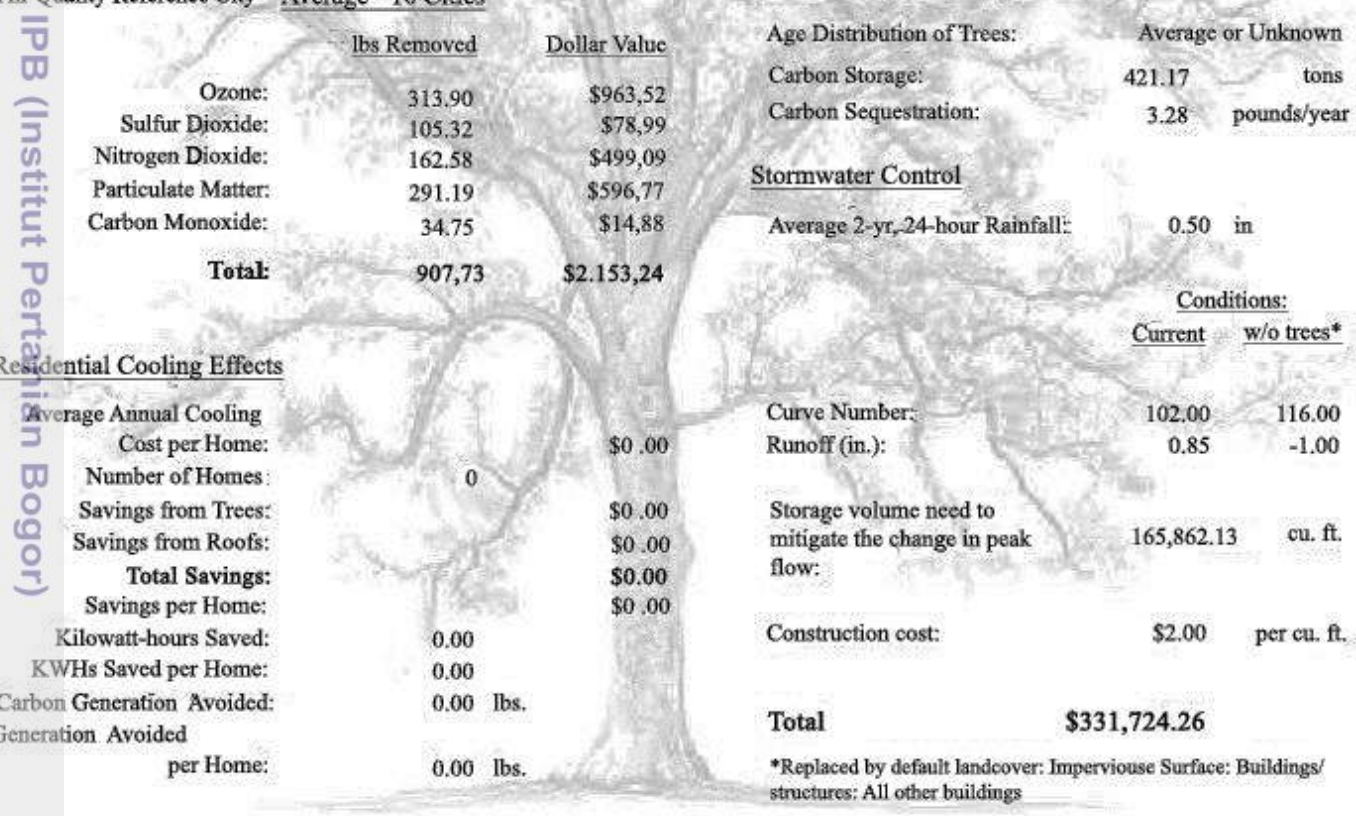

Economic Benefit Summary

Annual Air Pollution Removal Savings:

$\$ 2,153,24$

Annual Energy Savings:

Annual Stormwater Savings*:

Total Annual Savings:

-Anvual stormwater savings is based on financing over 20 yaers at $6 \%$ 


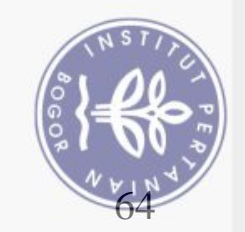

서을

Lampiran 6 Hasil analisa CITYgreen pada Jl. Otto Iskandar Dinata

응 뜰 을

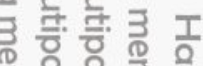

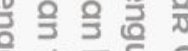

응 을 훙

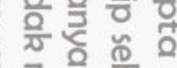

고을 을 을

응 뜰 을 은

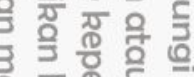

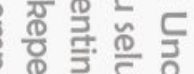

壱을 을 을

응 뭉

象象

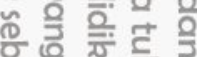

\& 을

응뭉

울 을 을

\section{Site Statistics}

Analysis Area: Jalan Otto Iskandar Dinata Scenario: Current Conditions

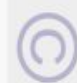

(O)

항 Zir Pollution Removal

Air Fuality Reference City: Average -10 Cities
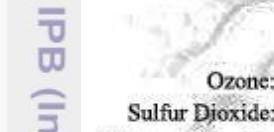

Nitrogen Dioxide:

Particulate Matter

Carbon Monoxide:

Total:

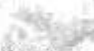

Residential Cooling Effects Average Annual Cooling

\section{Cost per Home}

D. Number of Homes

- Savings from Trees:

Savings from Roofs:

근 Total Savings:

Savings per Home:

Kilowatt-hours Saved:

KWHs Saved per Home:

Carbon Generation Avoided:

Carbon Generation Avoided

per Home:
Landcover Distribution:

Acres

$0 \%$ Cropland

$60.56 \%$ Impervious

$0 \%$ OpenSpace/Pasture/Meadow $\quad 0.00$

$0 \%$ Shrubs

$20.50 \%$ Tree Canopy $y=1.06$

$29.51 \%$ Urban Land Use

$0 \%$ Water $\quad 0.00$

Ecological Benefits

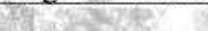

Carbon Storage and Sequenstration

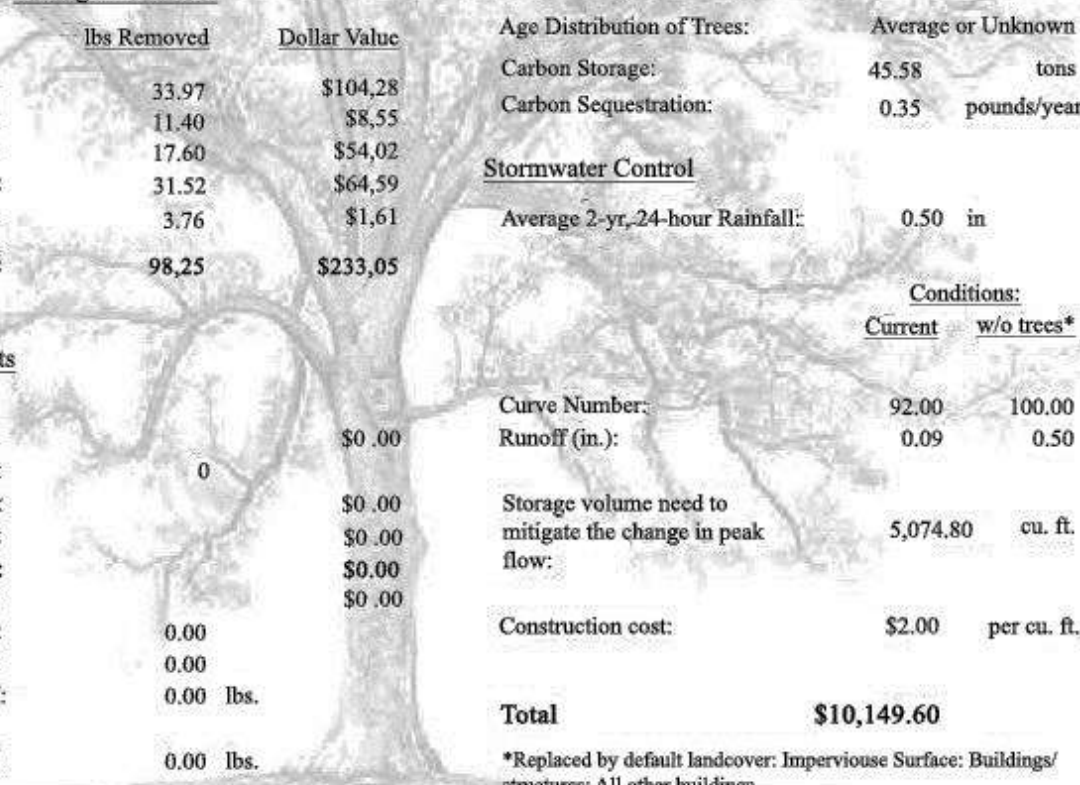
*Replaced by default landeover: Imperviouse Surface: Buildings
structures: All other buildings

\section{Economic Benefit Summary}

Annual Air Pollution Removal Savings:

$\$ 233,04$

Annual Energy Savings:

Annual Stormwater Savings*

$\$ 0$

Total Annual Savings:

$\$ 233,04$

-Anbual stormwrater savings is based on financing over 20 yaers at $6 \%$ 


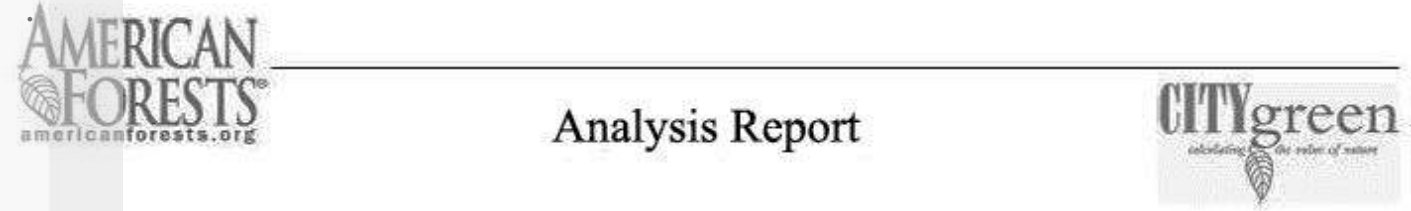

\section{Site Statistics}

Analysis Area: Jalan Raya Padjajaran Scenario: Current Conditions Area:

0.21 sq. miles

136.59 acres

55.28 hectares

\section{Landcover Distribution:}

$0 \%$ Cropland

$52.00 \%$ Impervious

$0 \%$ OpenSpace/Pasture/Meadow

$0 \%$ Shrubs

$34.39 \%$ Tree Canopy

$37.04 \%$ Urban Land Use $0 \%$ Water
Acres

0.00

71.03

0.00

0.00

46.97

50.60 0.00

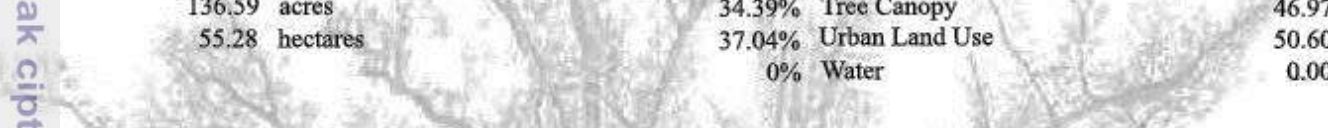

(i)

Air Pollution Removal

Air Quality Reference City Average -10 Cities

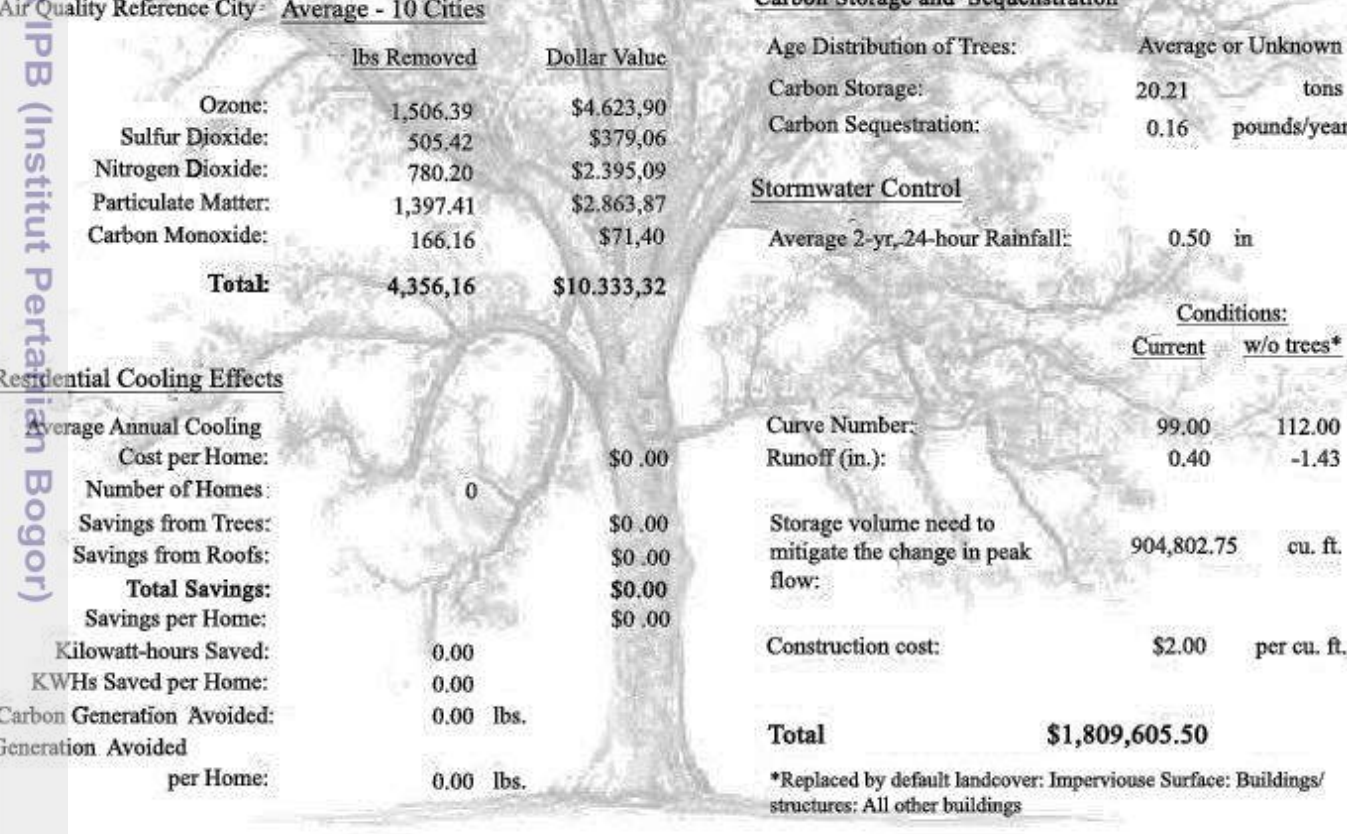

Economic Benefit Summary

Annual Air Pollution Removal Savings:

$\$ 10,333.32$

Annual Energy Savings:

Annual Stormwater Savings*:

Total Annual Savings:

$\$ 10,333.32$

-Anvual stormwater savings is based on financing over 20 yaers at $6 \%$ 


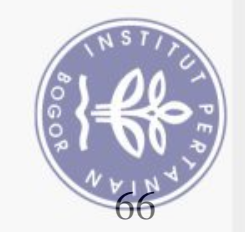

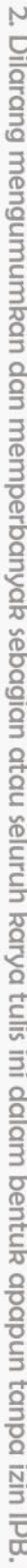

Site Statistics

Analysis Area: Jalan Pemuda Scenario: Current Conditions Area:

0.01 sq. miles 13.83 acres 5.60 hectares
Landcover Distribution:

Acres

$0 \%$ Cropland

$40.17 \%$ Impervious

$0 \%$ OpenSpace/Pasture/Meadow

$0 \%$ Shrubs

$42.82 \%$ Tree Canopy

$37.80 \%$ Urban Land Use

$0 \%$ Water

\section{Ecological Benefits}

Air Pollution Removal

Airguality Reference City Average-10 Cities
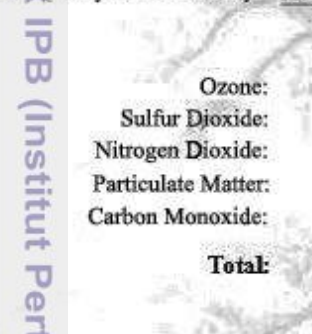

Sulfur Dioxide:

Nitrogen Dioxide:

Particulate Matter:

Carbon Monoxide: $\quad 21.02$

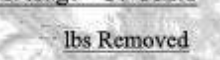

Dollar Value

$\$ 583,01$

$63.73 \quad \$ 47,79$

$98.37 \quad \$ 301,99$

176.19
9361,09

Total:

Resfdential Cooling Effects 갈age Annual Cooling 5 Cost per Home:

D. Number of Homes:

Savings from Trees:

Savings from Roofs:

Total Savings:

Savings per Home: Kilowatt-hours Saved: KWHs Saved per Home: Carbon Generation Avoided: Carbon Generation Avoided per Home:
549,24
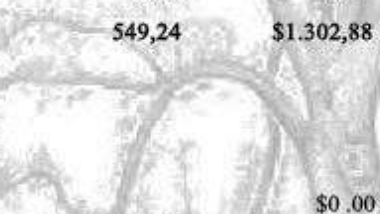

$\$ 0.00$

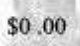

$\$ 0.00$
$\$ 0.00$

$\$ 0.00$

$\$ 0.00$

0.00

0.00

0.00 lbs.

$0.00 \mathrm{lbs}$.
Carbon Storage and Sequenstration

Age Distribution of Trees:

bon Storage:

Carbon Sequestration:

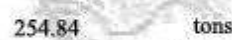

1.98 pounds/year

Stormwater Control

Average 2-yr, 24-hour Rainfall: $\quad 0.50$ in Conditions:

Current w/otrees*

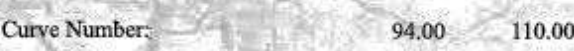

Runoff (in.):

$0.14 \quad-2.50$

Storage volume need to

mitigate the change in peak $\quad \mathrm{cu}$. $\mathrm{ft}$.

flow: $\quad-74,248.21$

Construction cost:

$\$ 2.00$ per cu. ft.

Total

$\$-148,496.42$

*Replaced by default landcover: Imperviouse Surface: Buildings' struetures: All other buildings

\section{Economic Benefit Summary}

Anmual Air Pollution Removal Savings:

$\$ 1,302.88$

Annual Energy Savings:

Annual Stormwater Savings*:

Total Annual Savings:

-Anvual stormwater savings is based on financing over 20 yaers at $6 \%$ 


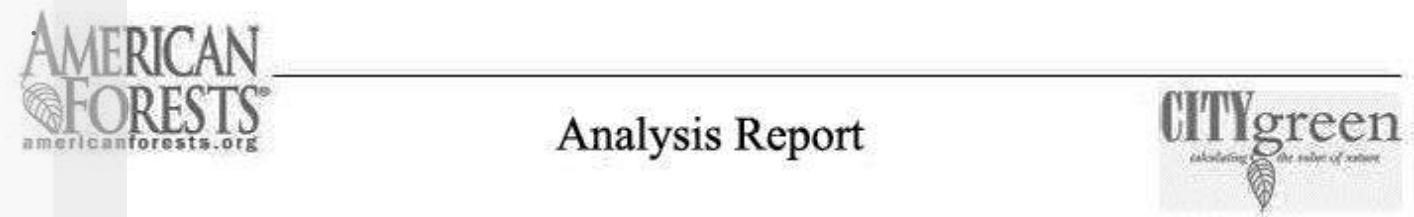

\section{Site Statistics}

Analysis Area: Jalan R.E. Martadinata Scenario: Current Conditions Area:

0.02 sq. miles

10.95 acres 4.43 hectares

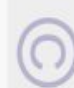

$\frac{1}{\frac{1}{\pi}}$

\section{3} Air Pollution Removal

Air Quality Reference City: Average - 10 Cities

ए

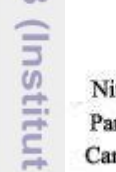

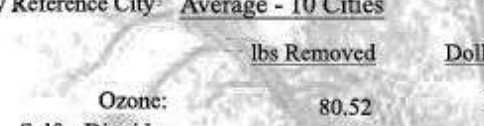

Sulfur Dioxide:

Carbon Matter

Total:

$\frac{7}{2}$

i)

Restidential Cooling Effects

Arerage Annual Cooling Cast per Home:

DU Number of Homes:

(6) Savings from Trees:

Savings from Roofs: Total Savings: Savings per Home: Kilowatt-hours Saved: KWHs Saved per Home: Carbon Generation Avoided: Carbon Generation Avoided per Home:

$\begin{array}{rr} & \text { Dollar Value } \\ 80.52 & \$ 247,15 \\ 27.01 & \$ 20,26\end{array}$

$41.70 \quad \$ 128,02$

\begin{tabular}{l|l}
74.69 & $\$ 153,07$
\end{tabular}

$8.91 \quad \$ 3,82$

232,84

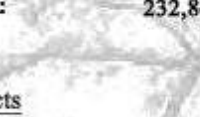

$\$ 552,32$
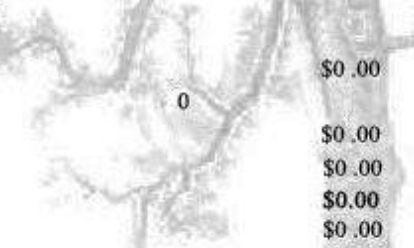

0.00

0.00

0.00 lbs.

0.00 lbs.
Landcover Distribution:

Acres

$0 \%$ Cropland

$35.69 \%$ Impervious

$0 \%$ OpenSpace/Pasture/Meadow

$0 \%$ Shrubs

$22.93 \%$ Tree Canopy

$54.12 \%$ Urban Land Use

$0 \%$ Water

0.00

3.91

0.00

0.00

2.51

5.93

0.00

\section{Economic Benefit Summary}

Annual Air Pollution Removal Savings:

$\$ 552.32$

Annual Energy Savings:

Annual Stormwater Savings*: 

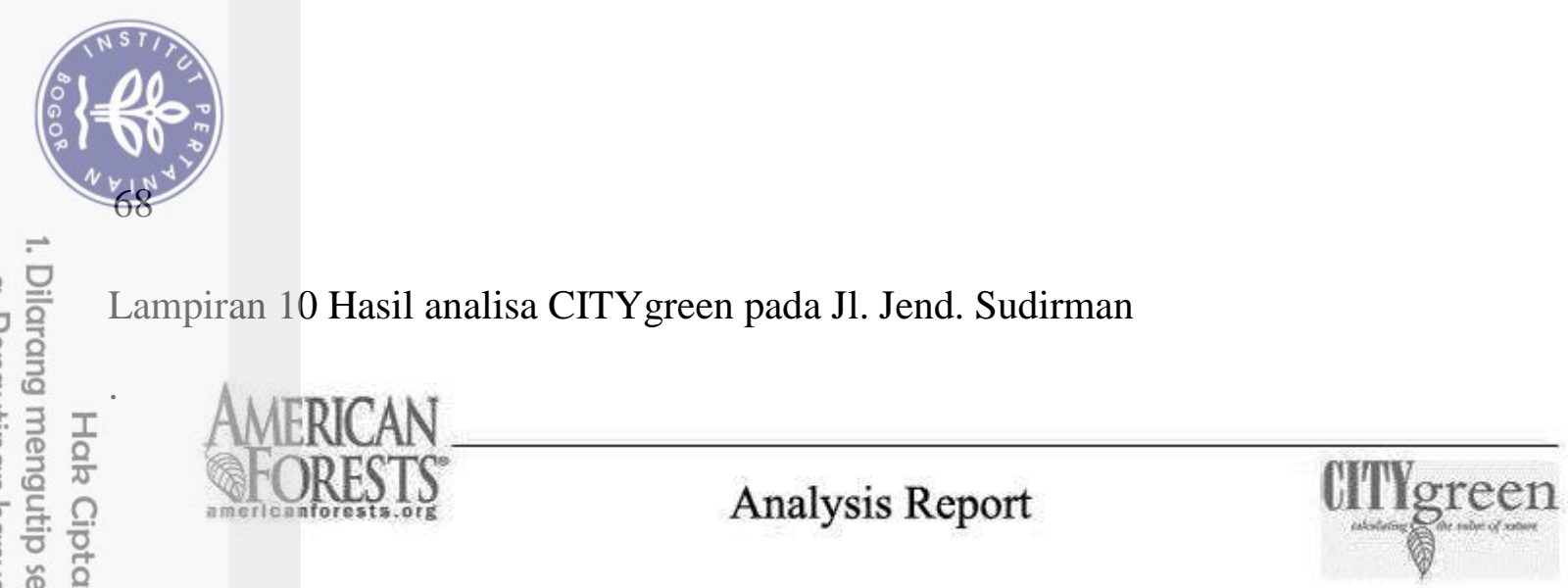

\section{$\underline{\text { Site Statistics }}$}

Analysis Area: Jalan Jend. Sudirman Scenario: Current Conditions Area:

0.02 sq. miles

13.72 acres

5.55 hectares
Landcover Distribution:

$0 \%$ Cropland

$40.59 \%$ Impervious

$0 \%$ OpenSpace/Pasture/Meadow

$0 \%$ Shrubs

$23.96 \%$ Tree Canopy

$42.30 \%$ Urban Land Use

$0 \%$ Water

Ecological Benefits

(20.7)

ir Pollution Removal

Air Quality Reference City Average - 10 Cities

Acres

0.00

5.57

0.00

0.00

3.29

5.80

0.00

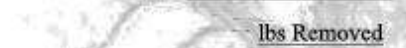

Sulfur Dioxide: Sulfur Dioxide:
Nitrogen Dioxide:

Particulate Matter:

Carbon Monoxide:

Total:

Total:

ooling Effects

Residdential Cooling Effect

Cast per Home:

Number or Homes:

(6) Savings from Trees:

을 Savings from Roofs:

$$
3 \text { Total Savings: }
$$

Savings per Home:

Kilowatt-hours Saved:

KWHs Saved per Home:

Carbon Generation Avoided:

Carbon Generation Avoided

per Home:

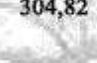

\section{lbs Removed}

$\begin{array}{r}105.41 \\ 35.37 \\ \hline\end{array}$

35.37
54.59

97.78

11.67

304,82

Dollar Value

$\$ 323,55$

$\$ 26,52$

$\$ 167,60$

$\$ 200,40$

$\$ 5,00$

$\$ 723,07$
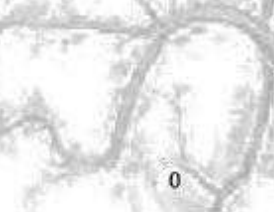

0

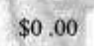

$\$ 0.00$

$\$ 0.00$

$\$ 0.00$

$\$ 0.00$

$\$ 0.00$

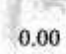

0.00

0.00 lbs.

$0.00 \mathrm{lbs}$.
Carbon Storage and Sequenstration Age Distribution of Trees: $\quad$ Average or Unknown Carbon Storage: $141.43-$ tons Carbon Sequestration: 1.10 pounds/year Stormwater Control Average 2-yr, 24-hour Rainfall: $\quad 0.50$ in Conditions: Current w/o trees* $\begin{array}{lcr}\text { Curve Number: } & 88.00 & 97.00 \\ \text { Runoff (in.): } & 0.03 & 0.26\end{array}$

Storage volume need to

mitigate the change in peak

flow:

$7,782.94$

cu. ft.

Construction cost:

$\$ 2.00$ per cu. ft.

Total

$\$ 15,565.88$

*Replaced by default landeover: Imperviouse Surface: Buildings/ structures: All other buildings

Economic Benefit Summary

Annual Air Pollution Removal Savings:

$\$ 723.07$

Annual Energy Savings:

Annual Stormwater Savings*:

Total Annual Savings:

$\$ 723.07$

-Annual stormwater savings is based on financing over 20 yaers at $6 \%$ 
Lampiran 11 Rincian penambahan pohon pada lokasi penelitian

\begin{tabular}{|c|c|c|}
\hline \multicolumn{3}{|c|}{ JL. Jalak Harupat } \\
\hline Nama Lokal & Nama Ilmiah & Penambahan Jumlah Tanaman \\
\hline Mahoni & Swietenia mahogani & 25 \\
\hline Kenari & Canarium commuane & 26 \\
\hline & TOTAL & 51 \\
\hline \multicolumn{3}{|c|}{ JL. Dadali } \\
\hline Nama Lokal & Nama Ilmiah & Penambahan Jumlah Tanaman \\
\hline Mahoni & Swietenia mahogani & 18 \\
\hline Bunga kupu-kupu & Bauhinia purpurea & 18 \\
\hline Pinus & Pinus merkusii & 7 \\
\hline Kènari & Canarium commuane & 18 \\
\hline$\underline{\Omega}$. & TOTAL & 61 \\
\hline
\end{tabular}

J) J. Ir. H. Djuanda

\begin{tabular}{|c|c|c|}
\hline Nama Lokal & Nama Ilmiah & Penambahan Jumlah Tanaman \\
\hline Māhoni & Swietenia mahogani & 8 \\
\hline Kē ari & Canarium commuane & 8 \\
\hline 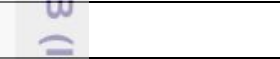 & TOTAL & 16 \\
\hline on & \multicolumn{2}{|c|}{ JL. Empang } \\
\hline Nama Lokal & Nama Ilmiah & Penambahan Jumlah Tanaman \\
\hline Kenari & Canarium commuane & 19 \\
\hline$\frac{11}{7}$ & TOTAL & 19 \\
\hline$\stackrel{20}{J}$ & \multicolumn{2}{|c|}{ JL. Jendral Ahmad Yani } \\
\hline Nama Lokal & Nama Ilmiah & Penambahan Jumlah Tanaman \\
\hline Mahoni & Swietenia mahogani & 11 \\
\hline Kênari & Canarium commuane & 12 \\
\hline Cemara gembel & Cupressus papuana & 11 \\
\hline & TOTAL & 34 \\
\hline
\end{tabular}

JL. Otto Iskandar Dinata

\begin{tabular}{llc}
\hline \multicolumn{1}{c}{ Nama Lokal } & \multicolumn{1}{c}{ Nama Ilmiah } & Penambahan Jumlah Tanaman \\
\hline Bungur & Langerstromia speciosa & 10 \\
Bunga kupu-kupu & Bauhinia purpurea & 10 \\
Kenari & Canarium commuane & 10 \\
\hline \multicolumn{3}{c}{ TOTAL } \\
\hline \multicolumn{1}{c}{ JL. Pemuda } \\
\hline Nama Lokal & Nama Ilmiah & Penambahan Jumlah Tanaman \\
\hline Mahoni & Swietenia mahogani & 12 \\
Kenari & Canarium commuane & 12 \\
Bunga kupu-kupu & Bauhinia purpurea & 12 \\
\hline \multicolumn{2}{c}{ TOTAL } & $\mathbf{3 6}$ \\
\hline
\end{tabular}

JL. R. E. Marthadinata 


\begin{tabular}{|c|c|c|c|}
\hline \multicolumn{2}{|r|}{ Nama Lokal } & \multirow{4}{*}{$\begin{array}{l}\quad \text { Nama Ilmiah } \\
\text { Canarium commuane } \\
\text { Bauhinia purpurea } \\
\text { Canarium commuane }\end{array}$} & \multirow{2}{*}{$\begin{array}{c}\text { Penambahan Jumlah Tanaman } \\
38\end{array}$} \\
\hline & Kenari & & \\
\hline & Bunga kupu-kupu & & 20 \\
\hline & Kenari & & 40 \\
\hline & & OTAL & 98 \\
\hline \multicolumn{4}{|c|}{ JL. Sudirman } \\
\hline \multicolumn{2}{|r|}{ Nama Lokal } & Nama Ilmiah & Penambahan Jumlah Tanaman \\
\hline & Bungur & Langerstromia speciosa & 23 \\
\hline & Mahoni & Swietenia mahogani & 33 \\
\hline & Kenari(○) & Canarium commuane & 30 \\
\hline \multicolumn{3}{|c|}{ TOTAL } & 86 \\
\hline & $\frac{2}{\lambda}$ & JL. Pajajar & \\
\hline \multicolumn{2}{|r|}{ NamafLokal } & Nama Ilmiah & Penambahan Jumlah Tanaman \\
\hline \multirow{2}{*}{\multicolumn{2}{|c|}{$\begin{array}{l}\text { Mahoni } \\
\text { Bunga ke ku-kupu }\end{array}$}} & Swietenia mahogani & 38 \\
\hline & & Bauhinia purpurea & 16 \\
\hline \multicolumn{2}{|r|}{ Kenari 릇 } & Canarium commuane & 20 \\
\hline & \multicolumn{2}{|c|}{ TOTAL } & 74 \\
\hline \multicolumn{3}{|c|}{ TOTAL KESELURUHAN } & 505 \\
\hline
\end{tabular}




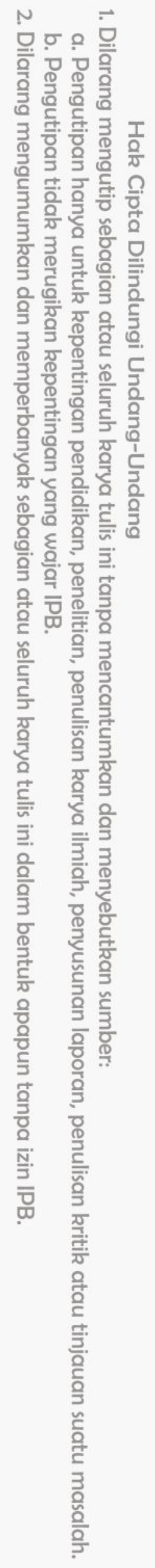

Lampiran 12 Daftar kode nama jalan sampel penelitian

\begin{tabular}{|c|c|c|}
\hline No & Kode & Nama Jalan \\
\hline 1. & DJN & JL. Ir. Juanda \\
\hline 2. & SDM & JL. Jendral Sudirman \\
\hline 3. & PMD & JL. Pemuda \\
\hline 4. & PDJ & JL. Raya Pajajaran \\
\hline 5. & JAL & JL. Jalak Harupat \\
\hline 6. & REM & JL. R.E Martadinata \\
\hline 7.( () & $\mathrm{AHN}$ & JL. Ahmad Yani \\
\hline 8. & OTS & JL. Otto Iskandardinata \\
\hline 9. $\frac{\frac{1}{2}}{\frac{\pi}{2}}$ & EMP & JL. Raya Raya Empang \\
\hline 10. & DDL & JL. Dadali \\
\hline
\end{tabular}


Lampiran 13 Daftar kode nama lokal pohon sampel penelitian

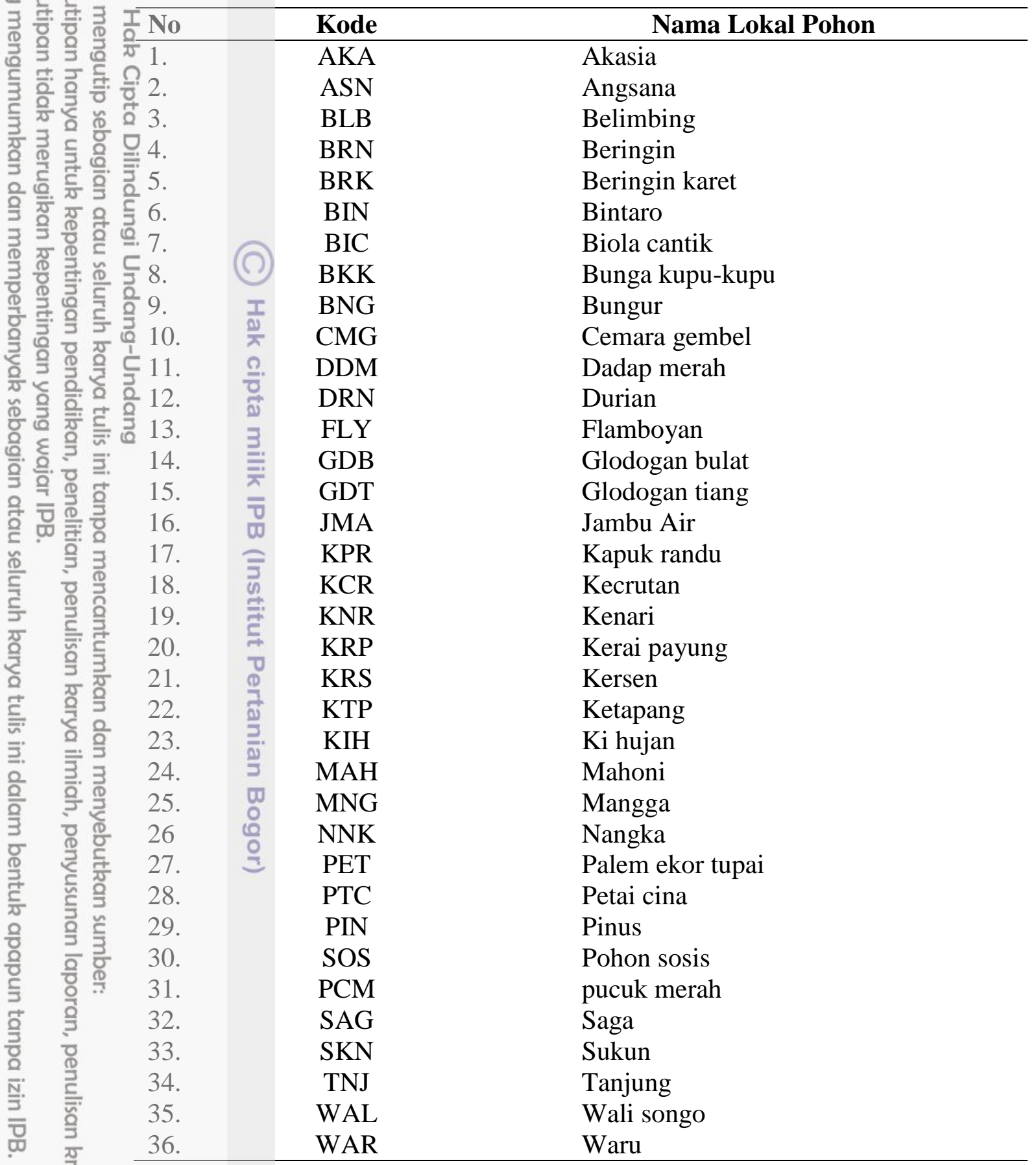

BIN

BKK

$\mathrm{CMG}$

DRN

FLY

JMA

$\mathrm{KCR}$

KNR

KRS

KTP

$\mathrm{MNG}$

PTC

PIN

PCM

WAL

Waru 


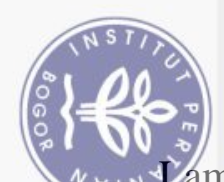

vin Jampiran 14 Peta lokasi penambahan vegetasi pada Jl. Jalak Harupat

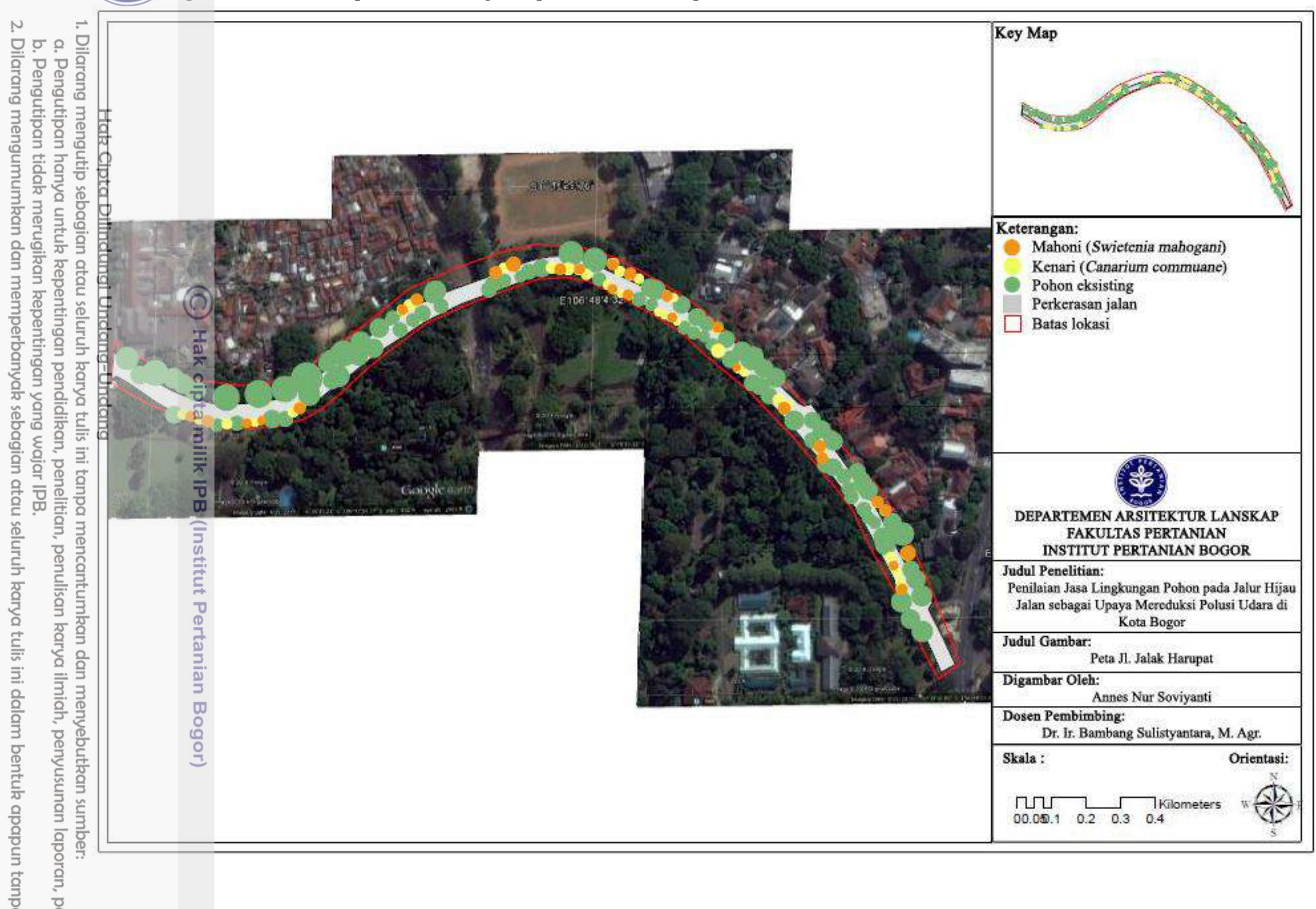




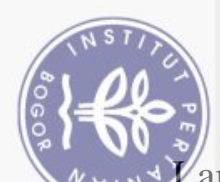

68
Lampiran 15 Peta lokasi penambahan vegetasi pada Jl. Dadali

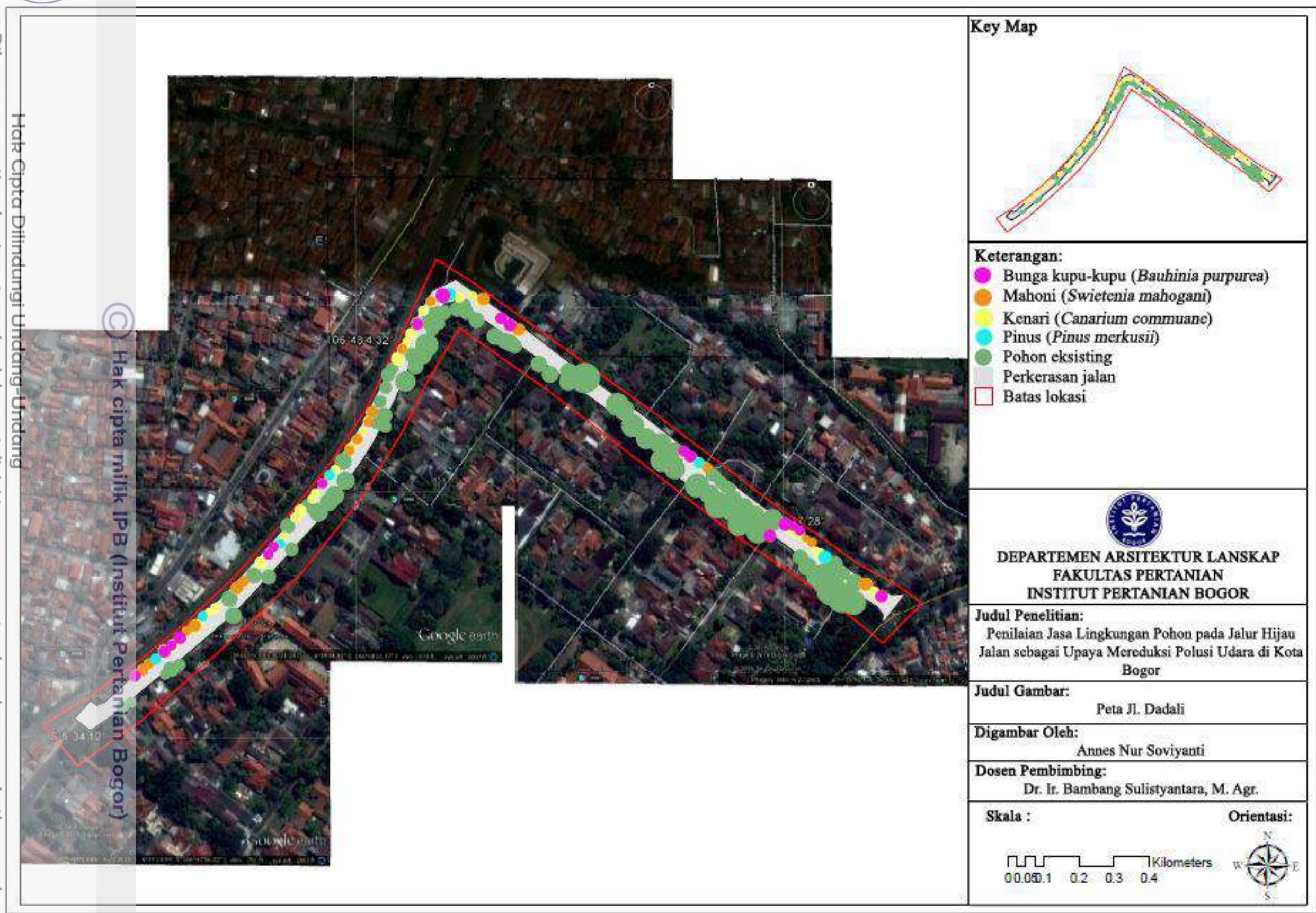




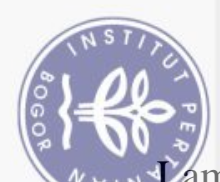

Nin Lampiran 16 Peta lokasi penambahan vegetasi pada J1. Ir. H. Djuanda

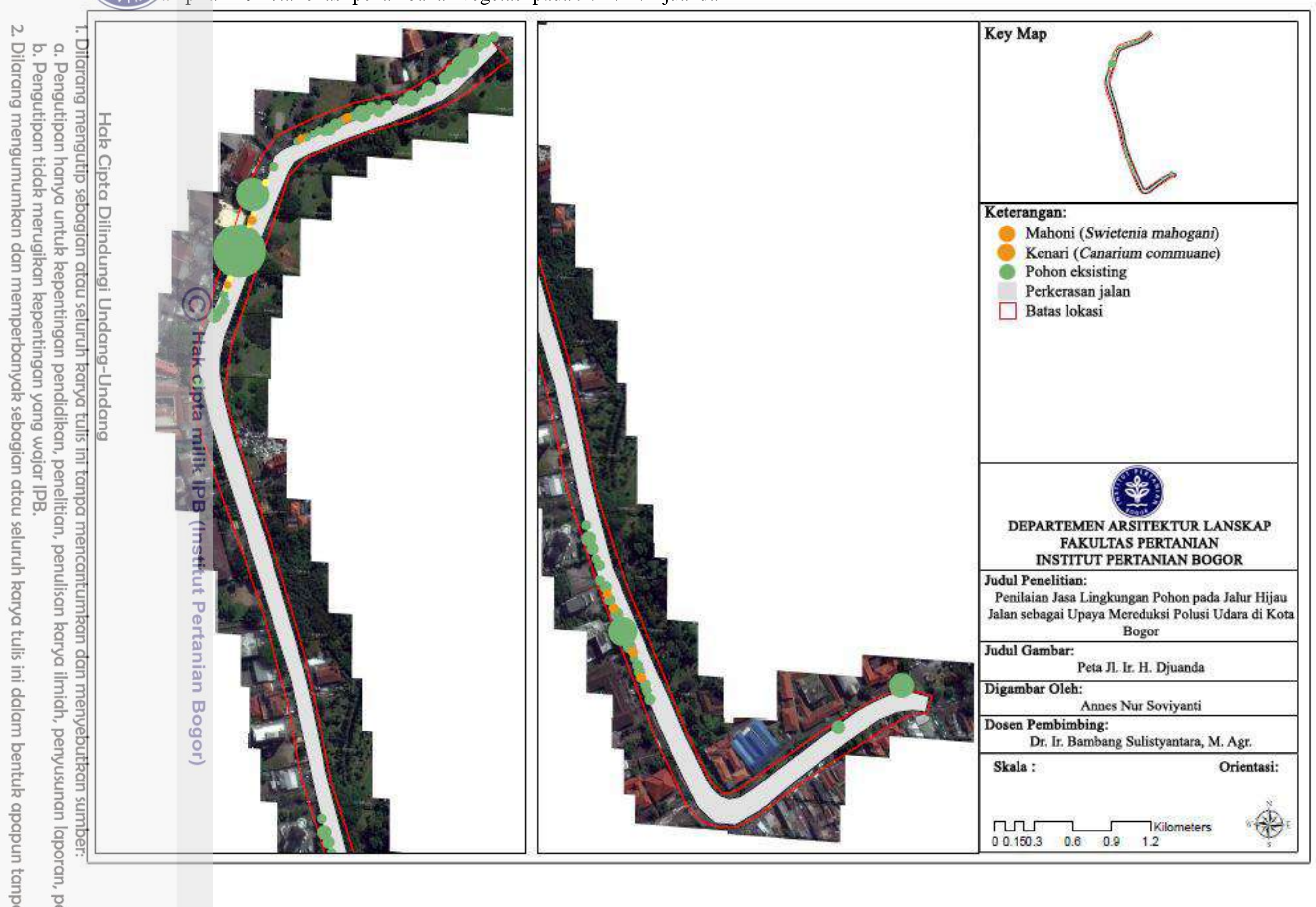




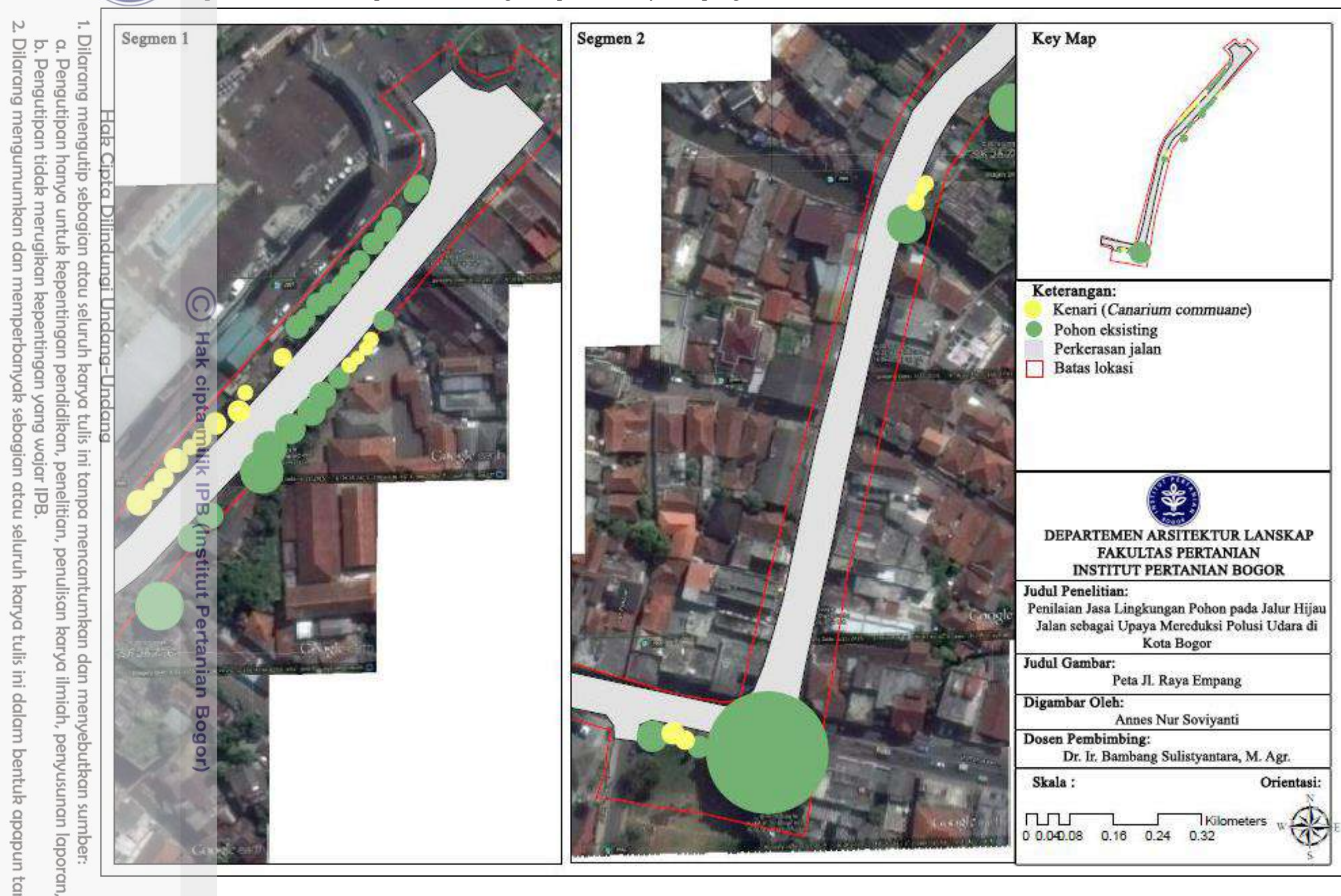




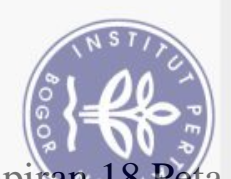

Lampiran 18. Péta lokasi penambahan vegetasi pada Jl. Jendral Ahmad Yani

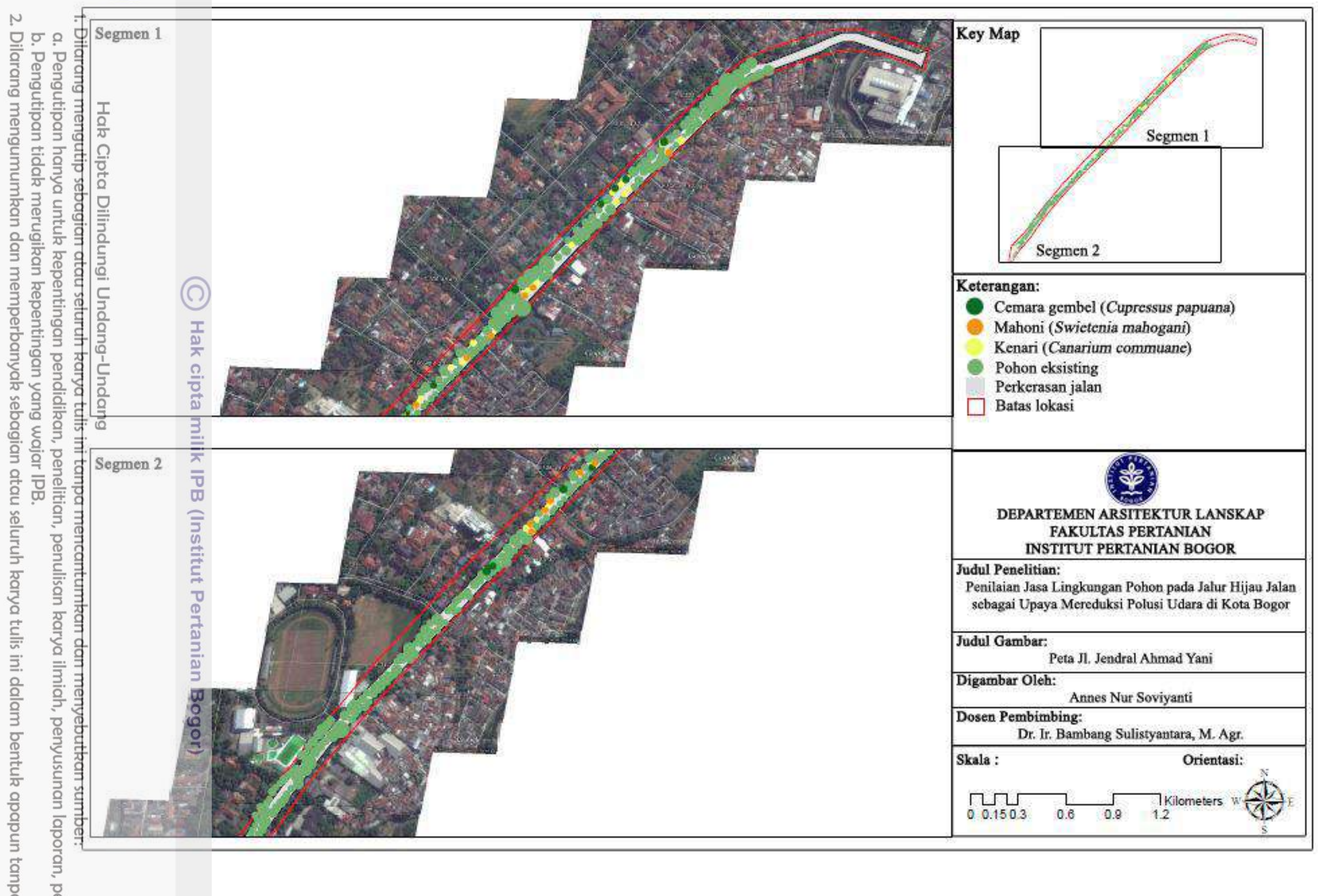




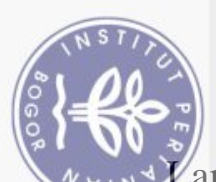

72 Lampiran 19 Peta lokasi penambahan vegetasi pada Jl. Otto Iskandar Dinata

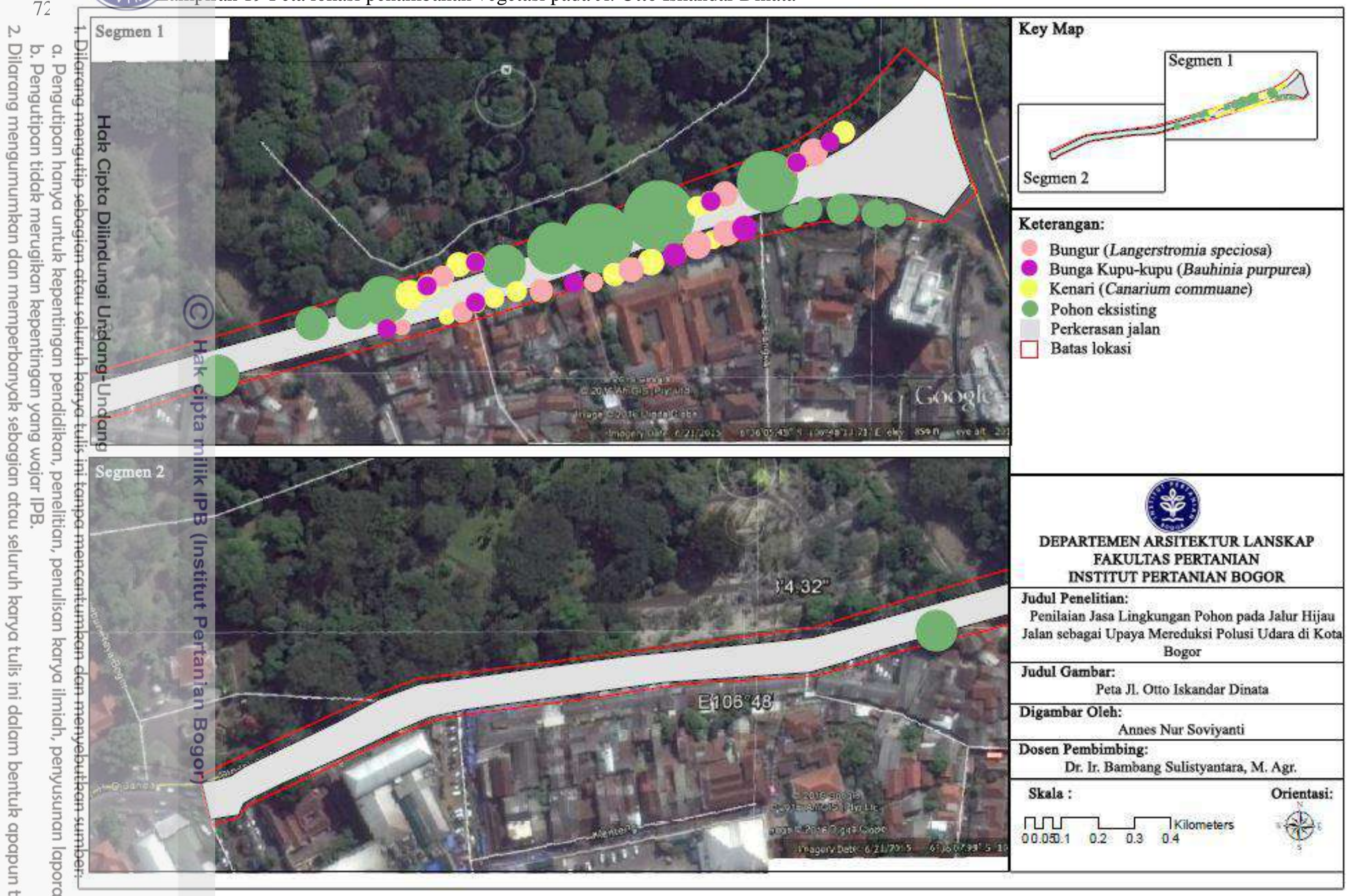




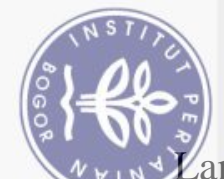

Nun Lampiran 20 Peta lokasi penambahan vegetasi pada Jl. Pemuda

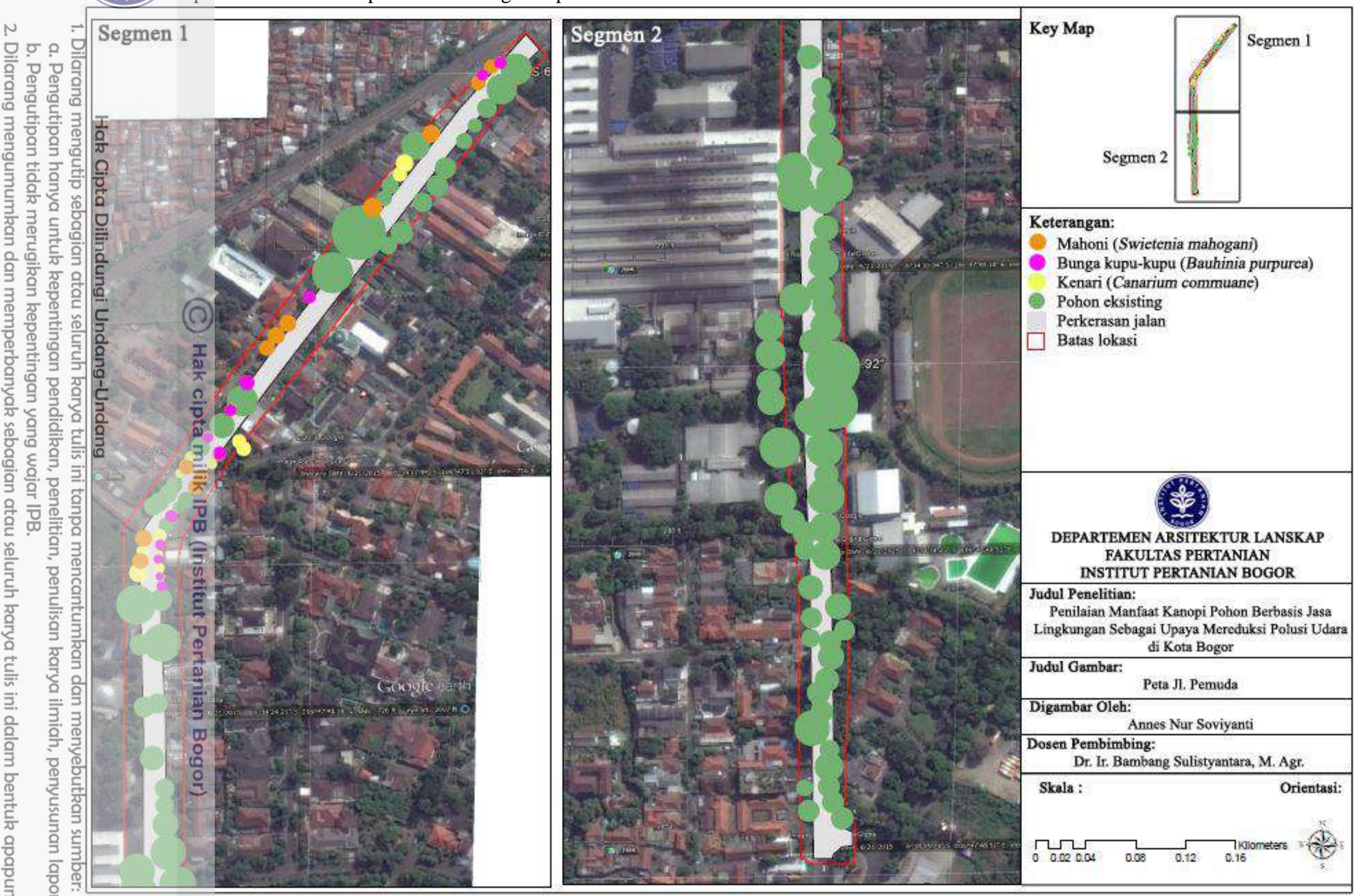


74

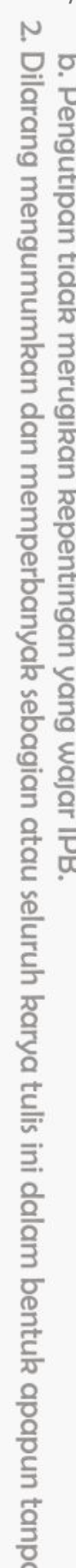

Lampiran 21 Peta lokasi penambahan vegetasi pada Jl. R.E. Martadinata
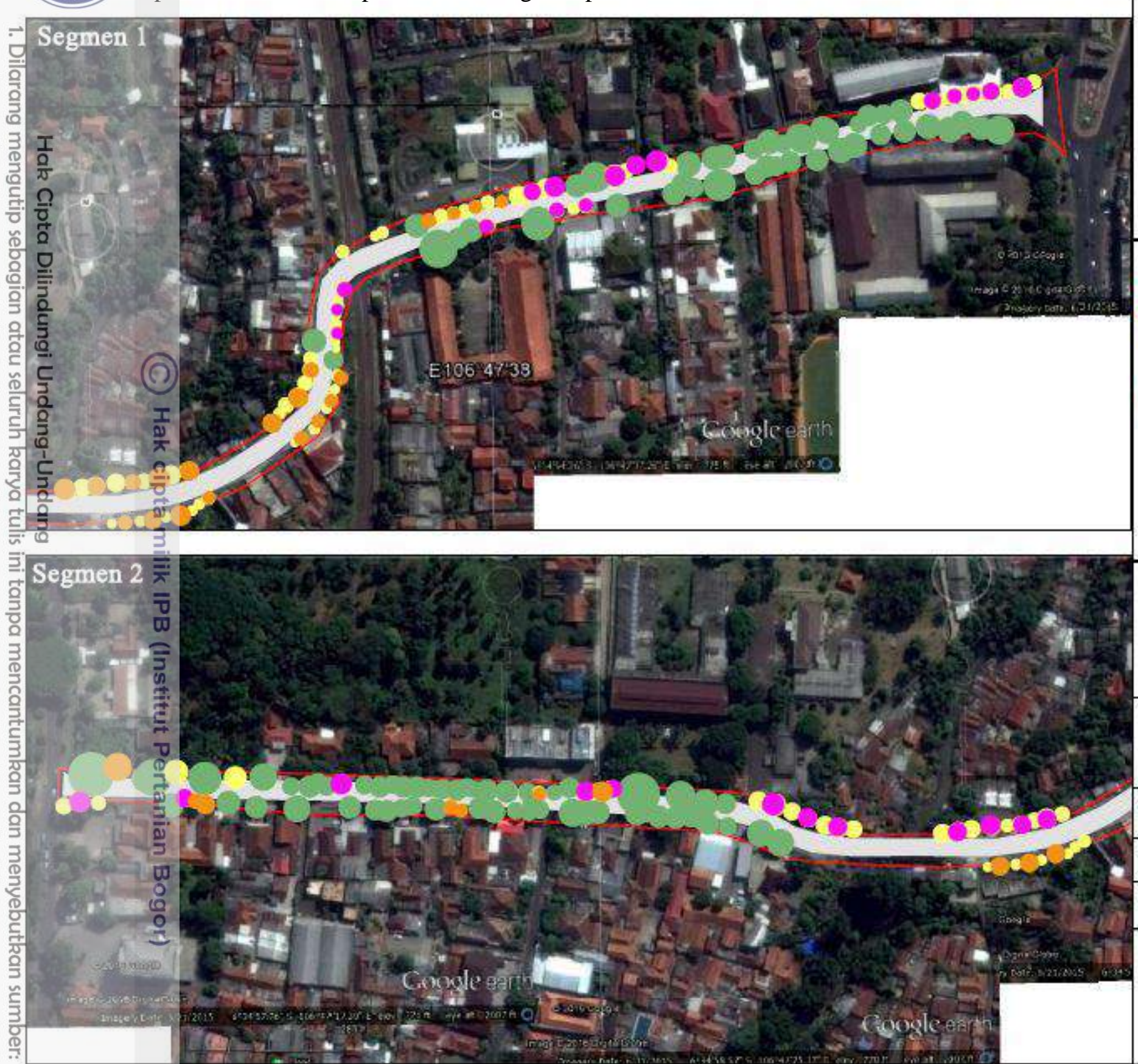

Key Map

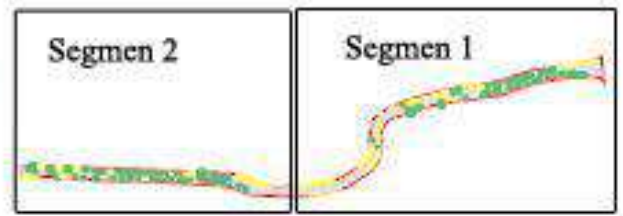

Keterangan:

Mahoni (Swietenia mahogani)

Bunga kupu-kupu (Bauhinia purpurca)

Kenari (Canarium commuane)

Pohon eksisting

Perkerasan jalan

Batas lokasi
DEPARTEMEN ARSITEKTUR LANSKAP FAKULTAS PERTANIAN INSTITUT PERTANIAN BOGOR

Judul Penelitian:

Penilaian Jasa Lingkungan Pohon pada Jalur Hijau Jalan sabagai Upaya Merudukasi Polusi Udara di Judul Gambar: Kota Bogor

Peta J. R.E. Martadinats Annes Nur Soviyanti Dosen Pembimbing:

Dr. Ir. Bambang Sulistyantara, M. Agr. Skala : Orientasi:

ॠऍ $\longrightarrow$ Kilometers $\begin{array}{lllllllllll}00.06 .1 & 0.2 & 0.3 & 0.4\end{array}$ 


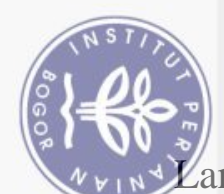

Wampiran 22 Peta lokasi penambahan vegetasi pada Jl. Jendral Sudirman
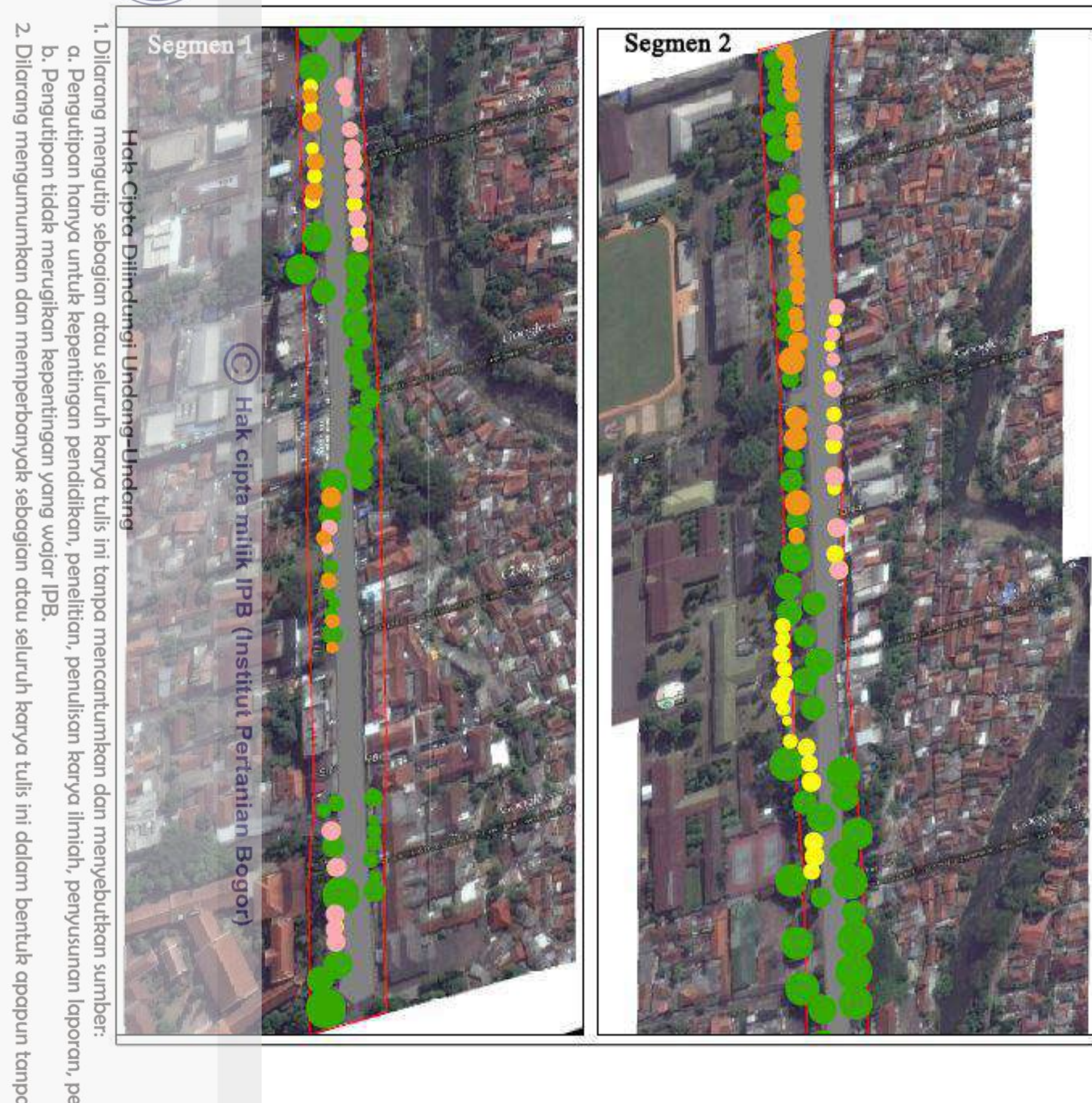

Key Map

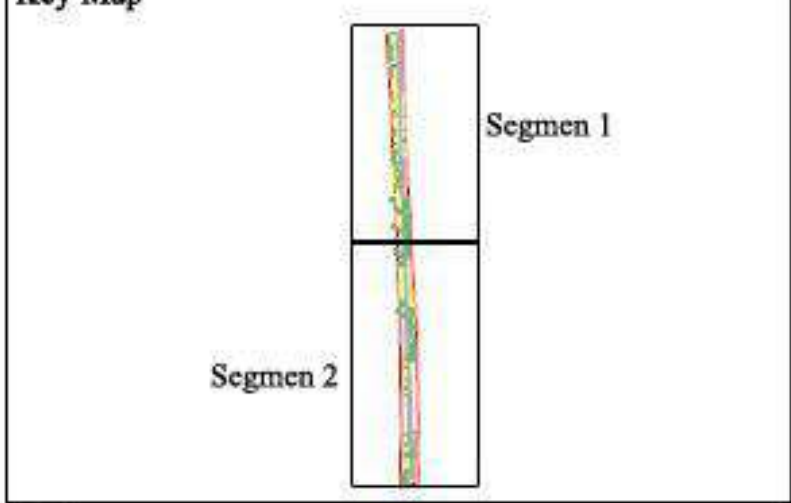

\section{Keterangan:}

(9ungur (Langerstromia speciosa)

- Mahoni (Swietenia mahogani)

Kenari (Canarium commuane)

Pohon eksisting

Perkerasan jalan

$\square$ Batas lokasi

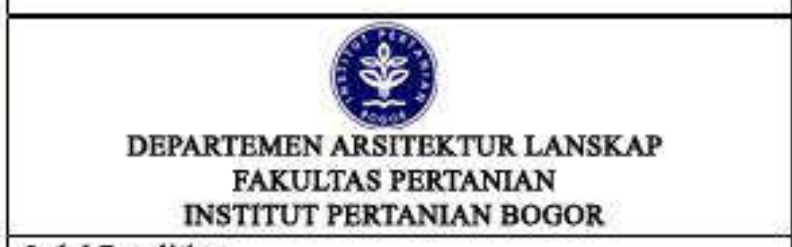

Judul Penelitian:

Penilaian Jasa Lingkungan Pohon pada Jalur Hijau Jalan sabagai Upaya Merudukasi Polusi Udara di Kota Bogor

Judul Gambar:

\begin{tabular}{|c|c|c|c|c|}
\hline \multicolumn{5}{|c|}{ k k } \\
\hline \multicolumn{5}{|c|}{ Digambar Oleh: } \\
\hline \multicolumn{5}{|c|}{$\begin{array}{l}\text { Dosen Pembimbing: } \\
\text { Dr. Ir. Bambang Sulistyantara, M. Agr. }\end{array}$} \\
\hline Skala: & & & & Orientasi: \\
\hline$\prod_{0.020 .04}$ & 0.08 & $\longdiv { 0 . 1 2 }$ & $\begin{array}{l}\text { Thilometers } \\
0.16\end{array}$ & \\
\hline
\end{tabular}




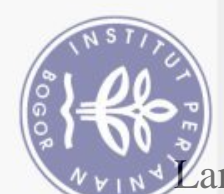

76

Lampiran 23 Peta lokasi penambahan vegetasi pada Jl. Pajajaran Segmen 1 dan 2

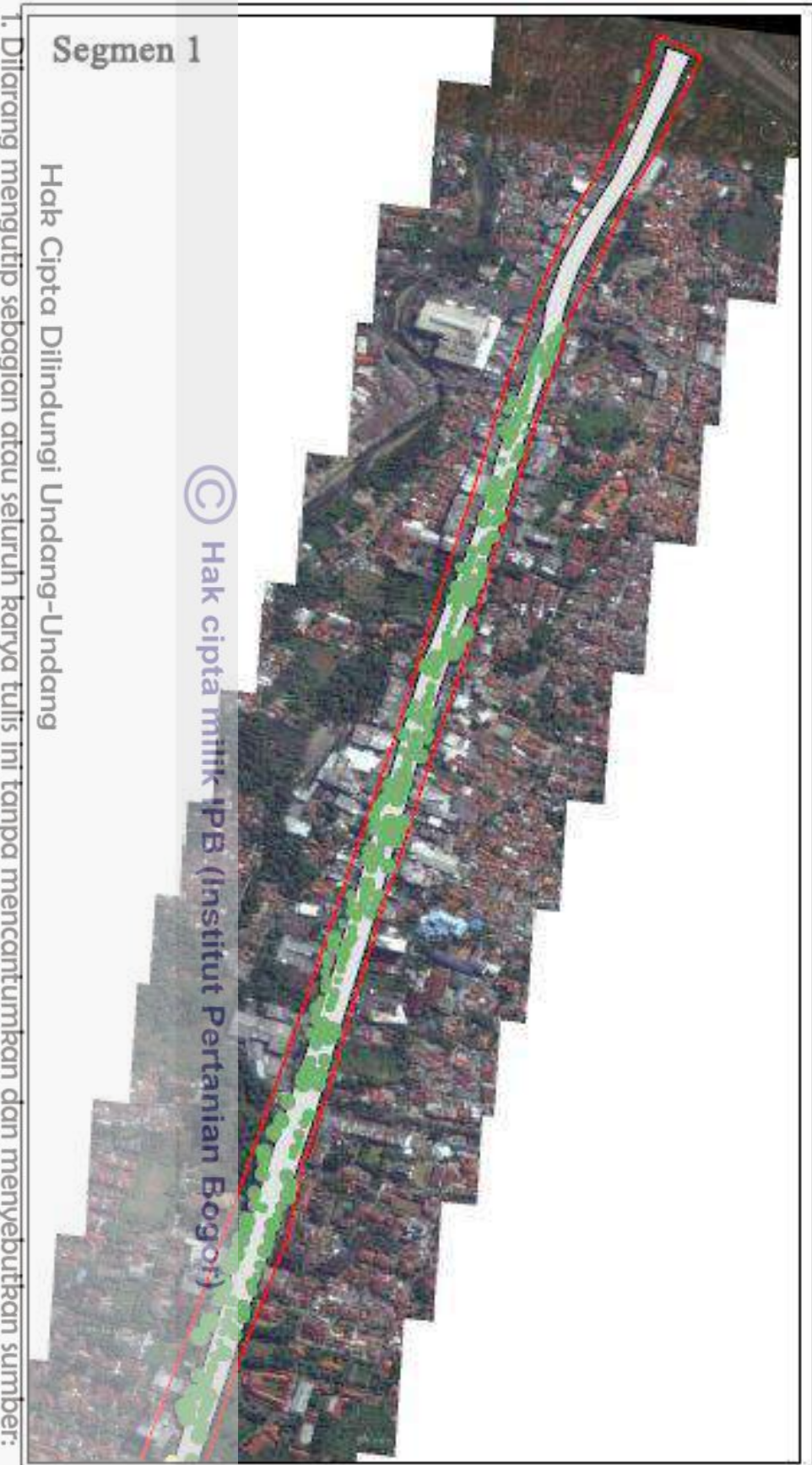

Segmen 2
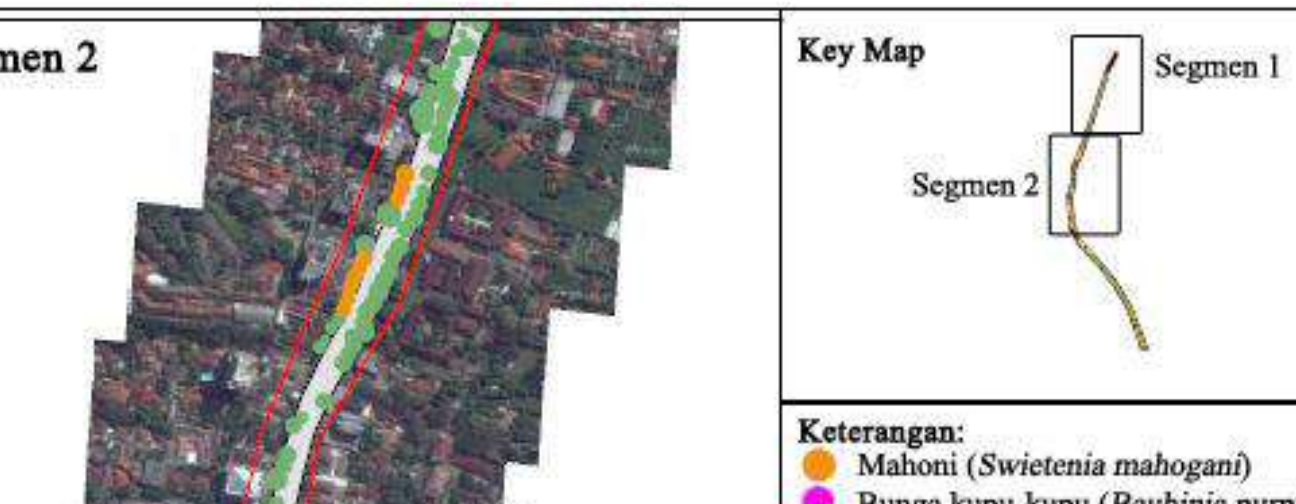

Keterangan:

Mahoni (Swietenia mahogani)

- Bunga kupu-kupu (Baubinia purpurea)

Kenari (Canarium commuane)

Pohon eksisting

Perkerasan jalan

$\square$ Batas lokasi

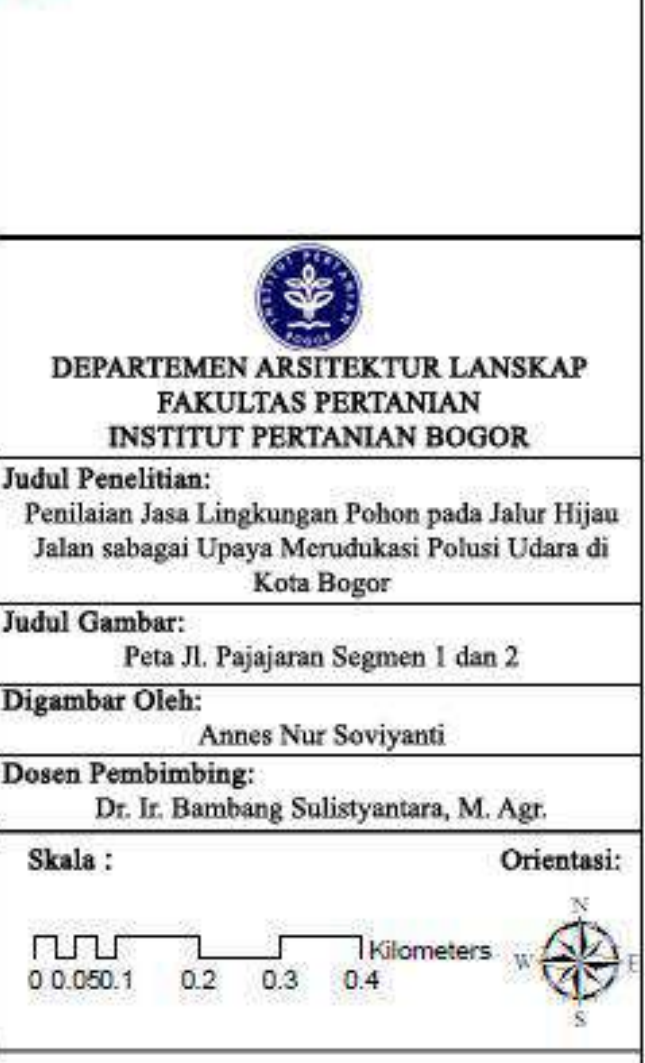




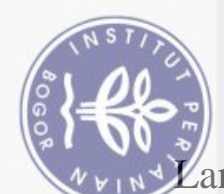

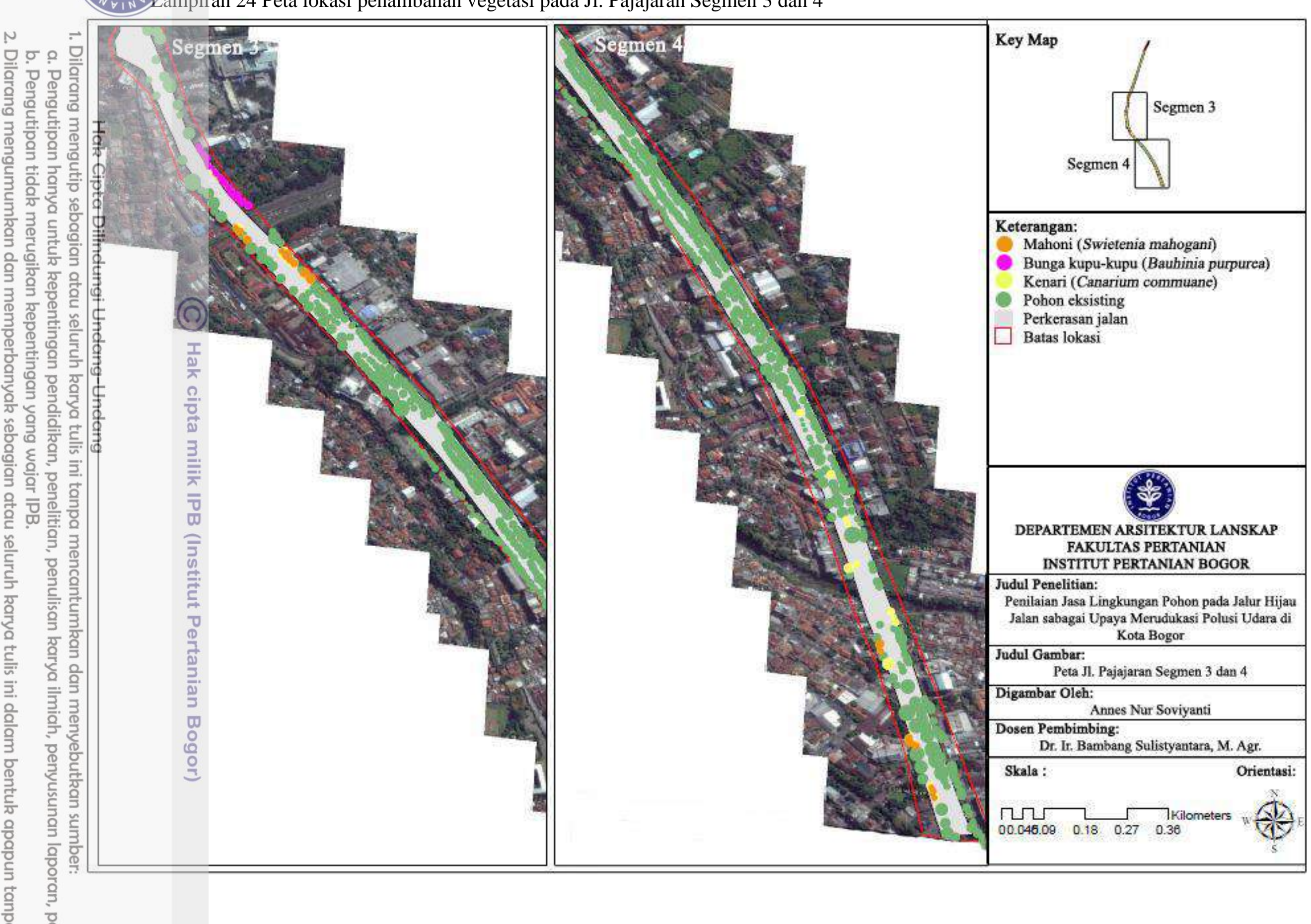




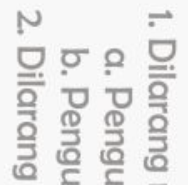

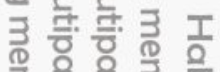

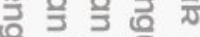

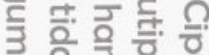

这尔造

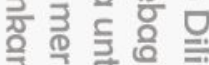

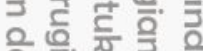

을 젱의

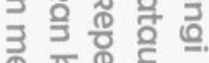

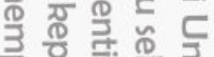

잉

공 롴을 동 을

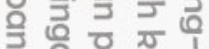

잉율 익

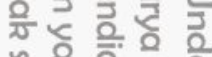

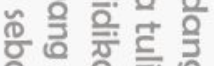

응 을

흘 응. 킁.

윽 웅

융 亩旁

๕

들

于 产

쫄 ฏ을

쟁

를

촐 을

을. 궁

을 흘 올

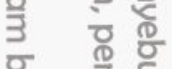

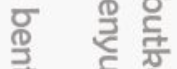

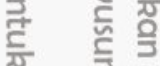

융 을

응 응 항

을

읭

흥 임

N.ㄱ: 产

ㅁํํ ํํำ

হू্ত

O

융

志

(8)

윽

흐

(อ)

공

등

흑 


\section{RIWAYAT HIDUP}

Penulis dilahirkan pada hari Jum'at tanggal 9 Oktober 1992 di Bogor, Jawa Barat. Penulis merupakan anak kedua dari 2 (dua) bersaudara dari pasangan Ma'ruf dan Tini Suarti.

Penulis menyelesaikan pendidikan Taman Kanak-kanak hingga Sekolah Dasar di Citayam, Kabupaten Bogor, pada tahun 2006 di Taman Kanak-kanak Atsiri Permai, dan Sekolah Dasar Swasta Pelita Citayam, kemudian menyelesaikan pendidikan Sekolah Menengah Pertama hingga Sekolah Menengah Atas di Kota Bogor pada tahun 2011 di SMP Negeri 2 Bogor, dan SMA Negeri 3 Kota) Bogor. Pada tahun yang sama penulis diterima di Institut Pertanian Bogor (IPB) melalui jalur SNMPTN (Seleksi Nasional Masuk Perguruan Tinggi Negeri) di Departemen Arsitektur Lanskap, Fakultas Pertanian, Institut Pertanian Bogor. Penqlis berlasil menyelesaikan program Minor Konservasi Sumber Daya Hayati dan Manajemen Rekreasi Alam yang disediakan oleh Departemen Konservasi Sumberdaya Hutan dan Ekowisata.

Penulis menjadi pengurus HIMASKAP (Himpunan Mahasiswa Arsitektur Lans $\underline{\underline{\underline{S}}}$ kap) selama 2 periode, periode pertama pada tahun 2012-2013, dan periode ke ఫृua pada tahun 2013-2014, menjabat sebagai sekretaris divisi PSDM (Pengembangan Sumber Daya Manusia). Selain kegiatan di Himpunan Mahasiswa penalis juga mengikuti organisasi kewirausahaan yang digagas oleh CDA (Career Development Alumni) IPB dan Ikatan Almumni Fakultas Pertanian (IKA FAPERTA) yaitu Sabisa Farm IPB Generasi Ke 2 yang dilakukan selama satu tahuh sejak 2015 hingga 2016.

Penulis mengabdikan dirinya sebagi Asisten mata kuliah Penanaman Lansk ap (ARL 322) pada tahun 2014-2015 dengan Koordinator Mata Kuliahnya adafah Dr. Ir. Nizar Nasrullah, M.Agr, dan Mata kuliah Teknik Studio (ARL 210) padg tahun 2015-2016 dengan Koordinator Mata kuliahnya adalah Dr. Ir. Bambang Sulistyantara, M.Agr. Penulis berhasil menyelesaikan penelitian yang berjudul "Penilaian Jasa Lingkungan Kanopi Pohon pada Jalur Hijau Jalan sebagai Upaya Mereduksi Polusi Udara Di Kota Bogor" sebagai syarat menjadi sarjana pertanian dibawah bimbingan Dr. Ir. Bambang Sulistyantara, M.Agr. 